\title{
A Review of Research on the Growth of Multinational Enterprises: A Penrosean Lens
}

\author{
Danchi Tan*1 \\ Professor of International Business \\ Department of International Business \\ National Chengchi University \\ 64, Chih-nan Rd., Sec. 2, Wenshan, Taipei 11623, Taiwan \\ dctan@,nccu.edu.tw \\ Weichieh Su \\ Associate Professor of International Business \\ Department of International Business \\ National Chengchi University \\ 64, Chih-nan Rd., Sec. 2, Wenshan, Taipei 11623, Taiwan \\ weichieh@nccu.edu.tw \\ Joseph T. Mahoney \\ Caterpillar Chair of Business \\ Professor of Strategy, Entrepreneurship, and International Business \\ Gies College of Business \\ University of Illinois at Urbana-Champaign \\ 140C Wohlers Hall, 1206 South Sixth Street, Champaign, IL 61820 \\ 217-244-8257 \\ josephm@illinois.edu \\ Yasemin Kor \\ Beckwith Chair of Management Studies \\ Judge Business School \\ University of Cambridge \\ Trumpington Street, Cambridge, CB2 1AG, UK \\ y.kor@jbs.cam.ac.uk
}

Acknowledgements: The authors are grateful to Area Editor Becky Reuber and three anonymous reviewers for their valuable comments and suggestions. The authors also thank Klaus Meyer for helpful comments on the earlier version of the proposal for the review article.

\footnotetext{
* Corresponding author: dctan@nccu.edu.tw.

${ }^{1}$ Authors are listed in reverse alphabetical order. All authors have contributed equally to the paper.
} 


\title{
A Review of Research on the Growth of Multinational Enterprises: A Penrosean Lens
}

\begin{abstract}
We provide a comprehensive review of the growth of multinational enterprises (MNEs) based on a quartercentury ( 25 years) of scholarly international business publications. We synthesize research insights on the determinants of the growth of MNEs through the lens of Penrose's theory of firm growth, which is the most influential theoretical perspective on firm growth. The review takes stock of the research findings on the facilitators, constraints, and the trajectory of growth of MNEs, and elaborates on the commonalities and differences between research on the growth of MNEs that draws on Penrose's theory and research that does not. This comparison highlights the opportunity to build an internally coherent theory of the growth of MNEs, that is, a theory that connects 'what an MNE is' to 'what determines an MNE's growth.' It also indicates that past research placed a strong emphasis on exogenous factors (e.g., cross-country distances) as key constraints on growth even though the Penrosean lens suggests a close consideration of endogenous factors that drive international growth, as well as endogenizing the ostensibly exogenous growth determinants. The review highlights the importance of firm-specific managerial knowledge and learning, which shapes the direction of the growth of MNEs and ensures its administrative coherence.
\end{abstract}

Keywords: growth; international business; multinational enterprises (MNEs); Edith Penrose 


\section{INTRODUCTION}

Growth is a fundamental concept in the research related to multinational enterprises (MNEs). In mainstream international business (IB) research, such as research on the entry into foreign markets and the internationalization processes, growth is essentially an implicit corporate objective, although some studies have focused explicitly on the growth of MNEs (Belderbos \& Zou, 2007; Hutzschenreuter, Voll, \& Verbeke, 2011; Tan, 2009). International expansion involves the corporate-level decision to pursue profitable growth in foreign markets (Buckley \& Casson, 2007; Meyer, 2006). The growth of MNEs is manifested by sequential expansion of their subsidiaries in existing host countries as well as their entries into other countries. Since growth constitutes "an evolutionary process" (Penrose, 1995: xiii), research on divestments and exits of MNEs also contributes to our understanding of the growth trajectory of multinational firms.

In this review paper, we synthesize research insights on the determinants of the growth of MNEs through the lens of Edith Penrose's (1959) seminal book, The Theory of the Growth of the Firm ${ }^{2}$, to develop a more coherent and comprehensive understanding of research on the growth of MNEs and envision opportunities for future research. We chose Penrose (1959) as a guiding framework in our review because her theory is the most influential reference (highest citation count) in management research on the growth of firms (Zupic \& Drnovsek, 2014). The IB research community also has recognized the importance of Penrose's work. ${ }^{3}$ Penrose was the second scholar to receive the John Fayerweather Eminent Scholar Award given by the Academy of International Business fellows. Prominent IB scholars, including Buckley, Casson, Dunning, Pitelis, Teece, and Verbeke, have shown that Penrose's (1959) insights on the nature of the firm and its growth have implications for MNE research. Her work also influenced the development of the influential internationalization process model (Vahlne \& Johanson, 2017). Although Penrose's work, especially her conceptualization of a firm as a collection of productive resources, has

\footnotetext{
2 Penrose did not apply her work on explaining the growth of MNEs (Kay, 1999; Pitelis, 2002, 2009), although she did mention briefly that her theory of the growth of the firm "seems by and large to apply equally well to expansion by direct foreign investment in its modern form" (1995: xv).

${ }^{3}$ Forty-three articles (i.e., 22\%) in our sample cite Penrose's work at least once, and some of these studies base their theory development directly on Penrose's (1959) theory as a (disequilibrium) process theory of firm growth (particularly research on the growth trajectory of the MNE). Her impact in general management discipline is quite prominent, as a recent bibliometric analysis of over 400 management studies shows that Penrose' work is the most cited reference on the growth of firms (Zupic \& Drnovsek, 2014). Moreover, as of March 1, 2020, Penrose (1959) had over 35,000 citations based on Google Scholar.
} 
been extended to resource- and capability-based theories of firms, these theories focus primarily on the characteristics of resources and capabilities to explain and predict the heterogeneity of firm-level performance. Yet, at the center of Penrose's (1959) theory is the profitable growth of the firm (Augier \& Teece, 2007; Kor \& Mahoney, 2000, 2004; Rugman \& Verbeke, 2002). Penrose's attention to the drivers, constraints, and processes of growth provides a framework for organizing and synthesizing the various determinants found in research on the growth of MNEs. Resource-based and in particular dynamic capabilities approaches (Teece, 2014) also offer important insights about how versatile resources and (dynamic) capabilities of firms can enable them to achieve long-term profitable growth in fast-paced changing environments. Thus, we take note of these insights in our review of firmspecific resources as facilitators of the growth of MNEs.

We submit that taking stock of research related to the growth of MNEs with a framework inspired by Penrose's growth theory can enable scholars to make better sense of the accumulated research insights, which are rich but remain scattered across different studies with different theoretical roots, levels of analysis (e.g., firm vs. subsidiary growth), and national contexts. With a focus on the facilitators, constraints, and processes of a firm's growth, this framework facilitates the organization and synthesis of the insights, which then can guide new research on the growth of MNEs.

In addition, this review provides an opportunity to elaborate on the similarities and differences between research on the growth of MNEs that draws on Penrose's growth theory and research that does not. This comparison enables us to reflect on concepts and ideas that have not been examined thoroughly in the research related to the growth of MNEs. One of these under-examined ideas is firm-specific managerial learning. Even though the extant research regularly cites Penrose's (1959) conceptualization of the firm as a unique bundle of resources, it often neglects the idea that managerial choices shape the productive services of resources, and the interactions between managers and resources jointly drive the growth of firms. Thus, managerial knowledge about the firm's unique resources or firm-specific managerial learning can contribute to the creation of new productive resources that facilitate international growth. Our review of research on the growth of MNEs suggests that this research has emphasized the role of host-country knowledge while giving insufficient attention to firm-specific managerial knowledge and learning. However, for an MNE, either as a hierarchy (administrative organization) that relies on 
managers to allocate resources (Buckley \& Casson, 1976; Hennart, 1982) or as a group of geographically dispersed and goal-disparate organizations (Ghoshal \& Bartlett, 1990), firm-specific managerial knowledge can be crucial in maintaining organizational coherence (Teece, Rumelt, Dosi, \& Winter, 1994). Such firm-specific knowledge and organizational coherence are needed for effective coordination and knowledge transfer (Cantwell, Dunning, \& Lundan, 2010), and for curbing managerial opportunism (Hoenen \& Kostova, 2015) as part of the successful pursuit of long-term profitable growth for the overall MNE.

This comparison also allows scholars to consider developing an internally coherent theory of the growth of MNEs, which connects 'what an MNE is' to 'what determines an MNE's growth.' Penrose and dominant foreign direct investment (FDI) theories (Buckley \& Casson, 1976; Hennart, 1982) share a similar notion of firms as administrative organizations that rely on managers to allocate resources. In Penrose's theory, 'what a firm is' explains 'how the firm grows,' and the underpinning logic derives the necessary and sufficient conditions for growth as well as its constraints. However, in IB research, discussions on how 'an MNE functions' and 'how an MNE grows' are in different streams of research. This separation results in an incomplete understanding of the process by which an MNE grows as an administrative organization.

Finally, Penrose (1959) offers an endogenous growth model in which growth determinants are generated internally, and the external environment is perceived subjectively and could be strategically influenced by managerial actions. While MNE research recognizes some of the endogenous aspects of profitable growth (such as experiential learning in foreign markets), it places a strong emphasis on exogenous factors, such as cross-country distances, as key constraints on growth. Our review highlights research opportunities based on a close consideration of endogenous factors that drive international growth, as well as endogenizing some of the ostensibly exogenous growth determinants.

The next section provides an overview of Penrose's theory of the growth of the firm to develop a framework for organizing our review of research on the growth of MNEs. Next, we explain our review methodology and present our review and synthesis of the literature through a Penrosean lens. Then, in connection with the review and research gaps we identified, we offer our suggestions for new directions for future research. 


\section{PENROSE'S GROWTH THEORY}

In Penrose's (1959) theory, the determinants of the growth of the firm derive from a conceptualization of the firm and its objective. Thus, we summarize the theory in terms of (1) the nature of a firm, (2) the objective of the firm, (3) the (facilitating and constraining) determinants of the growth of the firm, and (4) the growth trajectory of the firm.

What is a firm? In Penrose's (1959) theory, a firm is an administrative organization that requires managerial decision-making (Barnard, 1938; Simon, 1947). However, as Penrose elaborates, "a firm is... also a collection of productive resources the disposal of which between different uses and overtime is determined by administrative decision" (1959: 24). This conceptualization of a firm offers a foundation for firm heterogeneity based on the firm's bundle of resources and the central role of managers in shaping and utilizing these resources. Specifically, managers act as catalysts in converting a firm's resources into productive services (Mahoney, 1995) through decisions on resource development, deployment, utilization, and combination. We note that Penrose's conceptualization of a firm, as an administrative organization, is similar to international business (IB) research on internalization theory. In particular, the use of authority or managerial fiat to organize exchanges is the raison d'être for multinational firms and what distinguishes them from market mechanisms (Buckley \& Casson, 1976; Hennart, 1982).

What is the objective of the firm? Penrose submits that the objective of the firm is long-term growth through investing in profitable expansion (1959: 29). Because a firm is not confined to particular products or locations, "there are opportunities for profitable investment open somewhere in the economy" (1959: 43). Penrose offers product diversification as a solution for unfavorable external conditions, and, in this vein, a firm's entry into new foreign markets also can be a profitable growth solution to stagnant home and host markets. Therefore, new foreign entries, along with subsequent growth in existing host markets, constitute the MNE's overall growth.

What facilitates the growth of the firm? Penrose maintains that the growth of the firm is derived from internal facilitators, which include underutilized firm resources, innovation, and managerial learning. She posits that, as long as current operations do not fully utilize productive resources, "there is an incentive for a firm to find a way of using them more fully" (1959: 67). In Penrose's theory, what makes resources underutilized is their indivisibility (e.g., lumpy physical capital) and fungibility (Augier \& Teece, 2007), as well as 'resource learning' 
(the creation of new knowledge) during ongoing operations of the firm (1959: 69). These underutilized resources facilitate further innovation as managers experiment with new resource combinations to more fully and productively utilize existing resources through the growth of the firm (1959: 86).

Managerial learning also is an important driver of the growth of firms. Learning increases and enriches managers' tacit knowledge about the bundle of resources in the firm, which in turn expands the range of productive services from those resources (1959: 5). Thus, the growth of a firm is a dynamic process of management interacting with resources (Kor, Mahoney, Siemsen, \& Tan, 2016). In addition, Penrose considers managers' entrepreneurial capabilities as crucial for the firm's growth (1959: 8). Entrepreneurial capabilities consist of the ability to shape creative imagination and vision for the firm (1959: 36), the ability to create confidence in investors (1959: 38), and the ability to develop and utilize information-gathering and consulting facilities that enable managers to evaluate and manage risk and uncertainty in different growth directions (1959: 41). These capabilities enable firms to continue to create or discover new markets to utilize their resources fully.

What constrains the growth of the firm? Penrose emphasizes that the binding constraint on the profitable growth of a firm arises from the need for managers to accumulate firm-specific knowledge, which is essential for formulating and implementing growth plans. However, it takes time for managers to accumulate this knowledge. Thus, firms face an inelastic supply of managerial services in the short run because no such labor market exists.

Penrose does not consider external conditions as serious barriers to growth because a firm can always escape stagnant markets by diversifying into other product markets or geographical locations (1959: 43). According to Penrose, the notion that a firm's growth is inhibited by external conditions typically should be attributed to its lack of entrepreneurial capabilities. She acknowledges that it is difficult for a firm to diversify into entirely new areas of specialization, and she favors finding new markets in which the firm can build on its existing competencies (1959: 130). This early Penrosean insight is consistent with research that empirically corroborates and explains why firms are more successful when conducting related rather than unrelated product diversification (Teece, 1982). Similarly, for international expansion, it is difficult for a firm to penetrate a distant host country because its underutilized resources can be costly to transfer across borders (Rugman \& Verbeke, 2003). Dissimilarity between the firm's existing activities and markets and the new activities (and the new market conditions) increases the amount 
of managerial services required for the successful execution of international entrepreneurial activities (Verbeke \& Yuan, 2007); this managerial bottleneck reduces the speed of international expansion (Hutzschenreuter et al., 2011).

Growth trajectory. The managerial constraint on the growth of a firm, or the so-called "Penrose effect" (Shen, 1970; Slater, 1980), predicts that a fast-growing firm will encounter managerial problems that impede its growth in the subsequent time period. The Penrose effect has been corroborated empirically in both domestic and international contexts (e.g., Hashai, 2011; Mohr, Batsakis, \& Stone, 2018). Penrose (1959) describes an endogenous model of the growth of a firm in which managerial learning within the firm can facilitate and constrain the growth of the firm (Pitelis, 2000). This endogenous model implies that firms can manage their own growth through careful organizational design. The upshot of Penrose's theory is the message that management matters.

Even though Penrose (1959) did not explain the process and the growth of MNEs explicitly, ${ }^{4}$ a few prominent IB scholars have extended Penrosean theory to explain and predict the growth of MNEs. For example, internationalization process theory (Johanson \& Vahlne, 1977, 1990), which is influenced by Penrose's growth theory, presents the process of international expansion as an iterative process of commitment to host markets and learning that leads to the accumulation of knowledge about the markets. Dynamic capabilities (Teece, Pisano \& Shuen, 1997), for which Augier and Teece (2007) credit Penrose (1959) as being an inspiration, consider the firm's ability to shape and configure resource bases to respond to changing technologies and markets as the foundations for long-term profitable growth of firms. Augier and Teece (2007) suggest that, while Penrose might not have fully developed the capability concept for MNEs, the development of the dynamic capability approach can be applied usefully to MNEs. Teece (2014) emphasizes dynamic capabilities and the importance of entrepreneurial management and transformational leadership in enabling MNEs to sustain performance in changing global environments. Furthermore, Buckley and Casson (2007) offer a mathematical model of Penrose's growth theory that considers international expansion and product diversification as alternative growth directions, and it incorporates technological innovation as a key driver of growth in which decreasing returns to R\&D act as a growth constraint. Building on Penrose, Dunning (2003) identifies a number of conditional ownership advantages that

\footnotetext{
4 Penrose maintains that the establishment of foreign subsidiaries is "still part of the process of growth of the parent company" (1956: 225), except that foreign subsidiaries might have a greater degree of independence from their corporate parent because they operate in different environments (1956: 226).
} 
accrued to large, multinational firms, which can be the basis for MNEs achieving profitable growth. Relatedly, Pitelis (2002) articulates Penrosean insights relevant to Dunning's (1980) ownership, location, and internalization (OLI) paradigm and explained how Penrose's work can contribute to theories on foreign direct investment (FDI) and enhance the understanding of the growth of MNEs. Pitelis and Verbeke (2007) propose three ways of extending Penrose's theory to explain the growth of MNEs, including technology-based firm-specific advantages, dynamic capabilities, and integrating location-bound and internationally transferable knowledge. Verbeke and Yuan (2007) apply Penrose's ideas to propose three conditions under which firms are more likely to encounter managerial constraints, such as a broad scope and high complexity of international activities, dissimilarity between existing and new activities, and dissimilarity between existing and new market conditions. In addition to these conceptual contributions, several empirical studies have drawn from Penrose (1959) to examine the growth of MNEs, which we discuss in the review section of this paper.

\section{REVIEW METHODOLOGY}

Penrose's (1959) theory provides useful guidance for constructing our review of research on the determinants of the growth of MNEs. In particular, Penrose considers diversification as a general growth policy in which growth is not restricted to particular geographical or product markets. Therefore, new entry and sequential expansion in a particular foreign market (either in the form of growth of the subsidiary or establishment of additional subsidiaries) contribute to the growth of MNEs. In addition, Penrose's assumption that firms seek profitable growth implies that divestments and exit activities of MNEs ultimately are part of the growth process. Thus, we consider such research relevant in our literature review. ${ }^{5}$ Given space limitations and the considerable amount of literature on foreign market entry, we focused on the conceptual and empirical articles published between 1995 and 2019 in leading management journals, e.g., Academy of Management Journal, Academy of Management Review, Administrative Science Quarterly, Journal of Management, Journal of Management Studies, Organization Science, and the

\footnotetext{
5 We focused on the growth of MNEs and avoid overlapping with prior literature reviews on growth of new ventures (Gilbert, McDougall, \& Audretsch, 2006), small- and median-sized firms (Coviello \& McAuley, 1999), international entrepreneurship (Terjesen, Hessels, \& Li, 2016), performance of international joint ventures (Ren, Gray, \& Kim, 2009), and international diversification (Hitt, Tihanyi, Miller, \& Connelly, 2006b). We did not review studies on foreign market, but readers can refer to Brouthers and Hennart (2007) for this information. However, we included eight articles based on small-sized and medium-sized firms because these articles discuss the longterm growth of venture/small firms as MNEs, and the international growth of the sample firms in the articles include FDI. Hence, we consider these articles relevant to our review.
} 
Strategic Management Journal. Also, we focused on leading IB-specific journals from 1995 to 2019, including the Journal of International Business Studies, Global Strategy Journal, Journal of World Business, and Management International Review. Thus, we curated scholarly publications dating back for a quarter of a century. We searched titles and abstracts of these targeted journals for the keywords of grow/growth, market entry, expand/expansion, internationalize/internationalization, (internationalise/internationalisation), speed, trajectory, evolve/evolution, exit/ survival, divest/divestment, downsize/downsizing, and Penrose/Penrosean. Our initial search identified 3,020 articles, and we reviewed the titles and abstracts of the articles for relevance. Many articles were eliminated due to their lack of international content. Further, for the Journal of International Business Studies, the flagship journal that focuses on international business research, we reviewed the title and abstract of each article for all issues over the study period, thereby identifying six additional articles. These search processes produced 190 articles that are of interest. Next, we searched titles and abstracts of the targeted journals for the keywords of international performance and international diversification, because studies that focus on these topics might measure performance based on growth. This search yielded 1,244 articles, 68 of which appeared in our earlier keyword search. We reviewed the titles, abstracts, and the methodology sections of all of the remaining articles; we identified nine additional articles with dependent variables that consist of at least one measure of growth. Combining this with the 190 articles, our final sample consists of 199 articles.

Note that our review focus on research related to the growth of MNEs. Although Penrose's work on MNEs (e.g., 1956, 1968, 1973) focused mainly on the impact of MNEs on the economic welfare of host countries (Dunning, 2003; Pitelis, 2004; Rugman \& Verbeke, 2002), our review does not cover this topic because it has been well covered elsewhere. On this topic, interested readers could refer to recent reviews on the impact of MNEs on host economies, such as spillovers (Abebe \& Begum, 2016; Meyer \& Sinani, 2009) and host-country competition (Forte, 2015).

\section{A REVIEW OF INTERNATIONAL BUSINESS RESEARCH ON MNE GROWTH}

\section{Overview of the Focus in Research on MNE Growth}

Our literature review consists of 199 articles in which the research inquiries are focused on the determinants of the growth of MNEs, which could be the result of entering new foreign markets as well as expansion/divestment in the 
host country. To understand how the focus of the research evolved, we classified all articles into five key categories: (1) growth via initial entry into foreign markets; (2) sequential expansion in the foreign markets; (3) survival, exit, or divestment; (4) overall growth of the MNE in the form of international scope and intensity (including international diversification and multinationality); and (5) the growth trajectories of the MNEs. These categories are not mutually exclusive, and we assigned some articles to more than one category. For example, Nachum and Song (2011) examine whether MNE characteristics have different impacts on their foreign expansion and contraction. Therefore, this journal article was classified under both category (1) and category (3). Figure 1a shows the number of articles in each category for every five-year period from 1995 to 2019. Overall, the number of studies on the growth of MNEs has been increasing in recent years. Studies on foreign market entry constitute the largest research category in the research relative to the growth of MNEs (approximately $32 \%$ of our review articles), and this is followed by studies on the international scope and intensity (28\%). These two categories received substantial research attention because they represent fundamental inquiries associated with the existence of MNEs. Approximately $24 \%$ of the studies focus on survival, exit, and divestment as well as subsequent expansion (21\%). Research on the trajectory of the growth of MNEs received less attention (9\%), probably because this topic requires longitudinal data, which are difficult to attain. In summary, Figure 1a shows that four areas of research, i.e., foreign market entry, sequential expansion, multinationality, and growth trajectory, increased over the study period (19952019), indicating that the growth of MNEs is a trending issue in the IB research literature.

Given that we use Penrose's growth theory to organize our review, we consider how many and what types of studies on MNE growth cited Penrose. Figure 1b classifies the articles that cite Penrose by our five categories, and it shows that Penrose's theory is relevant to every topic related to MNE growth, but it is particularly influential concerning the topic of growth trajectory, in which $39 \%$ of the articles cite Penrose's work. Her direct influence on the other categories is reflected by the citation percentages of $32 \%$ for expansion in foreign markets, $23 \%$ for foreign market entry, $15 \%$ for survival, exit, and divestment, and $16 \%$ for international scope and intensity.

\section{Overview of the Determinants of MNE Growth}

Given that Penrose's theory pays central attention to the facilitators, constraints, and process of the growth of firms, we present our review in three sections that summarize and synthesize research findings of the facilitators, 
constraints, and trajectory of the growth of MNEs. Facilitators are theoretically grounded factors that enhance the growth of MNEs, where growth can take the form of new entries into foreign markets, subsequent expansion in a particular market, or an increased level of internationalization of the MNE. Constraints are theoretically grounded factors that impede the growth of MNEs, including those that deter the entry to and expansion in host countries and those that lead to exits from or divestments in host countries. In addition, our review reveals that certain factors moderate the effects of facilitators and constraints, and we report these findings in the sections on facilitators and constraints. Given that we review the growth of MNEs through a Penrosean lens, we conclude each subsection with a discussion of Penrose's insights into the research findings related to MNEs' growth. Figure 2 shows a conceptual diagram for determinants (including facilitators, constraints and moderators) of the growth of MNEs.

\section{Facilitators of MNE Growth}

Several mainstream IB theories have offered key theoretical insights concerning the facilitators of the growth of MNEs. The internalization theory of FDI explains the existence of multinational firms, and it maintains that firm-specific advantages, the transfer of which involves high transaction costs, facilitate the growth of firms in foreign markets (Buckley \& Casson, 1976; Hennart, 1982; Rugman 1981). Internationalization process theory, which has its roots in Penrose's theory of the firm, suggests that experiential learning of knowledge about the host country increases a firm's commitments in pursuing growth in the host country (Johanson \& Vahlne, 1977). Recent research on emerging-economy MNEs (EMNEs) suggests that resource deficiency at home motivates these firms to seek strategic assets in advanced economies (Luo \& Tung, 2007; Makino, Lau, \& Yeh, 2002).

In our review, we find that factors that facilitate the growth of MNEs can be categorized broadly into the following categories, i.e., underutilized firm-specific resources, managerial resources, experiential learning, and external drivers. Concerning the facilitators of growth, not all research on the growth of MNEs draws explicitly on Penrose's theory, but this research is consistent with Penrose's theory in that it focuses on underutilized, firm-specific resources, managerial resources, and experiential learning as key drivers of the growth of the firm. In terms of the fourth facilitator, i.e., external drivers, the two lines of research differ in how they view the role of external conditions. Penrose suggests that managers perceive and interpret market conditions subjectively; hence, markets are 'created.' She focuses on purposeful internal drivers of growth (i.e., endogenous growth), and 
attributes the lack of growth opportunities to weak entrepreneurial capabilities and/or a lack of impregnable resource bases in the firm. In contrast, many studies of the growth of MNEs have attributed a firm's international growth primarily to external conditions. From a Penrosean perspective, the fact that favorable conditions in the host market encourage a firm to expand indicates that its managers are aware of market conditions and are capable of responding to them. Thus, knowledge of these market conditions and the vision of how to penetrate such markets are understood as part of the firm's entrepreneurial capabilities. Below we report findings from our review concerning the effects of the four key facilitators on the growth of MNEs. Table 1 summarizes these findings.

Firm-specific resources. Internationalization theory (Buckley \& Casson, 1976; Hennart, 1982; Rugman, 1981) views firm-specific resources, especially those that are intangible, as the main reason firms pursue international growth because the economic value of such resources does not depreciate through use. Since these resources constantly are underutilized (Caves, 1971), managers are motivated to pursue further exploitation in foreign markets. Given that intangible resources are fraught with contractual hazards and incur substantial costs when exchanged in the market, it often is relatively cost-efficient for firms to exploit them through FDI rather than through market mechanisms. Thus, the exploitation of firm-specific intangible resources largely explains the emergence of MNEs and their growth in foreign markets. In addition, firm-specific intangible resources often are proprietary, resist imitation (Chi, 1994), and provide monopolistic advantages that enable MNEs to overcome the liability of foreignness (Hymer, 1960). These resources enable firms to outcompete rival firms in foreign markets, and achieve and sustain profitable growth. Classic examples of firm-specific intangible resources shown to facilitate the growth of MNEs include technological knowledge and marketing knowledge (Chang, 1995; Delios \& Beamish, 1999; Hennart \& Park, 1994; Tan \& Vertinsky, 1996; Tseng, Tansuhaj, Hallagan, \& McCullough, 2007). A meta-analysis (Kirca et al., 2011) reports that technological knowledge has a more significant positive effect on the internationalization of firms than does marketing knowledge. R\&D activities help generate a continuous stream of new products and enable firms to maintain competitiveness and profitability when pursuing growth in global markets (Buckley \& Casson, 2007). Firmspecific resources include production-related proprietary resources as well as "an organizational capability to efficiently coordinate and control the MNEs' asset base" (Rugman \& Verbeke, 2001: 238). An example, 
documented by Pedersen and Shaver (2011), is firm-specific management infrastructure for international expansion, which has natural economies of scale that promote further international growth.

Exploiting firm-specific intangible resources requires a firm to transfer or replicate resources in foreign operations (Teece, 1977). The costs of transferring intangible resources increase with the tacitness of resources (Kogut \& Zander, 1992; Teece, 1981). Martin and Salomon (2003) show that the tacitness of a firm's technology has an inverted-U shaped relationship with the likelihood of a firm choosing FDI, which suggests that even though technology assets in general encourage international growth, the cost of transferring highly tacit technology can hamper a firm's growth in foreign markets. In addition, the (limited) fungibility of resources across national borders influences international growth. Some of the intangible resources of the firm might be valuable for all regions (i.e., non-location-bound), while others may be relevant only for certain regions or countries (i.e., location-bound) (Rugman \& Verbeke, 1992, 2004). Location-bound resources inhibit the firm's growth in other locations (Mauri, Song, \& de Figueiredo, 2017).

Firm-specific resources may lose value not only in different geographical locations but also in changing environments. Therefore, MNEs must develop dynamic capabilities to adapt to changing environments (Luo, 2000; Pitelis \& Teece, 2010; Teece, 2007, 2014; Teece et al., 1997). Vahlne and Ivarsson (2014) propose that the dynamic capabilities of MNEs might consist of their entrepreneurial ability and transformational leadership to identify and implement growth opportunities (Teece, 2007, 2014), networking capability (Johanson \& Vahlne, 2009), technology development capability (Buckley \& Casson, 2007; Dunning \& Lundan, 2008), and the capacity to develop knowledge on managing foreign operations. Research on MNE growth also emphasizes operational flexibility (Chi, Li, Trigeorgis, \& Tsekrekos, 2019), which is associated with the ability of firms to relocate sourcing, production, or distribution activities from one geographical location to another in short time-periods when facing environmental changes. Further, international expansion can be viewed as a mechanism through which firms can renew their firm-specific resources through (1) their interaction with foreign environments (Cantwell, 1989, 2009; Dunning, 1979; Pitelis \& Teece, 2010; Rugman \& Verbeke, 1992, 2001), (2) acquiring new strategic assets in advanced economies (Luo \& Tung, 2007), and (3) leveraging subsidiaries' initiatives (Birkinshaw, 1997; Birkinshaw \& Hood, 1998). Finally, foreign subsidiaries can play an important role in shaping the overall 
capabilities of MNEs (Birkinshaw, 1997; Cantwell \& Mudambi, 2005), but, in our sample, only two empirical studies (Kafouros \& Aliyev, 2016; Lee, Chung, \& Beamish, 2019) focus on resources at the subsidiary level.

In summary, research concerning the growth of MNEs has provided ample evidence for the materiality of the firm-specific (especially intangible) resources for expansion of firms into foreign markets. The value to be derived from firm-specific intangible resources depends on the degree of tacitness, fungibility, and adaptability of those resources. It is noted that the research streams on the growth of MNEs and on Penrose (1959) consider underutilized, firm-specific resources as the basis on which firms can expand into new geographical or product markets. For research on the growth of MNEs, resources are underutilized primarily because of their intangible nature, whereas, in Penrose's theory, resources are underutilized due to the indivisibility of assets, fungibility, and continuous managerial learning about resources. In terms of enablers of long-term, profitable growth, the research on MNE growth emphasizes the dynamic capabilities and operating flexibility that help firms adapt to changing technological, economic, and institutional environments. Also, this research considers inter-national expansion as an opportunity to adapt and strengthen firm-specific resources. Similarly, Penrose emphasizes the capability to build versatile and impregnable (technological) "bases" (1959: 137) that enables the pursuit of growth via (related) product diversification (Buckley \& Casson, 2007), which creates a virtuous cycle of 'resource learning' and innovation.

Managerial resources. Research on the growth of MNEs has shown that managers have a key role in orchestrating the growth of their firms. In addition to Penrose's growth theory, this research draws on upper echelon theory, agency-theoretic corporate governance, and internationalization process theory, and it focuses on managerial attributes and governance conditions that shape managerial incentives and capabilities to formulate or implement international growth strategies.

An extensively examined managerial attribute is international work experience, which, in theory, enhances managers' awareness of promising international business opportunities and effective implementation of international expansion. Empirical research has corroborated that MNEs whose managers have greater international experience achieve a higher level of internationalization (Athanassiou \& Nigh, 2002; Carpenter \& Fredrickson, 2001; Chen, Chang, \& Hsu, 2017; Nielsen, 2010; Sambharya, 1996). However, case-study research indicates 
that an imprinting effect of prior international experience may reduce managerial motivation to learn, which can have a negative effect on the long-term growth of the firm (Bingham \& Davis, 2012). Other managerial attributes, such as industry experience and elite education, also are shown to facilitate international growth (Chen et al., 2017; Tihanyi, Ellstrand, Daily, \& Dalton, 2000).

In addition to managerial experience, managers' network connections also are an important driver for identifying opportunities for profitable international growth (Johanson \& Vahlne, 2006, 2009). Managerial connections can be particularly useful when MNEs seek to penetrate a foreign market. For example, managers' cooperative relationships with local and central governments in host countries provide firms with preferential access to scarce resources, such as permits and licenses, resulting in higher subsidiary growth (Luo, 2001). Co-ethnic networks in one location of the host country increase the likelihood of subsequent investment in other co-ethnic locations, and they accelerate the overall pace of growth in the host country (Stallkamp, Pinkham, Schotter, \& Buchel, 2018). However, managerial connections also might constrain growth opportunities in terms of the geographical locations that managers favor due to close ties and/or prior experience (Musteen, Francis, \& Datta, 2010). Similarly, home country network connections tend to promote domestic growth at the expense of international expansion (Bai, Chen, \& He, 2019; Fernández-Méndez, García-Canal, \& Guillén, 2018; Iurkov \& Benito, 2018). Overall, international diversity is the type of managerial connection that leads to long-term international growth (Hagen \& Zucchella, 2014; Stoian, Dimitratos, \& Plakoyiannaki, 2018). Given that managers work collectively as a team, the composition of the management team matters. Top management team (TMT) diversity, which implies heterogeneity in experience, skills, and viewpoints, can facilitate the exploration of new growth opportunities in foreign markets. TMT diversity is shown to increase the novelty of FDI locations (Barkema \& Shvyrkov, 2007), but the link between the diversity of the TMT and the growth of MNEs remains unclear. Some empirical studies find a positive association between the growth of MNEs and the diversity of the TMT's international experience (Sambharya, 1996), education (Carpenter \& Fredrickson, 2001), and firm/team tenure (Carpenter \& Fredrickson, 2001; Tihanyi et al., 2000), but other research studies fail to find such associations (Barkema \& Shvyrkov, 2007). It may be that too much diversity on a team can lead to difficulties in reaching consensus when making decisions, thereby hampering inter- 
national growth. Yet, few attempts are made to test the curvilinear relationship between the growth of MNEs and the diversity of the TMT, and those attempts lack empirical support (Carpenter \& Fredrickson, 2001).

Several research studies have utilized the upper echelon theory, the corporate governance literature, and information processing theory to examine the managerial characteristics or corporate governance mechanisms that influence managers' incentives to pursue growth in risky international markets. Narcissistic CEOs tend to be aggressive and have more confidence in pursuing international growth (Agnihotri \& Bhattacharya, 2019). A young and elitely educated TMT or a large board expands a firm's information processing capacity, and increases managers' willingness to assume risk and undertake international expansion (Hitt et al., 2006b; Singh \& Delios, 2017; Tihanyi et al., 2000). Outside directors and institutional investors (such as mutual funds or pension funds) can assist managers in identifying international opportunities and thus promote international expansion (Majocchi \& Strange, 2012; Tihanyi, Johnson, Hoskisson, \& Hitt, 2003). CEO duality, which agency theory predicts to be an undesirable board leadership structure, is found to be linked positively with international expansion because CEO duality can serve as unified leadership and expedite decision-making (Singh \& Delios, 2017). Similarly, CEOs who are owners of the firms have the power to take on strategic decisions, including undertaking international expansion (Chittor, Aulakh, \& Ray, 2019). In addition, contingent pay and firm-level resource slack increase managerial incentives to seek new international growth opportunities (Dagnino, Giachetti, La Rocca, \& Picone, 2019; Lin, 2014, Tihanyi, Hoskisson, Johnson, \& Wan, 2009). Similarly, in state-owned enterprises (SOEs), soft-budget constraints and long-term investment horizons can encourage managers to take on risky projects, such as international investments (Rudy, Miller, \& Wang, 2016), especially when the governance framework in the country curtails SOE managers' pursuits for private benefits (Estrin, Meyer, Nielsen \& Nielsen, 2016) or even sets goals for SOEs to pursue international growth (Mariotti \& Marzano, 2019). On the negative side, top managers' inertia and unwillingness to take risk inhibit decisions to expand into foreign markets (Dow, Liesch, \& Welch, 2018).

Several studies have drawn on the research literature on expatriate managers (Boyacigiller, 1990; Edström \& Galbraith, 1977) and Penrose (1959) to examine the utilization of expatriates on subsidiary growth. Given that expatriate managers serve as knowledge transfer and coordinating mechanisms between the head- 
quarters (HQ) of the MNEs and their subsidiaries, multinational firms that send more expatriates (most of whom are managers) to their subsidiaries in initial periods and those who replace expatriates with foreign personnel at a slower rate achieve higher growth rates over time. Essentially, these firms are better able to transfer knowledge (Kawai \& Chung, 2019) and to train and integrate the new members in their subsidiaries (Riaz, Rowe, \& Beamish, 2014; Tan \& Mahoney, 2007).

Note that the empirical results reviewed in this section are based on the managers at the HQs of the MNEs. However, subsidiary initiatives are an important part of corporate entrepreneurship that can drive the growth of MNEs in foreign markets (Birkinshaw, 1997). Thus, additional empirical research is needed to examine how subsidiary managers influence the overall growth of MNEs.

Overall, the extant growth research of MNEs on managerial resources has focused primarily focused on managerial attributes and governance conditions that might affect managerial incentives and capabilities to formulate and implement international growth strategies as opposed to firm-specific managerial capabilities in maintaining coordination within MNEs, which receives central attention in Penrose's growth theory. Given that an MNE consists of a group of geographically dispersed, goal-disparate organizations (Ghoshal \& Bartlett, 1990), maintaining internal coordination and control within the MNE involves challenging managerial problems, such as potential conflicts and the incongruence of goals between the HQ and the foreign operations (Nohria \& Ghoshal, 1994; Verbeke \& Yuan, 2005). Thus, whether and how firm-specific managerial experience at the HQs of MNEs enhances the management of foreign operations and facilitates growth is likely a worthy research direction.

Recent developments in the dynamic capabilities approach (Teece, 2014) and dynamic managerial capabilities (Adner \& Helfat, 2003; Helfat \& Martin, 2015) have emphasized the entrepreneurial qualities of the TMT as a key factor in sustaining long-term competitive advantages in global markets. Our review suggests that the diversity of the experiences of the TMT might contribute to such qualities. More research is needed to understand what constitutes the entrepreneurial capabilities of MNEs that facilitate continued entries into new foreign markets.

Experiential Learning. The growth of MNEs requires general knowledge of international management and market-specific knowledge, much of which is less structured and gained mainly through experience (Johanson 
\& Vahlne, 1977). Internationalization process theory (Johanson \& Vahlne, 1977, 1990) suggests that experiential learning enables managers to recognize growth opportunities better, and reduces the perceived risk associated with growth, thereby increasing commitments in foreign markets. Experiential learning takes the form of direct learning and indirect learning (i.e., learning from the experience of other people) (Bingham \& Davis, 2012). Extant research has drawn on internationalization process theory, organizational learning literature, and the behavioral theory of the firm to examine the impact of both types of learning on the growth of MNEs. In terms of direct learning, a firm's experience in international activities increases the speed of its overall international expansion (Hutzschenreuter, Kleindienst, Guenther, \& Hammes, 2016), but its impact is decreased when the firm already has host-country experience (Henisz \& Delios, 2001). The transferability of general international experience to a particular subsidiary is also reduced when the cultural context of the subsidiary is more distant from the cultures in which the firm has accumulated experience (Barkema, Bell, \& Pennings, 1996). In addition, the geographical makeup of a firm's international activities makes a difference. Specifically, the depth of international activities (as reflected by a firm's experience in a certain host country) has an inverted U-shaped relationship with the speed of international expansion (Casillas \& Moreno-Menendez, 2014). This outcome occurs because, even though it is easier for firms to expand in markets where they already have experience, opportunities for further learning are limited in such markets. The impact of the diversity of international activities (i.e., host-country dispersion) on growth is found to be mixed (i.e., direct positive and indirect negative effects). A high level of international diversity enables firms to accumulate extensive knowledge of the markets, which supports international growth in the long term (Casillas \& Moreno-Menendez, 2014; Nachum \& Song, 2011; Zhou \& Guillén, 2015). However, high international diversity also creates coordination costs (Schu, Morschett, \& Swoboda, 2016) and information overload that impedes technological learning, which has an indirect negative effect on international growth (Zahra, Ireland, \& Hitt, 2000).

Market-specific experience matters when it comes to international growth. Research shows that experience in the host country increases a firm's sales growth in that market (Luo, 1999) and reduces the exit rate in both the host country (Delios \& Beamish, 2001; Gaur \& Lu, 2007; Li, 1995) and other countries with similar institutional environments (Perkins, 2014). The positive effect of host-country experience on growth is even greater in 
countries in which the quality of institutions is poor ( $\mathrm{Lu}, \mathrm{Liu}$, Wright, \& Filatochev, 2014). However, once exiting from a host country, the experience the firm accumulated during its stay in that country has no impact on the firm's further decisions in that country (Surdu, Mellahi, \& Glaister, 2019). Moreover, experiential learning at home is found to contribute to international growth. A firm's experience with a certain technology in its home country can reduce the cost of transferring the technology to foreign operations, thereby enabling greater international growth (Martin \& Salomon, 2003). Firms with substantial experience in making domestic and foreign acquisitions have built and refined acquisition routines that facilitate the firm's international growth through acquisitions (Nadolska \& Barkema, 2007). Similarly, a firm's domestic dispersion enables the firm to develop capabilities to coordinate remote business units, which can subsequently be used to support international growth (Santangelo \& Stucchi, 2018). Finally, a firm's prior experience of inward internationalization at home, such as export and original equipment manufacturing activities, nurtures its international management capabilities and enables faster international growth (Luo \& $\mathrm{Bu}, 2018$ ).

In addition to direct experiential learning, indirect learning also can facilitate international growth. Observing or interacting with other firms that have experience in the host country enables a firm to gain knowledge and information that help to reduce uncertainty about the host country. Research shows that firms can achieve greater international growth and a lower exit rate if they have foreign alliance partners (Cesinger, Hughes, Mensching, Bouncken, Fredrich, \& Kraus, 2016; Hong \& Lee, 2015), interlocking partners (Xia, Ma, Tong, \& Li, 2018), and inward international activities (Li, Li, \& Shapiro, 2012; Li, Yi, \& Cui, 2017), as well as following a shared industry recipe (Monaghan \& Tippmann, 2018). Firms also can obtain information spillover from other firms (Henisz \& Delios, 2001; Shaver, Mitchell, \& Yeung, 1997), such as other firms from the same country of origin (Hernandez, 2014; Tan \& Meyer, 2011) unless agglomeration with other firms creates a knowledge leakage hazard that threatens survival (Mariotti, Mosconi, \& Piscitello, 2019; Shaver \& Flyer, 2000). Although these different sources of external experiential knowledge all make positive contributions to international growth, their relative impacts might be different. For example, prior acquisition experience of a firm's interlocking partners has a greater impact on the growth of MNEs than that of joint venture partners (Xia et al., 2018). In addition, intra-MNE networks or business groups can be a reservoir for learning (Eriksson, Johanson, Majkgård, \& Sharma, 1997). Subsidiaries 
achieve greater growth by learning from strategic decisions of the intra-MNE network (Banerji \& Sambharya, 1996; Gaur, Kumar, \& Singh, 2014; Gaur \& Lu, 2007; Guillén, 2003; Kim, Lu, \& Rhee, 2012). The learning opportunities within the intra-MNE networks are greater in the presence of diversity. For example, a subsidiary's learning from its sister subsidiaries yields more non-redundant knowledge if they are from different entry cohorts (Kim et al., 2012).

Research has indicated that direct learning and indirect learning are alternative sources of knowledge about foreign markets. Firms with direct experience are less influenced by other firms' experience in making their decisions concerning international expansion (Gupta \& Misangyi, 2018; Henisz \& Delios, 2001). Similarly, in the presence of indirect learning, direct experience is less influential on the firm's international growth (Cui, Li, Meyer, \& Li, 2015; Hutzschenreuter et al., 2016). Even so, empirical evidence shows that direct learning can be supportive of indirect learning by enhancing a firm's ability to absorb knowledge from other firms. For example, Kim et al. (2012) report that the prior experience of sister subsidiaries can reduce the exit rate of a subsidiary more effectively when the parent has experience in the host country or general international experience. In sum, direct and indirect sources of learning have been found to be substitutive, but these sources of learning also can be complementary and reinforcing. These substitution and synergistic effects constitute a fertile ground for future empirical studies.

Overall, MNE growth research and Penrose's theory are similar in that they indicate that growth can be generated internally through experiential learning. Penrose's growth theory suggests that the process of learningby-doing that occurs within a firm generates new knowledge for further utilization. The research on the growth of MNEs corroborates that experiential learning through international expansion enables a firm to accumulate knowledge concerning the host country (Johanson \& Vahlne, 1977, 1990), combine locational advantages with its own resources (Dunning, 1993), and locally adapt their firm-specific advantages (Rugman \& Verbeke, 2001). Yet, there is a notable difference between the two approaches when it comes to the main objects of learning. Penrose focuses on (direct) firm-specific learning that facilitates the integration of new knowledge and enhances the coordination of the complex (i.e., internationally diversified) organization. In contrast, much of the MNE growth research focuses singularly on the need to address differences in foreign markets, and thus pays attention to any learning (direct or indirect) that provides knowledge about foreign markets (Steen \& Liesch, 2007). Other streams of research in the IB literature have substantial discussions on maintaining integration within MNEs (e.g., 
O'Donnell, 2000; Prahalad \& Doz, 1987), but most do not connect the notion of administrative coordination to the growth of MNEs.

External drivers. Extant research has drawn on emerging economy research and institutional economics to examine a wide range of host and home country-level conditions that drive a firm's profitable growth in international markets. Empirical studies have shown that improved conditions in the host country, such as high demand growth, pro-market reform, market-supporting institutions and infrastructure, and regulatory support from the country's governments, enhance the survival and growth of subsidiaries in the host country (Belderbos \& Zou, 2007; Dau, 2012; Dunning \& Kundu, 1995; Guler \& Guillén, 2010a; Liao \& Yu, 2012; Paul \& Wooster, 2008; Surdu et al., 2018; Surdu, Mellahi, Glaister, \& Nardella, 2019; Tschoeg1, 2002; Van Den Bulcke, Zhang \& Li, 1999). Support from home governments also can facilitate the international expansion of firms (Finchelstein, 2017; Gaur, Ma, \& Ding, 2018). In addition, a firm's international growth can be an outcome of its attempt to escape unfavorable conditions at home, such as having a small home market (Lindqvist, 1991), poor protection of investors and a limited market for external capital (Li \& Yue, 2008), corruption (Bertrand, Betschinger, \& Laamanen, 2019), and institutional uncertainty and turbulence (Fathallah, Branzei, \& Schaan, 2018; Shi, Sun, Yan, \& Zhu, 2017), especially for young and non-group affiliated firms that have substantial disadvantages at home (Kumar, Singh, Purkayastha, Popli, \& Gaur, 2020). In particular, home-based scarcity of advanced technology motivates the expansion of EMNEs into advanced countries so they can acquire advanced technological knowledge (Gaur et al., 2018; Luo \& Tung, 2007). However, inward FDI activities in the EMNEs' home countries might provide similar benefits and reduce such a propensity (Li et al., 2012; Li et al., 2017). Expanding into more advanced countries gives EMNEs access to strategic resources (Luo \& Tung, 2007; Madhok \& Keyhani, 2012; Young, Huang, \& McDermott, 1996) and facilitates organizational change in the EMNEs (Kalasin, Dussauge, \& Rivera-Santos, 2014). Then, with stronger competitive positioning, these firms can pursue sequential expansion in global markets.

A wide spectrum of competitive and cooperative conditions in the industry can shape the growth of MNEs. Early FDI research shows that a firm's international expansion can be an oligopolistic reaction to domestic competitors (i.e., follow-the-leader) or foreign competitors (exchange-of-hostage) (Flowers, 1976; Hennart \& Park, 1994; Knickerbocker, 1973; Yu \& Ito, 1988). Studies that are more recent have corroborated that firms are more 
likely to expand in a host market as a response to foreign competitors (Hutzschenreuter \& Gröne, 2009; Ito \& Rose, 2002). Firms also follow their domestic competitors' FDI moves (Guillén, 2002; Li, Xia, Shapiro, \& Lin, 2018), but they only do so when they have a large or comparable market share compared to their competitors in domestic markets (Gimeno, Hoskisson, Beal, \& Wan, 2005). In addition, firms are less likely to follow either foreign or domestic competitors to enter a host market when competition in the market is intense (Chan, Makino, \& Isobe, 2006; Martin, Swaminathan, \& Mitchell, 1998).

Empirical studies have reported that a firm's expansion in foreign markets can be motivated by its domestic client's entry into the host market (Martin et al., 1998). Firms that occupy central positions in home networks are in a better position to attract exchange partners, which facilitates their expansion into foreign markets (Guler \& Guillén, 2010b). When MNEs are early entrants into a host market, they tend to capture early-mover advantages over competitors and achieve greater sales growth (Luo, 1998). Industries that are rapidly globalizing also push firms to expand their foreign activities to achieve economies of scale and scope so they can remain competitive with their global rivals (Chang \& Rosenzweig, 1998).

Overall, research has shown that host and home country-level and industry-level conditions have significant effects on a firm's profitable growth in international markets. From a Penrosean perspective, the fact that these external conditions encourage a firm to expand indicates that its managers are aware of market conditions and are capable of responding to them. Thus, knowledge of these external conditions and the ambition to penetrate the foreign markets constitute part of the firm's entrepreneurial capabilities.

Relationships between Facilitators. Penrose's theory and the research on the growth of MNEs take slightly different approaches to theorizing the relationships among facilitators. In Penrose's theory, the three main facilitators, i.e., firm-specific resources, managerial resources, and experiential learning, are interrelated and have their roots in the conceptualization of the firm. Penrose (1959) considers a firm as an administrative unit and a collection of productive resources, the disposal of which is determined by managers' decisions. Managerial firm-specific learning results in an increase in managers' knowledge and understanding about firms and their resources, which, in turn, increases the services available from those resources. Accordingly, Penrose predicts positive interactive effects between managerial firm-specific learning and resources. In comparison, in much of the MNE research, the growth 
effects of underutilized firm-specific resources, managers, and experiential learning are examined separately. The conceptualization of the firm typically is not used to derive the sources of facilitators of the growth of MNEs or to examine the interrelationships among them. Even so, our review of the research indicated that facilitators interact to make impacts on the growth of the MNEs. For example, managerial experience and the managers' connections with clients have a synergic effect on a firm's level of internationalization because experience enables managers to exploit their connections more effectively (Hitt, Bierman, Uhlenbruck, \& Shimizu, 2006a). International experience makes unfavorable conditions at home a stronger motivator for international growth (Gaur et al., 2018; Shi et al., 2017). International experience also increases the tendency of a firm to follow its clients (Qian \& Delios, 2008), but it decreases the firm's likelihood of matching its peers' entry into foreign markets (Gupta \& Misangyi, 2018). In terms of experiential learning, managerial characteristics and external conditions can influence how firms/ managers learn. For example, narcissistic CEOs rely more on direct learning rather than indirect learning (Zhu \& Chen, 2015). The Internet might speed up experiential learning and facilitate international expansion (Petersen, Welch, \& Liesch, 2002), especially for firms with prior international experience (Rhee, 2005). In summary, we have preliminary empirical evidence of interactions among the key facilitators of growth. However, more studies are needed to provide a theoretically grounded, empirical examination on how all four facilitators interact to influence the growth of MNEs.

\section{Constraints on MNE Growth}

Several research streams have provided insights concerning what constrains the growth of MNEs. Monopolistic advantage theory (Hymer, 1976) and research on the liability of foreignness (Zaheer, 1995) contend that MNEs incur additional costs when doing business abroad. The integration-responsiveness framework, which elaborates on the contingent strategies of MNEs based on their organizational setting (Prahalad \& Doz, 1987), underscores the importance of adapting to host-country differences while maintaining internal coordination. Research on cross-cultural management (Hofstede, 1984) and emerging economies (Hoskisson, Eden, Lau, \& Wright, 2000) also recognizes the challenges for MNEs in dealing with cross-country differences in cultural and institutional environments. Our review of the research on the growth of MNEs indicated that many of the studies focused on cross-country differences and risk/uncertainty, which are related to external conditions for MNEs. There 
are also studies that examined internal constraints, such as financial and managerial constraints, with the latter drawing explicitly on Penrose's growth theory. Penrose does not consider external conditions as serious barriers to growth, and she attributes any inability of a firm to alleviate external constraints to its insufficient managerial capabilities. Thus, Penrose would predict that managerial attributes/actions moderate (e.g., alleviate the negative) impact of external constraints on growth. This logic is consistent with many of the studies that discuss the conditions and strategies (managerial choices) that are likely to moderate the impacts of the external constraints on the growth of the MNEs. Below, we report the findings of these studies, which are summarized in Table 2.

Cross-country differences. Cross-country differences in terms of cultures, institutional conditions, and economic development increase a firm's knowledge gaps in host countries, create difficulties in transferring firm-specific resources and in building legitimacy (Ghemawat, 2001; Xu \& Shenkar, 2002), thus creating extra costs of doing business (Cuervo-Cazurra, Maloney, \& Manrakhan, 2007) and the liability of foreignness (Mata \& Freitas, 2012; Qian, Li, \& Rugman, 2013; Zaheer \& Mosakowski, 1997). As a result, firms might withhold their resource commitment to such host countries (Johanson \& Vahlne, 1977, 1990). Empirical evidence suggests that, in general, cross-country differences inhibit market entry (Berry, Guillén, \& Zhou, 2010), reduce the speed of expansion (Hutzschenreuter et al., 2011; Schu et al., 2016), and result in an exit from the host country (Demirbag, Apaydin, \& Tatoglu, 2011; Kang, Lee, \& Ghauri, 2017). These studies also show that cross-country distances have differential effects on firms. For example, the negative impact of cultural distance on the longevity of subsidiaries has been found to be stronger for joint ventures and acquisitions than for wholly owned investments and greenfield investments because the former modes require MNEs to accommodate both host country and corporate cultures of the target subsidiaries (Barkema et al., 1996). The negative impacts of cultural distance on the growth of MNEs also are stronger for larger and older firms because these firms tend to be bureaucratic and rigid, and they have difficulties in adapting to culturally distant host countries (Li, Zhang, \& Shi, 2019). Cross-country differences typically take the form of the Euclidean or Mahalanobis distance between home and host countries. However, given that a firm's stock of foreign market knowledge expands when it grows into different foreign locations, the concept of cross-country distance can be dynamic and firm-specific. Zhou and Guillén (2015) show that a firm's foreign location portfolio, or "home base," can better predict its foreign market entry than its home country. 
Early FDI theories posit that the liability of foreignness might be alleviated if MNEs possess monopolistic advantages (Dunning, 1980; Hymer, 1976). Empirical evidence has corroborated that a firm's technological capabilities reduce the negative impact of cross-country distance on the exit of its subsidiary (Kang et al., 2017). Yet, Xu and Shenkar (2002) propose that MNEs with strong firm-specific, routine-based, competitive advantages might be more vulnerable to normative institutional distances, because such firms tend to impose their own institutional norms and rules on foreign subsidiaries, and, thus, they are likely to find it costly to do so in host countries that are normatively distant.

Given that cross-country differences create a firm's knowledge gap, host-country experience should help to reduce the gap and the negative impact of cross-country differences (Johanson \& Vahlne, 1977, 1990). Indeed, cross-country differences are more strongly linked to the exits of the subsidiaries of MNEs that do not have experience in the host countries (Berry et al., 2010). However, research shows that the moderating effects of hostcountry experiences might be complex. Zeng, Shenkar, Lee, and Song (2013a) report that, at low levels, host-culture experience increases the mortality of subsidiaries in the host country until the MNEs have made four or more investments in the host culture. Moreover, Zeng, Shenkar, Song, and Lee (2013b) report similar empirical results for the growth of firms with limited (general) international experience in culturally dissimilar countries. Thus, it is likely that low levels of experience increase the propensity of the firms to make erroneous inferences from their experience.

In general, cross-country differences are viewed as a source of complexity and additional costs, but these differences can provide MNEs with arbitrage opportunities (Ghemawat, 2007; Nachum \& Song, 2011), and empirical evidence corroborates this view. For example, Tsang and Yip (2007) find that the exit rates of subsidiaries are lower in both economically less-developed countries and more developed countries (as opposed to moderately developed countries), because such variance provides opportunities for MNEs to explore or exploit the economic differences. Arregle, Miller, Hitt, and Beamish (2016) show that a moderate level of institutional diversity within a region enables firms to arbitrage institutional differences across countries within the region, but institutional diversity at high levels can create managerial and organizational problems for MNEs. In addition, cross-country differences can provide learning opportunities for the MNE as a whole. Two metaanalyses find that, even though cultural distance influences an MNE's entry and exit in a host country, it does not 
diminish its overall performance and the extent of its internationalization as a whole (Beugelsdijk, Kostova, Kunst, Spadafora, \& van Essen, 2018; Tihanyi, Griffith, \& Russell, 2005). Such empirical findings suggest that operating in culturally different countries might provide potential learning benefits for the entire MNE. Indeed, Zeng et al. (2013a) report that prior experience in dissimilar cultures improved the ability of the firm to generalize and apply its learning to a distant culture, resulting in reduced mortality of its subsidiaries.

Risk and uncertainty in host countries. Risk and uncertainty make it difficult for firms to assess the economic value of their investments in the host countries and hence deter entry. Once investments are made, unexpected events can change the payoff prospect of investments and increase the likelihood of divestments. Economics literature and the real options literature distinguish between endogenous and exogenous uncertainty (Bowman \& Hurry, 1993; Dixit \& Pindyck, 1994; Folta, 1998). Endogenous uncertainty arises from insufficient knowledge about foreign markets, and it can be mitigated by the acquisition of knowledge about the markets through direct or indirect learning (Buckley, Chen, Clegg, \& Voss, 2020; Johanson \& Vahlne, 1977, 1990) or by a real options approach in investment strategies, which can be applied to equity joint ventures (Kogut, 1991). Exogenous uncertainty is unaffected by the firm's actions and is typically reduced over time.

Our review finds that host-country uncertainty leads to slower growth as manifested by modest, incremental investments (Delios \& Henisz, 2003a, 2003b; Rhee \& Cheng, 2002) and delayed entry (Gaba, Pan, \& Ungson, 2002). Research also has examined exogenous uncertainty in a variety of forms, including political hazards (Dai, Eden, \& Beamish, 2013; Fernández-Méndez, García-Canal, \& Guillén, 2019; Henisz \& Delios, 2001; Zhong, Lin, Gao, \& Yang, 2019), institutional weakness (Dhanaraj \& Beamish, 2009; Getachew \& Beamish, 2017; Sartor \& Beamish, 2020), the fluctuation of exchange rates and labor costs (Fisch \& Zschoche, 2012; Song, 2014, 2015), economic crises (Belderbos \& Zou, 2009; Chung, Lee, Beamish, \& Isobe, 2010; Chung, Lee, \& Lee, 2013), and discontinuous shocks, such as war, terrorist attacks, natural disasters, and technological shutdowns (Dai, Eden, \& Beamish, 2017; Oetzel \& Oh, 2014; Pek, Oh, \& Rivera, 2018). These forms of uncertainty are found to deter investments or to lead to an exit from the host country, but the overall effect of uncertainty is more prominent when the macroeconomic environmental change in the host country is highly correlated with other countries in which the MNE has operations (Belderbos \& Zou, 2009). In addition, some forms of 
exogenous uncertainty have greater impacts than other forms. For example, Oh and Oetzel (2011) find that MNEs react more to technology disasters and terrorist attacks (via divestments) than they do to natural disasters. This outcome likely occurs because the impacts of the former types of disasters are more amplified socially.

This line of research identifies a number of characteristics and strategies of firms that act as moderators to alleviate the negative impact of risk/uncertainty on the growth of MNEs. These characteristics and strategies of firms can be classified broadly into five categories. First, firms with superior resources, such as technological capabilities and organizational slack, are less sensitive to the uncertainties associated with the host countries (Pek et al., 2018; Rhee \& Cheng, 2002). Firms with a broad scope of products and services have a greater likelihood of providing the right product and service to a host country when facing (endogenous) uncertainty associated with being earlier movers in the country (Gaba et al., 2002). MNEs that have greater ownership in their subsidiaries can implement corporate systems that prevent their subsidiaries from being entangled in corruption in host countries (Sartor \& Beamish, 2020). Second, managerial networking facilitates information exchange and enables access to external resources and supports. For example, Dai et al. (2013) finds that locating in country-of-origin agglomeration enables MNEs to undertake joint actions, such as lobbying to reduce political hazards in host countries. Chen, Li, and Fan (2018) propose that home and host political connections enable firms to grow in host countries with different institutional environments by providing them with resource support and legitimacy. Albino-Pimentel, Dussauge, and Shaver (2018) find that firms with home political connections have more choices of locations in foreign markets because they are more able to deal with government authorities in politically challenging environments. Third, direct learning helps to develop the skill repertoire that firms can use to manage risks. For example, MNEs with experience in dealing with political hazards and certain types of discontinuous risks are found to be less sensitive to such risks (Dai et al., 2017; Delios \& Henisz, 2003b; Oetzel \& Oh, 2014). The experience of EMNEs in dealing with weak institutional environments at home cultivates their capability in overcoming (or even leveraging) institutional weaknesses in other emerging and least developed economies (Cuervo-Cazurra \& Genc, 2008; Luiz, Stringfellow, \& Jefthas, 2017). Experiences may have to be specific to be useful in addressing exogenous uncertainty because general inter-national operating experience does not reduce the negative impact of exogenous uncertainty in a 
particular host country (Buckley et al., 2000). That said, international experience does enable firms to better discern and react to uncertainty by delaying entry decisions (Dowell \& Killaly, 2009). Fourth, firms with operating flexibility can escape unfavorable host-country conditions by shifting their operations to other countries (Kogut \& Kulatilaka, 1994). The choice of the location of a foreign market can be made in a way to diversify a firm's portfolios of locational and institutional risks (Luiz et al., 2017). In general, firms with multinational plant networks are better able to cope with changes in labor costs due to their flexibility in relocating product operations (Belderbos \& Zou, 2007). In addition, when facing fluctuations in macroeconomic conditions in host countries, firms are less likely to divest their subsidiaries that engage in greater intra-firm transactions (Chung et al., 2013; Song, 2015; Song \& Lee, 2017). This is especially the case for subsidiaries that are located in weak institutional environments in which intra-firm exchanges can attenuate transaction costs (Gaur, Pattnaik, Singh, \& Lee, 2019). Fifth, varieties of non-market strategies are shown to enable MNEs to solicit cooperation from the stakeholders in the host countries, thereby reducing the negative impact of exogenous uncertainty (Heidenreich, Mohr, \& Puck, 2015). Pek et al. (2018) show that firms' philanthropic capabilities enhanced their sociological legitimacy and enabled them to secure resources from stakeholders, such as governments or customers, to deal with industry disasters in the host countries. Ma and Delios (2010) suggest that the establishment of host-country HQs can be a political strategy for MNEs to reduce intervention from host governments in emerging markets. We also remind that some of the firm's characteristics that moderate the link between its growth and external conditions (e.g., firm-level resources, direct learning, and managerial networking) have direct effects on the growth of the MNE as facilitators, as discussed earlier in the current review.

Other host and home country conditions. Host-country cultural dimensions, such as uncertainty avoidance and collectivism, can challenge the viability of the online business model and inhibit international growth (Rothaermel, Kotha, \& Steensma, 2006). Also, other home conditions can impede international growth. Narula (2015) suggests that the poor state of knowledge of the infrastructure in India inhibits the development of innovation by small Indian firms and hampers their growth in international markets. Soule, Swaminathan, and Tihanyi (2014) report that social disapproval in the home country (e.g., the anti-Burma protests) reduces the 
inclination of MNEs to invest in a controversial host country (or encouraged divestment from this market).

Financial constraints. Research has shown that financial constraints affect both international growth and divestment decisions. Specifically, MNEs that do not have sufficient financial resources (indicated by low profitability, inadequate free cash flow, or too much debt) struggle to support international growth initiatives (Dagnino et al., 2019; Powell, 2014). Yet, evidence also shows that firms can strategically utilize company overvaluation to reduce the cost of external financing and thus to relieve their financial constraints (Yuan, Qian, \& Pangarkar, 2016). Unsatisfactory financial performance might increase the propensity of a firm searching for new markets (Shapira, 2017), but performance that is far below aspiration has a strong influence on an MNE's decision to withhold foreign market entry (Lim, 2019) or divest a foreign operation unless the poorly performing operation (e.g., subsidiary) has innovation capabilities (Tan \& Sousa, 2019), or is in a business domain related to that of the parents (Chang, 1996; Tan \& Sousa, 2018). Divestment becomes less likely in that case, especially when the subsidiary resides in a high-growth host country (Berry, 2013). A strong organizational image and identity also can create hysteresis that delays the divestment decision (Wan, Chen, \& Yiu, 2015).

Managerial constraints. Research on the growth of MNEs has provided corroborating empirical evidence that MNEs encounter managerial constraints when the Penrose effect occurs; that is, when a firm expands its operations more rapidly than its managers can administer the growth process effectively, the firm's growth rate is diminished in subsequent periods of time. Several empirical studies, some of which are explicitly based on Penrose's growth theory, corroborate the presence of the Penrose effect (Gao \& Pan, 2010; Hutzschenreuter et al., 2011). For example, Hashai (2011) finds that the geographical scope of expansion of international new ventures is associated negatively with their expansion in subsequent periods. Johanson and Kalinic's (2016) case-based research indicates that the growth process undergoes periods of acceleration and deceleration because it takes time and resources for firms to integrate and transform their experience into useful knowledge and routines. However, firms might be able to alleviate managerial constraints with organizational design and strategies. For example, Mayer, Stadler, and Hautz (2015) show that firms with substantial diversification experience can leverage the organizational and managerial mechanisms they developed in prior growth initiatives to achieve subsequent rapid expansion in both diversified product areas and international 
markets. As another relief to the Penrose effect, Tan (2009) finds that growth in the form of acquisition attenuates managerial constraint and enables faster growth than organic (greenfield) growth when the HQ and subsidiaries are weakly interdependent, such as in the case of multi-domestic industries or the codified transfer of knowledge. In addition, firm- and industry-level characteristics that facilitate managerial learning can attenuate the constraints on growth. For example, international experience enables firms to rapidly acquire and assimilate host-country knowledge and strengthen managerial ability to coordinate diverse foreign operations. As a result, firms with international experience are less vulnerable to the negative impact of internationalization at a faster rate (Hashai, 2011; Mohr et al., 2018). A stable industrial environment also makes it easier for managers to learn from their international experience, which enables their firms to achieve growth in subsequent periods (Tan \& Mahoney, 2007).

Some of the studies that examine the role of managerial constraints on internationalization focus on family firms. These studies identify the key constraints that hamper international growth, including over-reliance on family management, the pursuit of non-economic objectives, and differential treatment of family assets and non-family assets (Alessandri, Cerrato, \& Eddleston, 2018; Arregle, Duran, Hitt, \& van Essen, 2017; De Massis, Frattini, Majocchi, \& Piscitello, 2018; Kano \& Verbeke, 2018; Ray, Mondal, \& Ramachandran, 2018). Firms may alleviate some of these family-based constraints if they instill professionalism in the management and control (Kano \& Verbeke, 2018), are managed by later generations (Fang, Kotlar, Memili, Chrisman, \& De Massis, 2018), have foreign equity holding (Bhaumik, Driffield, \& Pal, 2010), or are located in countries in which the political ideology is aligned with their non-economic objectives (Duran, Kostova, \& van Essen, 2017). Family firms can also escape resource and managerial constraints by using a global niche business model in which an emphasis on global, standardized products and services alleviates the need for managerial efforts in addressing local responsiveness (Hennart, Majocchi, \& Forlani, 2019). In addition, the unique approach that family firms use to manage knowledge helps to alleviate managerial constraints. Specifically, compared to non-family firms, family firms do better at retaining the country-specific knowledge that they learned through international expansion (Tsang, 2020). As a result, they achieve greater innovation from internationalization (Tsao \& Lien, 2013).

Overall, research on the growth of MNEs provides insights concerning four key factors that constrain the 
growth of MNEs, i.e., (1) cross-country differences, (2) risk and uncertainty in host countries, (3) financial constraints, and (4) managerial constraints. Cross-country differences and uncertainties are shown to limit the growth of MNEs in host countries. However, from Penrose's lens, these (external) constraints do not have long-lasting impacts on the growth of the MNEs because there will always be profitable growth opportunities outside the host countries. These seemingly exogenous barriers to growth could be endogenized and overcome by internal factors, such as learning and entrepreneurial capabilities that can be influenced by the administrative and organizational design of MNEs. Indeed, the research on the growth of MNEs shows that constraints, such as cross-cultural differences, do not limit the growth of MNEs as a whole because managers can turn these differences into learning opportunities. This research also shows that firm-level resources and strategies (as managerial choices) can mitigate the negative impacts of external constraints.

\section{Trajectory of MNE Growth}

Several studies have described and explained the growth trajectory of multinational firms. This line of research, which often is based on internationalization process theory (Johanson \& Vahlne, 1977), suggests that growth involves an incremental learning and capability-building process. Initially, firms tend to enter their core businesses in a foreign market and then expand into non-core businesses (Chang, 1995; Chang \& Rosenzweig, 1998; Goerzen \& Makino, 2007). As an MNE gradually increases its portfolio of subsidiaries, it accumulates knowledge that enables a specific international growth pattern (Hutzschenreuter \& Matt, 2017). Therefore, a firm's initial sub-national entry location in a foreign market and its overall location portfolio influence its subsequent growth rate and choices of locations (Hutzschenreuter \& Harhoff, 2020; Nachum \& Song, 2011). MNEs that make path-breaking moves might experience both upside potential and downside risk, with the latter potentially resulting in an undesired exit (Santangelo \& Meyer, 2017).

Viewing the growth of MNEs as a learning and capability building process implies that MNEs have different challenges and thus require different supporting management activities over different stages of their growth (Birkinshaw, Ambos, \& Bouquet, 2017; Hendry, 1996; Li, Li, \& Dalgic, 2004). For example, Fisch (2008) finds that MNEs are more sensitive to the economic conditions of a host country during their first year in the market than they are in later years. Likewise, Chen (2003) report that network resources are particularly 
important in initial periods of international growth for Taiwanese electronic firms, which explains why these firms often start at locations close to the home base where support can be drawn from domestic networks. Over time, these firms build up their own foreign support networks and move to locations that are more distant. Thus, the evolving capabilities of MNEs influence their international growth patterns.

Studies also have suggested that the growth of MNEs might be a non-linear process. Sarkar, Cavusgil, and Aulakh (1999) report a discontinuous pattern in the internationalization of telecom carriers. Their study show that telecom firms initially made large commitments to foreign markets, but they slowed down before they embarked on another series of large expansions. Pedersen and Shaver (2011) also show a discontinuous process of international expansion for Danish firms. These firms initially took a long time to build a management infrastructure to support their first international investments, but subsequently they made investments in shorter periods of time. Maitland, Rose, and Nicholas (2005) suggest that clustering the timing of investments enables parent managers to reduce the administrative disruption that might be caused by establishing a new foreign subsidiary. Thus, various studies indicate the presence of both the Penrose effect and the learning curve effect in international growth.

In addition, a firm's growth in foreign markets is shown to be interdependent with other aspects of its strategy, such as product diversification. In particular, the relationship between international growth and growth via product diversification generally is substitutive (Bowen \& Sleuwaegen, 2017; Kumar, 2009; Kumar, Gaur, \& Pattnaik, 2012) with the exception of firms that have significant prior experience with diversification (Mayer et al., 2015). These interdependencies also influence the exit decisions of MNEs. For example, foreign subsidiaries that are not in the parent firm's core businesses tend to have a higher exit rate (Li, 1995). That said, in host countries with weak institutional environments, within-country product diversification could reduce the negative impact of market imperfections, thereby enhancing the growth of subsidiaries (Delios, $\mathrm{Xu}$, \& Beamish, 2008).

Overall, research that draws on Penrose, and research that does not, consider the growth of firms to be a learning or capability-building process, but these studies differ on the objects on managerial learning. Research that builds on Penrose's growth theory emphasizes managerial learning about the firm's resource and competency bases, 
while other studies emphasize managerial learning about foreign markets. Yet, the overall emphasis of the research on learning implies that the growth of a (multinational) firm essentially is based on the "cumulative growth of collective knowledge" (Penrose, 1995: xiii).

\section{Comparison between MNE Growth Research that Draws on Penrose's Theory and Research that Does Not}

Table 3 summarizes the comparison between the research on the growth of MNEs that draws on Penrose and the research that does not. We highlight a few commonalities and differences here. First, both types of research share a similar underpinning conceptualization by considering a firm as an administrative organization that relies on managers to oversee the use of resources. However, in Penrose's theory, 'what a firm is' explains 'how it grows.' The capacities of managers, who are characterized as indispensable in firms, constitute both facilitators and constraints of the growth of a firm. The availability of managers that have experiential knowledge of the firm's resources and capabilities is what enables growth because (1) this knowledge allows identification of the markets in which the firm's unique resources and advantages can be best leveraged, and (2) it enables managers to effectively coordinate the growth process by making critical decisions on the utilization, deployment, combining, and discarding of resources, as well as the creation of modified systems and strategies to integrate with markets in foreign territories. In comparison, MNE growth research that does not build on Penrose tends to treat 'how an MNE grows' and 'how an MNE functions as an administrative unit' in different research streams. This separation results in an incomplete understanding of the intricate process by which an MNE grows and achieves coordination. When the key drivers of international growth, such as underutilized, firm-specific resources, managers, experiential learning, and external conditions, are discussed and examined separately, the theory fails to capture the ultimate insight, which is the interactions and interlinkages among these drivers that make up the actual story of the growth of MNEs.

Second, both types of research identify a similar set of internal growth facilitators that include underutilized resources, managers, and learning. However, they also differ in terms of the emphasis on the types of managerial qualities and the objects of learning. Research that draws on Penrose's theory focuses on managerial knowledge about the firm and the resources, so it highlights the importance of managers' firm-specific learning as a result of resource-manager interactions during growth and experimentation. In comparison, research that does not draw on Penrose pays limited attention to firm-specific managerial experience and learning. Instead, it focuses primarily on 
managers' foreign market experience and incentives for achieving international growth. In the section on the direction of future research, we elaborate on the potential merits of incorporating in research the central role of firmspecific managerial learning for the growth of MNEs.

Third, in terms of the key constraints on the growth of MNEs, the two types of research have different points of focus. Research that does not draw on Penrose emphasizes external constraints, such as cross-country differences, which mirrors the importance it places on learning about foreign market conditions as a key facilitator of growth. This research aims to identify the firm's attributes and strategies that may mitigate the negative impact of external constraints. In comparison, in Penrose's theory, the external environment is perceived subjectively and could be influenced by managerial actions. A firm's failure to address unfavorable conditions in certain host countries reflects the lack of entrepreneurial abilities of its managers (such as the lack of ingenuity and entrepreneurial imagination). From this perspective, the firm's attributes and strategies that are useful in reducing the negative impact of external conditions can be conceptualized as part of the entrepreneurial capabilities of the firm. Accordingly, we highlighted new research opportunities based on a close consideration of the endogenous factors that drive international growth, as well as endogenizing some of the seemingly exogenous growth determinants.

Fourth, in terms of the trajectory of growth, there is significant convergence in insights produced by both types of research. Each type reports the path-dependent nature of international growth (going from core to non-core and from close to distant locations), and each type suggests that path-breaking growth patterns are more likely to result in an exit. The non-linear growth pattern reported by research (i.e., fast growth followed by slower growth) is consistent with the Penrose effect. Extending this idea, research that draws on Penrose also underscores the interdependent (substitutive) relationship between product and international diversification, where there is competition for resources (especially firm-specific managerial resources). Therefore, despite focusing on different resources that drive the path-dependency of the growth trajectory (i.e., firm-specific managerial resources vs. foreign markets), both research approaches view growth as an incremental learning and capability-building process. Firms can achieve a more successful growth trajectory in the long run, if they can map and sequence their growth initiatives based on both evolving managerial capabilities and foreign market expertise as well as the interdependencies among (existing and proposed) growth initiatives. 


\section{FUTURE RESEARCH DIRECTIONS}

In this section, we reflect on the review of the research on the growth of MNEs and suggest several future research opportunities. Table 4 summarizes some research inquiries from the reflection.

\section{Concepts of firms/MNEs - what constitutes the growth of MNEs?}

The growth of the MNE in its entirety.

Our review indicates that a major part of the findings on the determinants of the growth of MNEs is based on firms' entry and subsequent expansion/exit in a single host market. This is a critical gap because the entry and sequential expansion/exit of an MNE in one particular market explain only a fraction of the story of the growth of the MNE as a whole. We recommend theory development and empirical examination that capture the strategies and growth/performance of MNEs in their entirety (Cuervo-Cazurra, Mudambi, \& Pedersen, 2018), a few of which we highlight here. First, a multinational firm's decision to expand in or exit from a particular market is not determined solely by market- and subsidiary-specific conditions, but also by the conditions in other markets where the MNE operates. For example, the decision to enter or exit from a market might be a result of the MNE's purposeful configuration of its FDI locations to reduce the uncertainty associated with fluctuations in exchange rates and market growth (Song, Makhija, \& Lee, 2014). Here, a transaction-specific or market-specific focus provides only a partial understanding of the complex tradeoffs that the HQ of an MNE must consider in managing its global network of international initiatives.

Second, there are interdependencies among various international activities that involve entries into new markets, expansion, downsizing/downscoping, and exit (Vidal \& Mitchell, 2018). For example, expansionary (or downsizing/downscoping) activities require coordination by managers with firm-specific and hostcountry knowledge, including the deployment of their relational capital with internal and external constituents. A limited supply of experienced managers (and employees) creates a difficult to escape limit to the rate of growth and adjustment of the MNEs' global business activities (as predicted by the Penrose effect). As a result, future research can examine how MNEs manage interdependencies (positive and negative synergies) among their activities across different geographical locations and re-configure their foreign operations portfolio. This 
type of research involves moving away from a discrete approach that focuses on a single strategic choice at a point in time (Langley, Smallman, \& Tsoukas, 2013), to one that examines the sequencing and patterns of strategic moves and responses over time (Pettus, Kor, Mahoney, \& Michael, 2018).

Third, modern multinational firms often grow in both diversified product and geographical areas. Our review suggests that these two growth directions can be either substitutive or complementary in that product diversification can compete for HQ's resources with international expansion; at the same time, synergies between the two directions can yield competitive advantages that support and sustain profitable growth in various foreign markets. Future research can provide a more refined understanding of the costs and benefits of a sequential or simultaneous pursuit of these growth strategies, as well as the firm-specific and contextual contingencies that moderate their effects on growth.

\section{The nature of firms/MNEs (Implications from the Penrosean theory)}

In Penrose's growth theory, the assumption that firms are administrative organizations has direct implications for the key determinants of firm growth. That is, management runs firms, and could facilitate and constrain the rates of growth of firms (Penrose, 1995: xii). Here, the growth of a firm, including the determinants and pattern, is explained under a coherent theorizing framework. Research on MNE growth shares a similar notion of firms with Penrose and recognizes the role of managerial or administrative authority in decision-making within multinational firms. However, with a few exceptions (e.g., Buckley \& Casson, 2007; Pitelis, 2002; Teece, 2014), research has not systematically incorporated the nature of MNEs into a theory of growth for MNEs. There is an opportunity to build an internally coherent theory of the growth of MNEs, that is, a theory that connects 'what an MNE is' to 'what determines an MNE's growth.' Teece (2014) proposes that to build a general theory of MNEs, scholars should pay more attention to entrepreneurial management. This dynamic capabilities approach sees MNE activities as "driven by the opportunity to leverage capabilities and create and capture value from innovation on a global scale" (Teece, 2014: 22), and thus managers' ability to sense, shape, and exploit the opportunities is crucial to the long-term competitiveness of MNEs in changing global environments.

From the Penrosean perspective, future studies can further explore the role of managerial authority and coordination within MNEs. Research on the growth of MNEs has examined the role of managers' foreign 
experience and relational capital in facilitating growth, but these two research areas are worthy of further investigation. First, research can pay more attention to firm-specific managerial learning. Firm-specific knowledge is important for MNEs to achieve coordination and synergies among geographically dispersed and goal-disparate organizations (Ghoshal \& Bartlett, 1990). Some of the early IB research has illustrated examples of firm-specific managerial knowledge within MNEs and its effects. For example, a shared understanding of the MNE's values (Nohria \& Ghoshal, 1994) and objectives (Kuemmerle, 1997), and the knowledge about individual subsidiaries (Birkinshaw \& Morrison, 1995) improve coordination within the MNE. Managers' relationships with other subsidiary managers within the multinational network facilitate knowledge sharing and contribute to the collective gain of the MNEs (Kostova \& Roth, 2003). Recent studies examine the functions of HQ and regional HQ in coordinating subsidiaries (Belderbos, Du, \& Goerzen, 2017; Birkinshaw et al., 2017; Buckley, 2009). Building on this early and recent work, we ask two research questions: (1) What constitutes HQ-level capabilities to achieve effective control and coordination within a multinational network? (2) How do firm-specific knowledge and social capital relate to these capabilities? We see value in future research that further examines the role and impact of firmspecific managerial knowledge (which might be embedded in regional or general HQs and subsidiaries), and how such managerial knowledge can be cultivated across an MNE's global network.

Second, managerial capabilities must be joined with incentives to achieve MNE growth. Research on MNE growth has captured the importance of managers' foreign experience, but underexplored the adverse role of management in shaping the growth of MNEs. The boundaries of managerial authority in organizing resources constitute a major reason why contractual or hybrid forms of resource exchange sometimes are chosen over hierarchy (Hennart, 1993). However, MNE growth research has paid limited attention to how managerial opportunism can constrain the growth of MNEs (Hoenen \& Kostova, 2015). Managerial opportunism in MNEs can occur at both the subsidiaryand HQ-levels. Subsidiary-level managerial opportunism can increase with the pressure for local responsiveness, which motivates subsidiaries to accumulate host-country knowledge and develop their own competences (Andersson, Forsgren, \& Holm, 2007). As a result, subsidiaries gain increasing bargaining power that enables them to seek economic rents within the multinational firms (Mudambi \& Navarra, 2004) and to use dysfunctional conflict and negotiation tactics against the HQ (Schotter \& Beamish, 2011). The HQ's lack of host-country knowledge limits 
its ability to monitor and control. For example, Holm, Decreton, Nell, and Klopf (2017) report that subsidiary managers tend to postpone their response to HQ's requests when they are incongruent with the host-country environment. Thus, effective control and coordination require HQ's managers to gain access to subsidiary-specific knowledge. In terms of the knowledge required for subsidiary-level managers, even though Penrose (1959) did not focus on managerial opportunism, her theory informs us about the value of firm (HQ)-specific knowledge for subsidiary managers. Investing in the human capital of subsidiary managers and promoting their understanding of the HQ's strategic framework not only help to mitigate subsidiary-level managerial opportunism, but also result in superior strategy and system design for growth. We see value in research on how the growth of MNEs is affected by subsidiary-level managerial opportunism.

Further, HQ-level managerial opportunism is an agency problem in that managers act in their own interests, such as pursuing international growth with empire-building motives. Extensive research on the relationship between multinationality and performance suggests that MNEs experience financial loss when their foreign presence exceeds a certain threshold. However, MNEs typically operate in global industries in which size can yield scale advantages and legitimacy in the long run, especially for firms in weak institutional environments. Therefore, the long-term performance consequences of empire-building driven growth remain an empirical question.

\section{Facilitators of MNE growth}

In this review, we drew on research on foreign market entry and subsidiary expansion to identify the facilitators of MNE growth. However, do facilitators of initial entry into a host market also enhance MNE's subsequent growth in the particular market? It is reasonable to expect that firm-specific advantages such as $R \& D$ capabilities promote both new market entry and subsidiary sequential growth, as knowledge-based resources have long-lasting positive impacts on international growth (Tseng et al., 2007). However, for other facilitators, the answer might not be as clear. For example, research indicates that ethnic ties might help to initiate a firm's entry into a new market, but it is unclear whether such ties can guarantee long-term success in the market.

We also see value in research on the long-term growth of MNEs, including divestments and exits, as potential corrections to their evolving growth strategy. This research can investigate the environmental and organizational factors that promote post-entry growth in foreign markets. In this inquiry, research might benefit 
from the dynamic capabilities approach (Petricevic \& Teece, 2019; Teece, 2014), which highlights the importance of responsiveness to external changes. While changes frequently occur in product markets, for MNEs, external changes also arise from fluctuations in the host country's (geographical) conditions and unexpected shocks from sociopolitical and institutional environments. Our review indicates that some firms effectively develop capabilities and adjust their location and equity portfolios to respond to external changes (Vahlne \& Ivarsson, 2014). Future research can examine what constitutes an MNE's dynamic capability to deal with host-country uncertainties and sustain growth in ever-changing foreign markets.

As part of MNEs' dynamic capabilities, there is also a need for more refined research on dynamic managerial qualities (Kor \& Mesko, 2013) that facilitate the growth of MNEs. We note two research opportunities in particular. First, international diversification is an important solution to address stagnant growth in particular host markets. This type of growth often requires the presence of entrepreneurial competence in the HQ and subsidiaries (Birkinshaw, 2000; Teece, 2014), which comes in the form of ambition and ability to initiate proposals for exploring new geographical areas (Penrose, 1959: 183). Penrose further suggests that entrepreneurial competence is a "necessary (though not sufficient) condition for continued growth," (1959: 8) because identifying the right set of opportunities, and implementing a growth plan, also requires managerial competence. Administrative competence involves effective coordination that reflects an intimate understanding of the firm's capabilities as well as thorough knowledge of host-country conditions. We see value in research that identifies, measures, and examines entrepreneurial and administrative competencies, including their synergistic effects on MNE growth. Such research can investigate the roles of both firm-specific, and 'cosmopolitan and diverse' experiences in shaping the entrepreneurial and administrative (execution) capabilities of managers. This research can also capture practices, processes, and challenges in recruiting and developing such dynamic managerial capabilities in MNEs (Teece, 2014).

As an example, some coordination and cooperation challenges attributed to subsidiary management stem from a lack of understanding by subsidiary managers of corporate strategies and practices, and from HQ managers' insufficient knowledge of host-country conditions. Here, a co-creation or team entrepreneurship model (Foss, Klein, Kor, \& Mahoney, 2008) might be preferable when the MNE needs to adapt to host-country conditions. This type of 
collaboration requires shared, experiential (tacit) knowledge of both corporate and subsidiary domains, emphasizing the importance of visits, interactions, and training for the launch of growth initiatives. It might also involve HQ managers developing a versatile portfolio of experiences for a pluralistic understanding of different markets and gaining cross-cultural skills. Managerial skills in the forms of empathy, effective communication, and relationshipbuilding can be relevant in promoting mutual trust and collaboration. An appreciation of different expectations about teamwork and collaboration (horizontally and vertically) is important, as individuals in different nations and organizational contexts are likely to hold substantially different interpretations (Gibson \& Zellmer-Bruhn, 2001).

Relatedly, our review finds that the majority of research focused on HQ-level managers, and there is limited research on the influence of subsidiary-level managers on the growth of the MNEs. This is a critical gap because subsidiary-level managers play a key role in host-country learning. Their capabilities and incentives influence the development of host-country knowledge and its transfer to other units (including HQ), thereby contributing to the growth of the MNEs. Future research might draw on the extensive research on expatriates and enhance the understanding of MNE growth.

In addition, our review finds that while Penrose-inspired research focused on direct learning, other research emphasized the importance of indirect learning, i.e., observing or interacting with other firms that have experience in the host country. Direct and indirect learning can be complementary. Relying exclusively on direct learning can put a limit on how much managers and organizations can "experience." Research indicates that established routines and internally institutionalized norms can make it harder for firms to adjust to cross-country differences when they grow. Indirect learning from business partners, subsidiaries, and outside board members/advisors can help to weaken the inertia tendencies and expand managerial vision and the growth opportunity set for the firm. The importance of indirect (often externally-sourced) learning underscores the importance of developing capabilities and systems for the firm to effectively learn from partnerships, subsidiaries, and other relationships and become good at disseminating knowledge across the MNE network. However, these new insights still need to be combined with firm-specific knowledge on how to leverage and mobilize the firm's unique resources. Therefore, the firm also needs to develop ways to integrate firm-specific knowledge and indirectly acquired knowledge to produce the most synergistic growth outcomes. While indirect learning expands the learning repertoire of the firm, applying others' 
experience without infusing it with the experiential knowledge of how the firm's unique resources can become a blindfold approach to international growth. Future research can explore the relationships between direct hostcountry experience, indirect experience, and firm-specific experience and their impacts on MNE growth.

\section{Constraints on MNE growth}

Our review reveals that many studies that discuss the constraints on MNE growth also examine the conditions that alleviate these constraints. Some external constraints on MNE growth (such as cross-country differences and risk/uncertainty) can be attributed to insufficient host-country knowledge and insufficient entrepreneurial capabilities on the part of the MNEs. Thus, the binding constraint of MNE growth might originate from the (lack of) organizational design and mechanisms for the acquisition and assimilation of host-country knowledge, as well as entrepreneurial initiatives. Given that such design and mechanism were discussed in other research streams such as organizational learning, knowledge management, and subsidiary initiatives, incorporating these research streams might advance the research on MNE growth.

Our review corroborates the prevalence of managerial constraints on MNE growth, which arise from the need for close administrative coordination in the growth process. In this situation, can MNEs use autonomous organizational structures to reduce the need for coordination and thus escape managerial constraints? Given current intensified pressure for local responsiveness, it might be difficult or even unnecessary to impose managerial systems that originate from the HQ on foreign subsidiaries (Doz \& Prahalad, 1981; Meyer, Mudambi, \& Narula, 2011). This issue might be rooted in the central concern of internalization theory of FDI regarding the tradeoff between control and incentives (Hennart, 1993; Rugman \& Verbeke, 2003) and in the classic debate of a tradeoff between global integration and local responsiveness (Roth \& Morrison, 1990). Wang, Luo, Lu, Sun, and Maksimov (2014) report that Chinese multinational firms give autonomy to their foreign subsidiaries to overcome their insufficiencies in host-country experience and capabilities. Zellmer-Bruhn and Gibson (2006) show that a departure from globally integrated models towards subsidiary-driven local responsiveness increases learning and performance in team settings. However, would delegating key value-creation functions to subsidiaries result in loss of control in the MNE's firm-level learning of knowledge bases that are required to propel long-term growth? Would it propel agency problems and make the MNE captive to subsidiary managers with specialized knowledge? Alternatively, would an 
autonomous structure help foster subsidiary capabilities and create spillover-learning effects for the MNE? When do these possibilities become prevalent? Can a co-creation or team-entrepreneurship model be an alternative where some subsidiary autonomy is combined with the close but collaborative engagement of MNE managers, allowing a two-way information flow and synergistic problem solving? These theoretical and empirical questions are good candidates for the next generation of research on MNE growth.

Relatedly, potential agency problems in HQ-subsidiary relationships highlight a more significant underpinning issue about the growth boundaries of MNEs. Penrose (1959) embraced a resource-driven growth strategy in which the firm's bundle of resources and capabilities serve as the key driver of growth, and this approach preserves the company's strategic coherence (Teece et al., 1994). The Penrosean theory excludes companies that are led by empire-building ambitions that pay little attention to the path-dependent nature of organizational learning and firm-specific competency development. Penrose's theory posits that new growth occurs because the firm intends to join existing capabilities with new ones to compete in new domains. However, in the past few decades, the emergence of new (lucrative) markets around the globe has offered timebased competition and opportunities that require risky early moves (market entry) and strategic investments that involve steep organizational learning and limited leveraging of existing competencies. Likewise, companies have been faced with demands from their customers and business partners to expand into a range of foreign markets; failing to do so has meant a loss of core customers and business. Consequently, and even in the absence of empire-building ambitions, the boundaries of Penrose's 'coherent' corporation have been stretched substantially (Kor, Mahoney, \& Tan, 2020). In some cases, these bold growth initiatives have enabled MNEs to develop dynamic capabilities and successfully operate in multiple markets. In other cases, they have resulted in increased agency problems in HQ-subsidiary relationships, loss of HQ power and control, tarnished reputations, and the loss of competitive positions, when opportunity-driven (or imposed) market entry and investments were followed by painful exits in subsequent years. Therefore, today's MNEs face a challenge of losing strategic coherence as the strategies, business models, and dominant logics adopted across markets have proliferated (Farjoun, 2007). These developments in part explain the reduced overall FDI rates by MNEs in the past decade and the MNEs' search for a revised growth strategy that may bring more sustainable advantages. 
It might be that MNEs are starting to pivot back to a more Penrosean growth strategy based on strategic coherence. Future research can further explore how MNE growth and broader governance systems address the issue of eroding strategic coherence and its consequences.

\section{Moderators of MNE growth}

Our review identifies a number of studies that uncover the presence of interaction effects among managerial, firm-level, and environmental characteristics. A systematic examination of these interactions may involve multilevel models that might be data-intensive (Peterson, Arregle, \& Martin, 2012). We encourage scholars to collect the data and help improve our understanding of the complex interplay among individual-, firm-, and environment-level factors. A potential direction for modeling such interaction effects is to consider how managerial characteristics, such as their entrepreneurial proclivity, experiences, and incentives, join with firmlevel resources to impact international growth. Penrose (1959) suggests that effective utilization of firm-level resources depends on managers' entrepreneurial vision and firm-specific knowledge of the unique resources within the firm. Firm-level experience also yields little learning without managerial intention to learn (Hutzschenreuter, Pedersen, \& Volberda, 2007), which in turn can be influenced by external environments and firm-level corporate governance mechanisms. Future research can explore the dynamic interactions among managerial, firm-level, and environmental characteristics and their effects on MNE growth.

\section{Trajectory of MNE growth}

Earlier, we discussed the importance of examining the growth of MNEs in its entirety, such as considering the MNE's entire network of international activities to explain and predict a particular entry/expansion decision. There are interdependencies among different growth decisions in which sequential (multi-step) actions create a pattern of MNE growth. Some of the steps include corrections to overall growth strategy as the MNE learns from its growth efforts and renegotiates its competitive position under changing market conditions. The plurality of growth moves underscores the importance of contracting (de-growth) decisions such as divestment/exit and downsizing/downscoping as much as the expansionary moves, even though much MNE growth research has focused on the latter. Contracting might release resources for subsequent growth and contribute to learning, and the interplay between growth and contracting patterns is important for discovering what a 
dynamic growth capability might constitute for MNEs.

MNE growth research and Penrose's theory emphasize the importance of learning, which serves as an engine for growth; in a feedback loop, growth yields new learning and knowledge accumulation. Accordingly, innovation in MNEs is a key source of growth, which should be incorporated into the theory of the growth of MNEs (Buckley \& Casson, 2007). That said, innovation and learning activities might compete with international and product diversification for firm-level resources, such as managerial and employee resources. Despite synergies, there might be tradeoffs in pursuing diversification, internationalization, and innovation activities. How these positive and negative synergies emerge, enact, and drive organizational outcomes awaits research attention. As an example, Kor et al. (2016) provide a formal Penrosean model of the interplay and tradeoffs among key activities of production, training, and innovation where the availability of experienced managerial resources serves as a bottleneck.

Finally, our review also suggests a need for additional research that traces the evolution of MNEs over multiple stages of growth as early research was based mostly on mature companies. The recent rise of international new ventures and MNEs in emerging economies provides opportunities to observe and examine a new generation of "growing" multinationals. As MNEs are likely to encounter unique internal and external challenges in different stages of firm development, new research can generate insights into the process and management of growth of "younger" MNEs.

\section{MANAGERIAL AND SOCIAL IMPLICATIONS}

Based on our review of international business research, we identify important implications for policymakers and business practitioners. In particular, our review of the relevant research suggests that managers play a key role in planning and executing the international expansion of MNEs, and that their experiential learning has direct and indirect positive impacts on the growth of MNEs. Experiential learning directly facilitates MNE growth by enabling development of foreign market knowledge and international management skills. It also indirectly enhances growth by mitigating external constraints such as political risk, indicating the importance of designing an administrative structure and processes that encourages managerial learning and development.

Specifically, we highlight the need for international managers who have both breadth and depth in 
experience. Some subsidiary managers might spend their careers specializing in a country or a regional domain, but they might benefit from a broader understanding of MNEs' growth strategy that includes a range of markets. Regular immersion experiences for these managers (e.g., via retreats and HQ visits) can promote development of their firm-specific human capital, cultivate synergies across subsidiaries or regions, and socialize managers with MNE's evolving values, priories, and directions under new leadership and market conditions.

Likewise, developing managers with a variety of experiential opportunities creates a stronger pipeline of executives who can take on important roles at the HQ levels in MNEs (Carpenter, Sanders, \& Gregersen, 2001). Headquarters managers involved in shaping MNEs' growth decisions should have prior exposure to challenges in multiple markets. Multi-country exposure can sharpen managers' ability to detect and evaluate new opportunities (entrepreneurial skills) and oversee new initiatives (execution skills). HQ managers who lose touch with the realities of various global markets have diminished credibility (and influence) when they interact with subsidiary managers who possess host-country expertise. As the gap between home and hostcountry conditions widens, a new synthesis of MNEs' established strategy and host-country expertise is required. This new synthesis requires a shared understanding of both MNE strategy and host-country conditions.

Finally, due to space limitation, this review does not cover research on the impact of MNEs on host economies and societies, but we acknowledge that MNEs have a substantial influence on world economies and the well-being of people. These impacts suggest the need for an ongoing self-audit of their 'footprints,' i.e., their intended and unintended impacts on businesses, communities, and people's livelihood and cultural experiences of host countries. Given their global reach and resource and capability foundation, MNEs have the potential to create positive externalities such as knowledge spillovers and employment opportunities. Yet, some of the negative cascading effects of MNE growth, such as the effects of eliminating traditional products or methods, are not always easy to foresee, and some effects take years to unfold or to be understood. Due to the magnitude of their impact, MNEs bear a responsibility to take a more sophisticated approach to decision making, including their corporate-level (e.g., market entry-exit) and product-level decisions (e.g., sourcing and pricing). We are not convinced that the sophistication of the MNEs decision and control systems is at par with the complexity of the product and geographical scope firms embrace. This gap between the two is significant 
and concerning. One might argue that externalities produced by MNEs may ultimately even threaten their own existence. Scholars can play a vital role here by investigating and critically discussing the ongoing growth and evolution of MNEs with a close eye on their broad range of consequences.

\section{CONCLUSION}

Research on foreign market entry, sequential expansion, and divestment of multinational firms provides substantial insights into the growth of multinational firms. In this review, we have drawn on extensive but scattered research to identify major facilitators and constraints for the growth of the MNEs, and reviewed these findings through the lens of Penrosean growth theory. We recommended several future research directions, and, in particular, encouraged scholars to examine the growth and strategies of an MNE in its entirety and to consider further the role of management in explaining both the existence and the growth of the multinational firm. By so doing, we hope to improve both the scientific rigor and practical relevance of our understanding of the growth of a multinational firm as a whole. 


\section{REFERENCES}

Abebe, M.T., \& Begum, M. 2016. The spillover effect of MNCs on local firms: Reviewing the empirical evidence. International Research Journal of Engineering and Technology, 3(5): 2029-2043.

Adner, R., \& Helfat, C.E. 2003. Corporate effects and dynamic managerial capabilities. Strategic Management Journal, 24(10): 1011-1025.

Agnihotri, A., \& Bhattacharya, S. 2019. CEO narcissism and internationalization by Indian firms. Management International Review, 59(6): 889-918.

Albino-Pimentel, J., Dussauge, P., \& Shaver, J.M. 2018. Firm non-market capabilities and the effect of supranational institutional safeguards on the location choice of international investments. Strategic Management Journal, 39(10): 2770-2793.

Alessandri, T.M., Cerrato, D., \& Eddleston, K.A. 2018. The mixed gamble of internationalization in family and nonfamily firms: The moderating role of organizational slack. Global Strategy Journal, 8(1): 46-72.

Andersson, U., Forsgren, M., \& Holm, U. 2007. Balancing subsidiary influence in the federative MNC: A business network view. Journal of International Business Studies, 38(5): 802-18.

Arregle, J.-L., Duran, P., Hitt, M.A., \& van Essen, M. 2017. Why is family firms' internationalization unique? A meta-analysis. Entrepreneurship Theory and Practice, 41(5): 801-831.

Arregle, J.-L., Miller, T.L., Hitt, M.A., \& Beamish, P.W. 2016. How does regional institutional complexity affect MNE internationalization? Journal of International Business Studies, 47(6): 697-722.

Athanassiou, N., \& Nigh, D. 2002. The impact of the top management team's international business experience on the firm's internationalization: Social networks at work. Management International Review, 42(2): 157-181.

Augier, M., \& Teece, D.J. 2007. Dynamic capabilities and multinational enterprise: Penrosean insights and omissions. Management International Review, 47(2): 175-192.

Bai, T., Chen, S., \& He, X. 2019. How home-country political connections influence the internationalization of service firms. Management International Review, 59(4): 541-560.

Banerji, K., \& Sambharya, R. B. 1996. Vertical keiretsu and international market entry: The case of the Japanese automobile ancillary industry. Journal of International Business Studies, 27(1): 89-113.

Barkema, H.G., Bell, J.H.J., \& Pennings, J.M. 1996. Foreign entry, cultural barriers, and learning. Strategic Management Journal, 17(2): 151-166.

Barkema, H.G., \& Shvyrkov, O. 2007. Does top management team diversity promote or hamper foreign expansion? Strategic Management Journal, 28(7): 663-680.

Barnard, C.I. 1938. The Functions of the Executive. Cambridge, MA: Harvard University Press.

Belderbos, R., Du, H.S., \& Goerzen, A. 2017. Global cities, connectivity, and the location choice of MNC regional headquarters. Journal of Management Studies, 54(8): 1271-1302.

Belderbos, R., \& Zou, J. 2007. On the growth of foreign affiliates: multinational plant networks, joint ventures, and flexibility. Journal of International Business Studies, 38(7): 1095-1112.

Belderbos, R., \& Zou, J. 2009. Real options and foreign affiliate divestments: A portfolio perspective. Journal of International Business Studies, 40(4): 600-620.

Berry, H. 2013. When do firms divest foreign operations? Organization Science, 24(1): 246-261.

Berry, H., Guillén, M.F., \& Zhou, N. 2010. An institutional approach to cross-national distance. Journal of International Business Studies, 41(9): 1460-1480.

Bertrand, O., Betschinger, M.A., \& Laamanen, T. 2019. Effects of subnational regional corruption on growth strategies in emerging economies: Evidence from Russian domestic and international M\&A activity. Global Strategy Journal, 9(2): 303-332.

Beugelsdijk, S., Kostova, T., Kunst, V.E., Spadafora, E., \& van Essen, M. 2018. Cultural distance and firm internationalization: A meta-analytical review and theoretical implications. Journal of Management, 44(1): 89-130.

Bhaumik, S.K., Driffield, N., \& Pal, S. 2010. Does ownership structure of emerging-market firms affect their outward FDI? The case of the Indian automotive and pharmaceutical sectors. Journal of International Business Studies, 41(3): 437-450.

Bingham, C.B., \& Davis, J.P., 2012. Learning sequences: Their existence, effect, and evolution. Academy of Management Journal, 55(3): 611-641.

Birkinshaw, J. 1997. Entrepreneurship in multinational corporations: The characteristics of subsidiary initiatives. Strategic Management Journal, 18(3): 207-229.

Birkinshaw, J. 2000. Entrepreneurship in the Global Firm. Thousand Oaks, CA: Sage Publications.

Birkinshaw, J., Ambos, T.C., \& Bouquet, C. 2017. Boundary spanning activities of corporate HQ executives' insights from a longitudinal study. Journal of Management Studies, 54(4): 422-454.

Birkinshaw, J., \& Hood, N. 1998. Multinational subsidiary evolution: Capability and charter change in foreignowned subsidiary companies. Academy of Management Review, 23(4): 773-795. 
Birkinshaw, J., \& Morrison, A.J. 1995. Configurations of strategy and structure in subsidiaries of multinational corporations. Journal of International Business Studies, 26(4): 729-753.

Bowen, H.P., \& Sleuwaegen, L. 2017. Are international and product diversification substitutes or complements? Theoretical and empirical perspectives. Global Strategy Journal, 7(3): 241-256.

Bowman, E.H., \& Hurry, D. 1993. Strategy through the option lens: An integrated view of resource investments and the incremental-choice process. Academy of Management Review, 18(4): 760-782.

Boyacigiller, N. 1990. The role of expatriates in the management of interdependence complexity and risk in multinational corporations. Journal of International Business Studies, 21(3): 357-381.

Brouthers, K.D., \& Hennart, J.F. 2007. Boundaries of the firm: Insights from international entry mode research. Journal of Management, 33(3): 395-425.

Buckley, P.J. 2009. Internalisation thinking: From the multinational enterprise to the global factory. International Business Review, 18(3): 224-235.

Buckley, P.J., \& Casson, M. 1976. The Future of the Multinational Enterprise. London, UK: Macmillan.

Buckley, P.J., \& Casson, M. 2007. Edith Penrose's Theory of the Growth of the Firm and the strategic management of multinational enterprises. Management International Review, 47(2): 151-173.

Buckley, P.J., Chen, L., Clegg, L.J., \& Voss, H. 2020. The role of endogenous and exogenous risk in FDI entry choices. Journal of World Business, advance online publication February 7. https://doi.org/10.1016/j.jwb.2019.101040

Cantwell, J. 1989. Technological Innovation and Multinational Corporations. Oxford, UK: Blackwell.

Cantwell, J. 2009. Location and the multinational enterprise. Journal of International Business Studies, 40(1): 35-41.

Cantwell, J., Dunning, J.H., \& Lundan, S.M. 2010. An evolutionary approach to understanding international business activity: The co-evolution of MNEs and the institutional environment. Journal of International Business Studies, 41(4): 567-586.

Cantwell, J., \& Mudambi, R. 2005. MNE competence-creating subsidiary mandates. Strategic Management Journal, 26(12): 1109-1128.

Carpenter, M.A., \& Fredrickson, J.W. 2001. Top management teams, global strategic posture, and the moderating role of uncertainty. Academy of Management Journal, 44(3): 533-545.

Carpenter, M.A., Sanders, W.G., \& Gregersen, H.B. 2001. Bundling human capital with organizational context: The impact of international assignment experience on multinational firm performance and CEO pay. Academy of Management Journal, 44(3): 493-512.

Casillas, J.C., \& Moreno-Menendez, A.M. 2014. Speed of the internationalization process: The role of diversity and depth in experiential learning. Journal of International Business Studies, 45(1): 85-101.

Caves, R.E. 1971. International corporations: The industrial economics of foreign investment. Economica, 38(149): 1-27.

Cesinger, B., Hughes, M., Mensching, H., Bouncken, R., Fredrich, V., \& Kraus, S. 2016. A socioemotional wealth perspective on how collaboration intensity, trust, and international market knowledge affect family firms' multinationality. Journal of World Business, 51(4): 586-599.

Chan, C. M., Makino, S., \& Isobe, T. 2006. Interdependent behavior in foreign direct investment: The multilevel effects of prior entry and prior exit on foreign market entry. Journal of International Business Studies, 37(5): 642-665.

Chang, S. J. 1995. International expansion strategy of Japanese firms: Capability building through sequential entry. Academy of Management Journal, 38(2): 383-407.

Chang, S. J. 1996. An evolutionary perspective on diversification and corporate restructuring: Entry, exit, and economic performance during 1981-89. Strategic Management Journal, 17(8): 587-611.

Chang, S.J., \& Rosenzweig, P.M. 1998. Industry and regional patterns in sequential foreign market entry. Journal of Management Studies, 35(6): 797-822.

Chen, H.-L., Chang, C.-Y., \& Hsu, W.-T. 2017. Does board co-working experience influence directors' decisions toward internationalization? Management International Review, 57(1): 65-92.

Chen, L., Li, Y., \& Fan, D. 2018. How do emerging multinationals configure political connections across institutional contexts? Global Strategy Journal, 8(3): 447-470.

Chen, T. J. 2003. Network resources for internationalization: The case of Taiwan's electronics firms. Journal of Management Studies, 40(5): 1107-1130.

Chi, T. 1994. Trading in strategic resources: Necessary conditions, transaction cost problems, and choice of exchange structure. Strategic Management Journal, 15(4): 271-290.

Chi, T., Li, J., Trigeorgis, L.G., \& Tsekrekos, A.E. 2019. Real options theory in international business. Journal of International Business Studies, 50(4): 525-553.

Chittoor, R., Aulakh, P.S., \& Ray, S. 2019. Microfoundations of firm internationalization: The owner CEO effect. Global Strategy Journal, 9(1): 42-65. 
Chung, C.C., Lee, S. H., Beamish, P.W., \& Isobe, T. 2010. Subsidiary expansion/contraction during times of economic crisis. Journal of International Business Studies, 41(3): 500-516.

Chung, C.C., Lee, S.-H., \& Lee, J.-Y. 2013. Dual-option subsidiaries and exit decisions during times of economic crisis. Management International Review, 53(4): 555-577.

Coviello, N.E., \& McAuley, A. 1999. Internationalisation and the smaller firm: A review of contemporary empirical research. Management International Review, 39(3): 223-256.

Cuervo-Cazurra, A., \& Genc, M. 2008. Transforming disadvantages into advantages: Developing-country MNEs in the least developed countries. Journal of International Business Studies, 39(6): 957-979.

Cuervo-Cazurra, A., Maloney, M.M., \& Manrakhan, S. 2007. Causes of the difficulties in internationalization. Journal of International Business Studies, 38(5): 709-725.

Cuervo-Cazurra, A., Mudambi, R., \& Pedersen, T. 2018. The boundaries of the firm in global strategy. Global Strategy Journal, 8(2): 211-219.

Cui, L., Li, Y., Meyer, K.E., \& Li, Z. 2015. Leadership experience meets ownership structure: Returnee managers and internationalization of emerging economy firms. Management International Review, 55(3): 355-387.

Dagnino, G.B., Giachetti, C., La Rocca, M., \& Picone, P.M. 2019. Behind the curtain of international diversification: An agency theory perspective. Global Strategy Journal, 9(4): 555-594.

Dai, L., Eden, L., \& Beamish, P.W. 2013. Place, space, and geographical exposure: Foreign subsidiary survival in conflict zones. Journal of International Business Studies, 44(6): 554-578.

Dai, L., Eden, L., \& Beamish, P.W. 2017. Caught in the crossfire: Dimensions of vulnerability and foreign multinationals' exit from war-afflicted countries. Strategic Management Journal, 38(7): 1478-1498.

Dau, L. A. 2012. Pro-market reforms and developing country multinational corporations: Reforms and DMNCs. Global Strategy Journal, 2(3): 262-276.

Delios, A., \& Beamish, P.W. 1999. Geographic scope, product diversification, and the corporate performance of Japanese firms. Strategic Management Journal, 20(8): 711-727.

Delios, A., \& Beamish, P.W. 2001. Survival and profitability: The roles of experience and intangible assets in foreign subsidiary performance. Academy of Management Journal, 44(5): 1028-1038.

Delios, A., \& Henisz, W.J. 2003a. Policy uncertainty and the sequence of entry by Japanese firms, 1980-1998. Journal of International Business Studies, 34(3): 227-241.

Delios, A., \& Henisz, WJ. 2003b. Political hazards, experience, and sequential entry strategies: The international expansion of Japanese firms, 1980-1998. Strategic Management Journal, 24(11): 1153-1164.

Delios, A., Xu, D., \& Beamish, P.W. 2008. Within-country product diversification and foreign subsidiary performance. Journal of International Business Studies, 39(4): 706-724.

De Massis, A., Frattini, F., Majocchi, A., \& Piscitello, L. 2018. Family firms in the global economy: Toward a deeper understanding of internationalization determinants, processes, and outcomes. Global Strategy Journal, 8(1): 3-21.

Demirbag, M., Apaydin, M., \& Tatoglu, E. 2011. Survival of Japanese subsidiaries in the Middle East and North Africa. Journal of World Business, 46(4): 411-425.

Dhanaraj, C., \& Beamish, P.W. 2009. Institutional environment and subsidiary survival. Management International Review, 49(3): 291-312.

Dixit, A.K. \& Pindyck, R.S. 1994. Investment under Uncertainty. Princeton, NJ: Princeton University Press.

Dow, D., Liesch, P., \& Welch, L. 2018. Inertia and managerial intentionality: Extending the Uppsala model. Management International Review, 58(3): 465-493.

Dowell, G., \& Killaly, B. 2009. Effect of resource variation and firm experience on market entry decisions: Evidence from US telecommunication firms' international expansion decisions. Organization Science, 20(1): 69-84.

Doz, Y. L., \& Prahalad, C.K. 1981. Headquarters influence and strategic control in MNCs. Sloan Management Review, 23(1): 15-29.

Dunning, J. H. 1979. Explaining patterns of international production: In defense of the eclectic theory. Oxford Bulletin of Economics and Statistics, 41(4): 269-295.

Dunning, J. H. 1980. Toward an eclectic theory of international production: Some empirical tests. Journal of International Business Studies, 11(1): 9-31.

Dunning, J. H. 1993. Multinational Enterprises and the Global Economy. Wokingham, U.K: Addison-Wesley.

Dunning, J. H. 2003. The contribution of Edith Penrose to international business scholarship. Management International Review, 43(1): 3-19.

Dunning, J. H., \& Kundu, S.K. 1995. The internationalization of the hotel industry: Some new findings from a field study. Management International Review, 35(2): 101-133.

Dunning, J. H., \& Lundan, S.M. 2008. Multinational Enterprises and the Global Economy. Cheltenham, UK: Edward Elgar Publishing. 
Duran, P., Kostova, T., \& van Essen, M. 2017. Political ideologies and the internationalization of familycontrolled firms. Journal of World Business, 52(4): 474-488.

Edström, A. \& Galbraith, J.R., 1977. Transfer of managers as a coordination and control strategy in multinational organizations. Administrative Science Quarterly, 22(2): 248-263.

Eriksson, K., Johanson, J., Majkgård, A., \& Sharma, D.D. 1997. Experimental Knowledge and Costs in the Internationalization Process. Journal of International Business Studies, 28(2): 337-360.

Estrin, S., Meyer, K.E., Nielsen, B.B., \& Nielsen, S. 2016. Home country institutions and the internationalization of state owned enterprises: A cross-country analysis. Journal of World Business, 51(2): 294-307.

Fang, H., Kotlar, J., Memili, E., Chrisman, J.J., \& De Massis, A. 2018. The pursuit of international opportunities in family firms: Generational differences and the role of knowledge-based resources. Global Strategy Journal, 8(1): 136-157.

Farjoun, M. 2007. The end of strategy. Strategic Organization, 5(3): 197-210.

Fathallah, R., Branzei, O., \& Schaan, J.L., 2018. No place like home? How EMNCs from hyper-turbulent contexts internationalize by sequentially arbitraging rents, values, and scales abroad. Journal of World Business, 53(5): 620-631.

Fernandez-Mendez, L., Garcia-Canal, E., \& Guillén, M.F. 2018. Domestic political connections and international expansion: It's not only "who you know" that matters. Journal of World Business, 53(5): 695-711.

Fernández-Méndez, L., García-Canal, E., \& Guillén, M.F. 2019. Power transitions in the host country and the survival of subsidiaries in infrastructure industries. Global Strategy Journal, 9(2): 275-302.

Finchelstein, D. 2017. The role of the State in the internationalization of Latin American firms. Journal of World Business, 52(4): 578-590.

Fisch, J. H. 2008. Investment in new foreign subsidiaries under receding perception of uncertainty. Journal of International Business Studies, 39(3): 370-386.

Fisch, J. H., \& Zschoche, M. 2012. The role of operational flexibility in the expansion of international production networks. Strategic Management Journal, 33(13): 1540-1556.

Flowers E. B. 1976. Oligopolistic reaction in European and Canadian direct investment in the U.S. Journal of International Business Studies, 7(2): 43-55.

Folta, T. B. 1998. Governance and uncertainty: The trade-off between administrative control and commitment. Strategic Management Journal, 19(11): 1007-1028.

Forte, R. P. 2015. Multinational firms and host country market structure: A review of empirical literature. Journal of International Trade \& Economic Development, 25(2): 240-265,

Foss, N. J., Klein, P. G., Kor, Y. Y., \& Mahoney, J. T. 2008. Entrepreneurship, subjectivism, and the resourcebased view: toward a new synthesis. Strategic Entrepreneurship Journal, 2(1): 73-94.

Gaba, V., Pan, Y., \& Ungson, G. R. 2002. Timing of entry in international market: An empirical study of US Fortune 500 firms in China. Journal of International Business Studies, 33(1): 39-55.

Gao, G. Y., \& Pan, Y. 2010. The pace of MNEs' sequential entries: Cumulative entry experience and the dynamic process. Journal of International Business Studies, 41(9): 1572-1580.

Gaur, A. S., \& Lu, J. W. 2007. Ownership strategies and survival of foreign subsidiaries: Impacts of institutional distance and experience. Journal of Management, 33(1): 84-110.

Gaur, A.S., Kumar, V., \& Singh, D. 2014. Institutions, resources, and internationalization of emerging economy firms. Journal of World Business, 49(1): 12-20.

Gaur, A. S., Ma, X., \& Ding, Z. 2018. Home country supportiveness/unfavorableness and outward foreign direct investment from China. Journal of International Business Studies, 49(3): 324-345.

Gaur, A. S., Pattnaik, C., Singh, D., \& Lee, J. Y. 2019. Internalization advantage and subsidiary performance: The role of business group affiliation and host country characteristics. Journal of International Business Studies, 50(8): 1253-1282.

Getachew, Y. S., \& Beamish, P. W. 2017. Foreign subsidiary exit from Africa: the effects of investment purpose diversity and orientation. Global Strategy Journal, 7(1): 58-82.

Ghemawat, P. 2001. Distance still matters - The hard reality of global expansion. Harvard Business Review, 79(8): $137-47$.

Ghemawat, P. 2007. Managing differences - The central challenge of global strategy. Harvard Business Review, 85(3): 58-68.

Ghoshal, S., \& Bartlett, C. A. 1990. The multinational corporation as an interorganizational network. Academy of Management Review, 15(4): 603-626.

Gibson, C. B., Zellmer-Bruhn, M. E. 2001. Metaphors and meaning: An intercultural analysis of the concept of teamwork. Administrative Science Quarterly, 46(2): 274-303.

Gilbert, B. A., McDougall, P. P., \& Audretsch, D. B. 2006. New venture growth: A review and extension. Journal of Management, 32(6): 926-950. 
Gimeno, J., Hoskisson, R. E., Beal, B. D., \& Wan, W. P. 2005. Explaining the clustering of international expansion moves: A critical test in the US telecommunications industry. Academy of Management Journal, 48(2): 297-319.

Goerzen, A., \& Makino, S. 2007. Multinational corporation internationalization in the service sector: a study of Japanese trading companies. Journal of International Business Studies, 38(7): 1149-1169.

Guillén, M. F. 2002. Structural inertia, imitation, and foreign expansion: South Korean firms and business groups in China, 1987-95. Academy of Management Journal, 45(3): 509-525.

Guillén, M. F. 2003. Experience, imitation, and the sequence of foreign entry: wholly owned and joint-venture manufacturing by South Korean firms and business groups in China, 1987-1995. Journal of International Business Studies, 34(2): 185-198.

Guler, I., \& Guillén, M. F. 2010a. Institutions and the internationalization of US venture capital firms. Journal of International Business Studies, 41(2): 185-205.

Guler, I., \& Guillén, M. F. 2010b. Home country networks and foreign expansion: Evidence from the venture capital industry. Academy of Management Journal, 53(2): 390-410.

Gupta, A., \& Misangyi, V. F. 2018. Follow the leader (or not): The influence of peer CEOs' characteristics on interorganizational imitation. Strategic Management Journal, 39(5): 1437-1472.

Hagen, B., \& Zucchella, A. 2014. Born global or born to run? The long-term growth of born global firms. Management International Review, 54(4): 497-525.

Hashai, N. 2011. Sequencing the expansion of geographic scope and foreign operations by "born global" firms. Journal of International Business Studies, 42(8): 995-1015.

Heidenreich, S., Mohr, A., \& Puck, J. 2015. Political strategies, entrepreneurial overconfidence and foreign direct investment in developing countries. Journal of World Business, 50(4): 793-803.

Helfat, C. E., \& Martin, J.A. 2015. Dynamic managerial capabilities: Review and assessment of managerial impact on strategic change. Journal of Management, 41(5): 1281-1312.

Hendry, C. 1996. Continuities in human resource processes in internationalization and domestic business management. Journal of Management Studies, 33(4): 475-494.

Henisz, W. J., \& Delios, A. 2001. Uncertainty, imitation, and plant location: Japanese multinational corporations, 1990-1996. Administrative Science Quarterly, 46(3): 443-475.

Hennart, J. F. 1982. A Theory of Multinational Enterprise. Ann Arbor, MI: University of Michigan Press.

Hennart, J. F. 1993. Explaining the swollen middle - Why most transactions are a mix of market and hierarchy. Organization Science, 4(4): 529-547.

Hennart, J. F., Majocchi, A., \& Forlani, E. 2019. The myth of the stay-at-home family firm: How familymanaged SMEs can overcome their internationalization limitations. Journal of International Business Studies, 50(5): 758-782.

Hennart, J. F., \& Park, Y. R. 1994. Location, governance, and strategic determinants of Japanese manufacturing investment in the United States. Strategic Management Journal, 15(6): 419-436.

Hernandez, E. 2014. Finding a home away from home: Effects of immigrants on firms' foreign location choice and performance. Administrative Science Quarterly, 59(1): 73-108.

Hitt, M. A., Bierman, L., Uhlenbruck, K., \& Shimizu, K. 2006a. The importance of resources in the internationalization of professional service firms: The good, the bad, and the ugly. Academy of Management Journal, 49(6): 1137-1157.

Hitt, M. A., Tihanyi, L., Miller, T., \& Connelly, B. 2006b. International diversification: Antecedents, outcomes, and moderators. Journal of Management, 32(6): 831-867.

Hoenen, A. K., \& Kostova, T. 2015. Utilizing the broader agency perspective for studying headquarterssubsidiary relations in multinational companies. Journal of International Business Studies, 46(1): 104-113.

Hofstede, G. 1984. Culture's Consequences: International Differences in Work-Related Values (2 ${ }^{\text {nd }}$ ed.). Thousand Oaks, CA: Sage Publications.

Holm, A. E., Decreton, B., Nell, P. C., \& Klopf, P. 2017. The dynamic response process to conflicting institutional demands in MNC subsidiaries: An inductive study in the sub-Saharan African e-commerce sector. Global Strategy Journal, 7(1): 104-124.

Hong, S. J., \& Lee, S.-H. 2015. Reducing cultural uncertainty through experience gained in the domestic market. Journal of World Business, 50(3): 428-438.

Hoskisson R. E., Eden, L, Lau, C. M., \& Wright, M. 2000. Strategy in emerging economies. Academy of Management Journal, 43(3): 249-267.

Hutzschenreuter, T., \& Gröne, F. 2009. Product and geographic scope changes of multinational enterprises in response to international competition. Journal of International Business Studies, 40(7): 1149-1170.

Hutzschenreuter, T., Harhoff, P. 2020. National capital city location and subsidiary portfolio expansion: The negative effect of geographic distance to the capital city at inception on the speed of subsequent investments. Journal of International Business Studies, advance online publication February 28. 
https://doi.org/10.1057/s41267-020-00305-1

Hutzschenreuter, T., Kleindienst, I., Guenther, C., \& Hammes, M. 2016. Speed of internationalization of new business units: the impact of direct and indirect learning. Management International Review, 56(6): 849-878.

Hutzschenreuter, T., \& Matt, T. 2017. MNE internationalization patterns, the roles of knowledge stocks, and the portfolio of MNE subsidiaries. Journal of International Business Studies, 48(9): 1131-1150.

Hutzschenreuter, T., Pedersen, T., \& Volberda, H.W. 2007. The role of path dependency and managerial intentionality: A perspective on international business research. Journal of International Business Studies, 38(7): 1055-1068.

Hutzschenreuter, T., Voll, J. C., \& Verbeke, A. 2011. The impact of added cultural distance and cultural diversity on international expansion patterns: A Penrosean perspective. Journal of Management Studies, 48(2): 305-329.

Hymer, S. H. 1960. The international operations of national firms: A study of direct foreign investment. $\mathrm{PhD}$. Thesis, Massachusetts Institute of Technology.

Hymer, S. H. 1976. International Operations of National Firms. MIT Press.

Ito, K., \& Rose, E.L. 2002. Foreign direct investment location strategies in the tire industry. Journal of International Business Studies, 33(3): 593-602.

Iurkov, V., \& Benito, G. R. 2018. Change in domestic network centrality, uncertainty, and the foreign divestment decisions of firms. Journal of International Business Studies, advance online publication October 11. https://doi.org/10.1057/s41267-018-0194-0

Johanson, M., \& Kalinic, I. 2016. Acceleration and deceleration in the internationalization process of the firm. Management International Review, 56(6): 827-847.

Johanson, J., \& Vahlne, J. E. 1977. The internationalization process of the firm-A model of knowledge development and increasing foreign market commitments. Journal of International Business Studies, 8(1): 23-32.

Johanson, J., \& Vahlne, J. E. 1990. The mechanism of internationalisation. International Marketing Review, 7(4): 11-23.

Johanson, J., \& Vahlne, J. E. 2006. Commitment and opportunity development in the internationalization process: A note on the Uppsala internationalization process model. Management International Review, 46(2): 165-178.

Johanson, J., \& Vahlne, J. 2009. The Uppsala internationalization process model revisited: From liability of foreignness to liability of outsidership. Journal of International Business Studies, 40(9): 1411-1431.

Kafouros, M., \& Aliyev, M. 2016. Institutions and foreign subsidiary growth in transition economies: The role of intangible assets and capabilities. Journal of Management Studies, 53(4): 580-607.

Kalasin, K., Dussauge, P., \& Rivera-Santos, M. 2014. The expansion of emerging economy firms into advanced markets: The influence of intentional path-breaking change. Global Strategy Journal, 4(2): 75-103.

Kang, J., Lee, J. Y., \& Ghauri, P. N. 2017. The interplay of Mahalanobis distance and firm capabilities on MNC subsidiary exits from host countries. Management International Review, 57(3): 379-409.

Kano, L., \& Verbeke, A. 2018. Family firm internationalization: Heritage assets and the impact of bifurcation bias. Global Strategy Journal, 8(1): 158-183.

Kawai, N., \& Chung, C. 2019. Expatriate utilization, subsidiary knowledge creation and performance: The moderating role of subsidiary strategic context. Journal of World Business, 54(1): 24-36.

Kay, N. 1999. Hercules and Penrose. Contributions to Political Economy, 18(1): 67-86.

Kim, Y.-C., Lu, J. W., \& Rhee, M. 2012. Learning from age difference: Interorganizational learning and survival in Japanese foreign subsidiaries. Journal of International Business Studies, 43(8): 719-745.

Kirca, A. H., Hult, G. T. M., Roth, K., Cavusgil, S. T., Perry, M. Z., Akdeniz, M. B., ... \& Miller, J. C. 2011. Firm-specific assets, multinationality, and financial performance: A meta-analytic review and theoretical integration. Academy of Management Journal, 54(1): 47-72.

Knickerbocker, F. T. 1973. Oligopolistic Reaction and the Multinational Enterprise. Cambridge, MA: Harvard University Press.

Kogut, B. 1991. Joint ventures and the option to expand and acquire. Management Science, 37(1): 19-33.

Kogut, B., \& Kulatilaka, N. 1994. Operating flexibility, global manufacturing, and the option value of a multinational network. Management Science, 40(1): 123-139.

Kogut, B., \& Zander, U., 1992. Knowledge of the firm, combinative capabilities, and the replication of technology. Organization Science, 3(3): 383-397.

Kor, Y. Y., \& Mahoney, J. T. 2000. Penrose's resource-based approach: The process and product of research management. Journal of Management Studies, 41(1): 183-191.

Kor, Y. Y., \& Mahoney, J. T. 2004. Edith Penrose's (1959) contributions to the resource-based view of strategic creativity. Journal of Management Studies, 37(1): 109-139.

Kor, Y. Y., Mahoney, J. T., Siemsen, E., \& Tan, D. 2016. Penrose's the theory of the growth of the firm: An exemplar of engaged scholarship. Production and Operations Management, 25(10): 1727-1744.

Kor, Y. Y., Mahoney, J., \& Tan, D. 2020. Edith Penrose's under-explored insights in strategic management and international business research. Strategic Management Review. https://doi.org/10.17863/CAM.47991 
Kor, Y. Y., \& Mesko, A. 2013. Dynamic managerial capabilities: Configuration and orchestration of the top executives' capabilities and the firm's dominant logic. Strategic Management Journal, 34(2): 233-244.

Kostova, T., \& Roth, K. 2003. Social capital in multinational corporations and a micro-macro model of its formation. Academy of Management Review, 28(2): 297-317.

Kotha, S., Rindova, V. P., \& Rothaermel, F. T. 2001. Assets and actions: Firm-specific factors in the internationalization of US Internet firms. Journal of International Business Studies, 32(4): 769-791.

Kuemmerle, W. 1997. Building effective R\&D capabilities abroad. Harvard Business Review, 75(2): 61-72.

Kumar, M. S. 2009. The relationship between product and international diversification: The effects of short-run constraints and endogeneity. Strategic Management Journal, 30(1): 99-116.

Kumar, V., Gaur, A. S., \& Pattnaik, C. 2012. Product diversification and international expansion of business groups. Management International Review, 52(2): 175-192.

Kumar, V., Singh, D., Purkayastha, A., Popli, M., \& Gaur, A. 2020. Springboard internationalization by emerging market firms: Speed of first cross-border acquisition. Journal of International Business Studies, 51(2): 172-193.

Landau, C., Karna, A., Richter, A., \& Uhlenbruck, K. 2016. Institutional leverage capability: Creating and using institutional advantages for internationalization. Global Strategy Journal, 6(1): 50-68.

Langley, A., Smallman, C., \& Tsoukas, H. 2013 Process studies of change in organization and management: Unveiling temporality, activity, and flow. Academy of Management Journal, 56(1): 1-13.

Lee, H., Chung, C. C., \& Beamish, P. W. 2019. Configurational characteristics of mandate portfolios and their impact on foreign subsidiary survival. Journal of World Business, online publication January 31. DOI: 10.1016/j.jwb.2019.100999.

Li, H., Yi, X., \& Cui, G. 2017. Emerging market firms' internationalization: How do firms' inward activities affect their outward activities? Strategic Management Journal, 38(13): 2704-2725.

Li, J. 1995. Foreign entry and survival: Effects of strategic choices on performance in international markets. Strategic Management Journal, 16(5): 333-351.

Li, J., Li, Y., \& Shapiro, D. 2012. Knowledge seeking and outward FDI of emerging market firms: The moderating effect of inward FDI. Global Strategy Journal, 2(4): 277-295.

Li, J., Xia, J., Shapiro, D., \& Lin, Z. 2018. Institutional compatibility and the internationalization of Chinese SOEs: The moderating role of home subnational institutions. Journal of World Business, 53(5): 641-652.

Li, J., \& Yue, D. R. 2008. Market size, legal institutions, and international diversification strategies: implications for the performance of multinational firms. Management International Review, 48(6): 667-688.

Li, L., Li, D., \& Dalgic, T. 2004. Internationalization process of small and medium-sized enterprises: Toward a hybrid model of experiential learning and planning. Management International Review: 44(1): 93-116.

Li, Y., Zhang, Y. A., \& Shi, W. 2019. Navigating geographic and cultural distances in international expansion: The paradoxical roles of firm size, age, and ownership. Strategic Management Journal. Advance online publication October 18. https://doi.org/10.1002/smj.3098

Liao, T. J., \& Yu, C. M. J. 2012. Knowledge transfer, regulatory support, legitimacy, and financial performance: The case of foreign firms investing in China. Journal of World Business, 47(1): 114-122.

Lim, E. 2019. Attainment discrepancy and new geographic market entry: The moderating roles of vertical pay disparity and horizontal pay dispersion. Journal of Management Studies, 56(8): 1605-1629.

Lin, W.-T. 2014. How do managers decide on internationalization processes? The role of organizational slack and performance feedback. Journal of World Business, 49(3): 396-408.

Lindqvist, M. 1991. Infant multinationals: The internationalization of young, technology-based Swedish firms. Doctoral dissertation, Stockholm School of Economics, Institute of International Business.

Lu, J., Liu, X., Wright, M., \& Filatotchev, I. 2014. International experience and FDI location choices of Chinese firms: The moderating effects of home country government support and host country institutions. Journal of International Business Studies, 45(4): 428-449.

Luiz, J., Stringfellow, D., \& Jefthas, A. 2017. Institutional complementarity and substitution as an internationalization strategy: The emergence of an African multinational giant. Global Strategy Journal, 7(1): 83-103.

Luo, Y. 1998. Timing of investment and international expansion performance in China. Journal of International Business Studies, 29(2): 391-407.

Luo, Y. 1999. Time-based experience and international expansion: The case of an emerging economy. Journal of Management Studies, 36(4): 505-534.

Luo, Y. 2000. Dynamic capabilities in international expansion. Journal of World Business, 35(4): 355-378.

Luo, Y. 2001. Toward a cooperative view of MNC-host government relations: Building blocks and performance implications. Journal of International Business Studies, 32(3): 401-419.

Luo, Y., \& Bu, J. 2018. When are emerging market multinationals more risk taking? Global Strategy Journal, 8(4): 635-664.

Luo, Y., \& Tung, R. L. 2007. International expansion of emerging market enterprises: A springboard perspective. 
Journal of International Business Studies, 38(4): 481-498.

Ma, X., \& Delios, A. 2010. Host-country headquarters and an MNE's subsequent within-country diversifications. Journal of International Business Studies, 41(3): 517-525.

Madhok, A., \& Keyhani, M. 2012. Acquisitions as entrepreneurship: Asymmetries, opportunities, and the internationalization of multinationals from emerging economies. Global Strategy Journal, 2(1): 26-40.

Mahoney, J.T. 1995. The management of resources and the resource of management. Journal of Business Research, 33(2): 91-101.

Maitland, E., Rose, E.L., \& Nicholas, S. 2005. How firms grow: Clustering as a dynamic model of internationalization. Journal of International Business Studies, 36(4): 435-451.

Majocchi, A., \& Strange, R. 2012. International diversification. Management International Review, 52(6): 879-900.

Makino, S., Lau, C. M., \& Yeh, R. S. 2002. Asset-exploitation versus asset-seeking: Implications for location choice of foreign direct investment from newly industrialized economies. Journal of International Business Studies, 33(3): 403-421.

Mariotti, S., \& Marzano, R. 2019. Varieties of capitalism and the internationalization of state-owned enterprises. Journal of International Business Studies, 50(5): 669-691.

Mariotti, S., Mosconi, R., \& Piscitello, L. 2019. Location and survival of MNEs' subsidiaries: Agglomeration and heterogeneity of firms. Strategic Management Journal, 40(13): 2242-2270.

Martin, X., \& Salomon, R. 2003. Tacitness, learning, and international expansion: A study of foreign direct investment in a knowledge-intensive industry. Organization Science, 14(3): 297-311.

Martin, X., Swaminathan, A., \& Mitchell, W. 1998. Organizational evolution in the inter-organizational environment: Incentives and constraints on international expansion strategy. Administrative Science Quarterly, 43(3): 566-601.

Mata, J., \& Freitas, E. 2012. Foreignness and exit over the life cycle of firms. Journal of International Business Studies, 43(7): 615-630.

Mauri, A., Song, S., \& de Figueiredo, J. N. 2017. Determinants of corporate international expansion beyond the home region: An empirical examination of US multinational enterprises expansion to Europe and AsiaPacific. Global Strategy Journal, 7(4): 400-426.

Mayer, M. C., Stadler, C., \& Hautz, J. 2015. The relationship between product and international diversification: The role of experience. Strategic Management Journal, 36(10): 1458-1468.

Meyer, K. E. 2006. Globalfocusing: From domestic conglomerates to global specialists. Journal of Management Studies, 43(5): 1109-1144.

Meyer, K. E., Mudambi, R., \& Narula, R. 2011. Multinational enterprises and local contexts: The opportunities and challenges of multiple embeddedness. Journal of Management Studies, 48(2): 235-252.

Meyer, K. E., \& Sinani, E. 2009. When and where does foreign direct investment generate positive spillovers? A meta-analysis. Journal of International Business Studies, 40(7): 1075-1094.

Mohr, A., Batsakis, G., \& Stone, Z. 2018. Explaining the effect of rapid internationalization on horizontal foreign divestment in the retail sector: An extended Penrosean perspective. Journal of International Business Studies, 49(7): 779-808.

Monaghan, S., \& Tippmann, E. 2018. Becoming a multinational enterprise: Using industry recipes to achieve rapid multinationalization. Journal of International Business Studies, 49(4): 473-495.

Mudambi, R., \& Navarra, P. 2004. Is knowledge power? Knowledge flows, subsidiary power and rent-seeking within MNCs. Journal of International Business Studies, 35(5): 385-406.

Musteen, M., Francis, J., \& Datta, D.K. 2010. The influence of international networks on internationalization speed and performance: A study of Czech SMEs. Journal of World Business, 45(3): 197-205.

Nachum, L., \& Song, S. 2011. The MNE as a portfolio: Interdependencies in MNE growth trajectory. Journal of International Business Studies, 42(3): 381-405.

Nadolska, A., \& Barkema, H. G. 2007. Learning to internationalise: the pace and success of foreign acquisitions. Journal of International Business Studies, 38(7): 1170-1186.

Narula, R. 2015. The viability of sustained growth by India's MNEs: India's dual economy and constraints from location assets. Management International Review, 55(2): 191-205.

Nielsen, S. 2010. Top management team internationalization and firm performance. Management International Review, 50(2): 185-206.

Nohria, N., \& Ghoshal, S. 1994. Differentiated fit and shared values: Alternatives for managing headquarterssubsidiary relations. Strategic Management Journal, 15(6): 491-502.

O'Donnell, S. W. 2000. Managing foreign subsidiaries: agents of headquarters, or an interdependent network? Strategic Management Journal, 21(5): 525-548.

Oetzel, J. M., \& Oh, C. H. 2014. Learning to carry the cat by the tail: Firm experience, disasters, and multinational subsidiary entry and expansion. Organization Science, 25(3): 732-756.

Oh, C. H., \& Oetzel, J. 2011. Multinationals' response to major disasters: How does subsidiary investment vary 
in response to the type of disaster and the quality of country governance? Strategic Management Journal, 32(6): 658-681.

Paul, D. L., \& Wooster, R. B. 2008. Strategic investments by US firms in transition economies. Journal of International Business Studies, 39(2): 249-266.

Pedersen, T., \& Shaver, J.M. 2011. Internationalization revisited: the big step hypothesis. Global Strategy Journal, 1(3): 263-274.

Pek, S., Oh, C. H., \& Rivera, J. 2018. MNC foreign investment and industrial disasters: The moderating role of technological, safety management, and philanthropic capabilities. Strategic Management Journal, 39(2): 502-526.

Penrose, E. T. 1956. Foreign investment and the growth of the firm. Economic Journal, 66(261): 220-235.

Penrose, E. T. 1959/1995. The Theory of the Growth of the Firm. Oxford, UK: Oxford University Press.

Penrose, E. T. 1968. The Large International Firm in Developing Countries: The International Petroleum Industry. London, UK: Allen \& Unwin.

Penrose, E. T. 1973. International patenting and the less developed countries. Economic Journal, 83(331): 768786.

Perkins, S. E. 2014. When does prior experience pay? Institutional experience and the multinational corporation. Administrative Science Quarterly, 59(1): 145-181

Petersen, B., Welch, L. S., \& Liesch, P. W. 2002. The Internet and foreign market expansion by firms. Management International Review, 42(2): 207-221.

Peterson, M. F., Arregle, J. L., \& Martin, X. 2012. Multilevel models in international business research. Journal of International Business Studies, 43(5): 451-457.

Petricevic, O., \& Teece, D. J. 2019. The structural reshaping of globalization: Implications for strategic sectors, profiting from innovation, and the multinational enterprise. Journal of International Business Studies, 50(9): $1487-1512$.

Pettus, M. L., Kor, Y. Y., Mahoney, J. T., \& Michael, S. C. 2018. Sequencing and timing of strategic responses after industry disruption: Evidence from post-deregulation competition in the US railroad industry. Strategic Organization, 16(4): 373-400.

Pitelis, C.N. 2000. A theory of the (growth of the) transnational firm: A Penrosian Perspective. Contributions to Political Economy, 18(1): 3-22.

Pitelis, C.N. 2002. The Growth of the Firm; the Legacy of Edith Penrose. Oxford, UK: Oxford University Press.

Pitelis, C.N. 2004. Edith Penrose and the resource-based view of (international) business strategy. International Business Review, 13(4): 523-532.

Pitelis, C.N. 2009. Edith Penrose's 'The theory of the growth of the firm" fifty years later. Available at SSRN. dx.doi.org/10.2139/ssrn.1477885

Pitelis, C. N., \& Teece, D. J. 2010. Cross-border market co-creation, dynamic capabilities and the entrepreneurial theory of the multinational enterprise. Industrial and Corporate Change, 19(4):1247-1270.

Pitelis, C. N, \& Verbeke, A. 2007. Edith Penrose and the future of the multinational enterprise: New research directions. Management International Review, 47(2): 139-149.

Powell, K.S. 2014. Profitability and speed of foreign market entry. Management International Review, 54(1): 31-45.

Prahalad, C. \& Doz, Y. 1987. The Multinational Mission: Balancing Local Demand and Global Vision. New York: Free Press.

Qian, G., Li, L., \& Rugman, A. M. 2013. Liability of country foreignness and liability of regional foreignness: Their effects on geographic diversification and firm performance. Journal of International Business Studies, 44(6): 635-647.

Qian, L., \& Delios, A. 2008. Internalization and experience: Japanese banks' international expansion, 19801998. Journal of International Business Studies, 39(2): 231-248.

Ray, S., Mondal, A., \& Ramachandran, K. 2018. How does family involvement affect a firm's internationalization? An investigation of Indian family firms. Global Strategy Journal, 8(1): 73-105.

Ren, H., Gray, B., \& Kim, K. 2009. Performance of international joint ventures: What factors really make a difference and how? Journal of Management, 35(3): 805-832.

Rhee, J. H. 2005. The internet era and the international expansion process: the moderating role of absorptive capacity. Management International Review, 45(3): 277-306.

Rhee, J. H., \& Cheng, J. L. 2002. Foreign market uncertainty and incremental international expansion: The moderating effect of firm, industry, and host country factors. Management International Review, 42 (4): 419-439.

Riaz, S., Rowe, W. G., \& Beamish, P. W. 2014. Expatriate-deployment levels and subsidiary growth: A temporal analysis. Journal of World Business, 49(1): 1-11.

Roth, K., \& Morrison, A. J. 1990. An empirical analysis of the integration-responsiveness framework in global industries. Journal of International Business Studies, 21(4): 541-564. 
Rothaermel, F. T., Kotha, S., \& Steensma, H. K. 2006. International market entry by US Internet firms: An empirical analysis of country risk, national culture, and market size. Journal of Management, 32(1): 56-82.

Rudy, B. C., Miller, S. R., \& Wang, D. 2016. Revisiting FDI strategies and the flow of firm-specific advantages: A focus on state-owned enterprises. Global Strategy Journal, 6(1): 69-78.

Rugman, A. M. 1981. Inside the Multinationals: The Economics of Internal Markets. London, UK: Croom Helm.

Rugman, A. M., \& Verbeke, A. 1992. A note on the transnational solution and the transaction cost theory of multinational strategic management. Journal of International Business Studies, 23(4): 761-771.

Rugman, A. M., \& Verbeke, A. 2001. Subsidiary-specific advantages in multinational enterprises. Strategic Management Journal, 22(3): 237-250.

Rugman, A. M., \& Verbeke, A. 2002. Edith Penrose's contribution to the resource-based view of strategic management. Strategic Management Journal, 23(8): 769-780.

Rugman, A. M., \& Verbeke, A. 2003. Extending the theory of the multinational enterprise: Internalization and strategic management perspectives. Journal of International Business Studies, 34(2): 125-137.

Rugman, A. M., \& Verbeke, A. 2004. A perspective on regional and global strategies of multinational enterprises. Journal of International Business Studies, 35(1): 3-18.

Sambharya, R. B. 1996. Foreign experience of top management teams and international diversification strategies of US multinational corporations. Strategic Management Journal, 17(9): 739-746.

Santangelo, G. D., \& Meyer, K. E. 2017. Internationalization as an evolutionary process. Journal of International Business Studies, 48(9): 1114-1130.

Santangelo, G. D., \& Stucchi, T. 2018. Internationalization through exaptation: The role of domestic geographical dispersion in the internationalization process. Journal of International Business Studies, 49(6): 753-760.

Sarkar, M., Cavusgil, S. T., \& Aulakh, P. S. 1999. International expansion of telecommunication carriers: The influence of market structure, network characteristics, and entry imperfections. Journal of International Business Studies, 30(2): 361-381.

Sartor, M. A., \& Beamish, P. W. 2020. Integration-oriented strategies, host market corruption and the likelihood of foreign subsidiary exit from emerging markets. Journal of International Business Studies, 51(3): 414-431.

Schotter, A., \& Beamish, P. W. 2011. Performance effects of MNC headquarters-subsidiary conflict and the role of boundary spanners: The case of headquarter initiative rejection. Journal of International Management, 17(3): 243-259.

Schu, M., Morschett, D., \& Swoboda, B. 2016. Internationalization speed of online retailers: A resource-based perspective on the influence factors. Management International Review, 56(5): 733-757.

Shapira, Z. 2017. Entering new markets: The effect of performance feedback near aspiration and well below and above it. Strategic Management Journal, 38(7): 1416-1434.

Shaver, J. M., \& Flyer, F. 2000. Agglomeration economies, firm heterogeneity, and foreign direct investment in the United States. Strategic Management Journal, 21(12): 1175-1193.

Shaver, J. M., Mitchell, W., \& Yeung, B. 1997. The effect of own-firm and other-firm experience on foreign direct investment survival in the United States, 1987-92. Strategic Management Journal, 18(10): 811-824.

Shen, T. Y. 1970. Economies of scale, Penrose effect, growth of plants and their size distribution. Journal of Political Economy, 78(4): 702-716.

Shi, W. S., Sun, S. L., Yan, D., \& Zhu, Z. 2017. Institutional fragility and outward foreign direct investment from China. Journal of International Business Studies, 48(4): 452-476.

Simon, H.A. 1947. Administrative Behavior. New York: Macmillan.

Singh, D., \& Delios, A. 2017. Corporate governance, board networks and growth in domestic and international markets: Evidence from India. Journal of World Business, 52(5): 615-627.

Slater, M. 1980. The managerial limitation to the growth of firms. The Economic Journal, 90(359): 520-528.

Song, S. 2014. Subsidiary divestment: The role of multinational flexibility. Management International Review, 54(1): 47-70.

Song, S. 2015. Exchange rate challenges, flexible intra-firm adjustments, and subsidiary longevity. Journal of World Business, 50(1): 36-45.

Song, S., \& Lee, J. Y. 2017. Relationship with headquarters and divestments of foreign subsidiaries: The hysteresis perspective. Management International Review, 57(4): 545-570.

Song, S., Makhija, M., \& Lee, S. 2014. Within-country growth options versus across-country switching options in foreign direct investment. Global Strategy Journal, 4(2): 127-142.

Soule, S.A., Swaminathan, A., \& Tihanyi, L. 2014. The diffusion of foreign divestment from Burma. Strategic Management Journal, 35(7): 1032-1052.

Stallkamp, M., Pinkham, B. C., Schotter, A. P. J., \& Buchel, O. 2018. Core or periphery? The effects of countryof-origin agglomerations on the within-country expansion of MNEs. Journal of International Business 
Studies, 49(8): 942-966.

Steen, J. T., \& Liesch, P. W. 2007. A note on Penrosean growth, resource bundles and the Uppsala model of internationalisation. Management International Review, 47(2): 193-206.

Stoian, M.C., Dimitratos, P., \& Plakoyiannaki, E. 2018. SME internationalization beyond exporting: A knowledge-based perspective across managers and advisers. Journal of World Business, 53(5): 768-779.

Surdu, I., Mellahi, K., \& Glaister, K. W. 2019. Once bitten, not necessarily shy? Determinants of foreign market re-entry commitment strategies. Journal of International Business Studies, 50(3): 393-422.

Surdu, I., Mellahi, K., Glaister, K. W., \& Nardella, G. 2018. Why wait? Organizational learning, institutional quality and the speed of foreign market re-entry after initial entry and exit. Journal of World Business, 53(6): 911-929.

Tan, B., \& Vertinsky, I. 1996. Foreign direct investment by Japanese electronics firms in the United States and Canada: Modelling the timing of entry. Journal of International Business Studies, 27(4): 655-681.

Tan, D. 2009. Foreign market entry strategies and post-entry growth: Acquisitions vs greenfield investments. Journal of International Business Studies, 40(6): 1046-1063.

Tan, D., \& Mahoney, J. T. 2005. Examining the Penrose Effect in an international business context: The dynamics of Japanese firm growth in U.S. industries. Managerial and Decision Economics, 26(2): 113-127.

Tan, D., \& Mahoney, J.T. 2007. The dynamics of Japanese firm growth in US industries: The Penrose effect. Management International Review, 47(2): 259-279.

Tan, D., \& Meyer, K. E. 2011. Country-of-origin and industry FDI agglomeration of foreign investors in an emerging economy. Journal of International Business Studies, 42(4): 504-520.

Tan, Q., \& Sousa, C. M. 2018. Performance and business relatedness as drivers of exit decision: A study of MNCs from an emerging country. Global Strategy Journal, 8(4): 612-634.

Tan, Q., \& Sousa, C. M. 2019. Why poor performance is not enough for a foreign exit: The importance of innovation capability and international experience. Management International Review, 59(3): 465-498.

Teece, D.J. 1977. Technology transfer by multinational firms: The resource cost of transferring technological know-how. Economic Journal, 87(346): 242-261.

Teece, D.J. 1981. The market for know-how and the efficient international transfer of technology. Annals of the American Academy of Political and Social Science, 458(1): 81-96.

Teece, D.J. 1982. Towards an economic theory of the multiproduct firm. Journal of Economic Behavior and Organization, 3(1): 39-63.

Teece, D.J. 2007. Explicating dynamic capabilities: the nature and microfoundations of (sustainable) enterprise performance. Strategic Management Journal, 28(13): 1319-1350.

Teece, D. J. 2014. A dynamic capabilities-based entrepreneurial theory of the multinational enterprise. Journal of International Business Studies, 45(1): 8-37.

Teece, D.J., Pisano, G., \& Shuen, A. 1997. Dynamic capabilities and strategic management. Strategic Management Journal, 18(7): 509-533.

Teece, D.J., Rumelt, R., Dosi, G., \& Winter, D. 1994. Understanding corporate coherence: Theory and evidence. Journal of Economic Behavior and Organization, 23(1): 1-30.

Terjesen, S., Hessels, J., \& Li, D. 2016. Comparative international entrepreneurship: A review and research agenda. Journal of Management, 42(1): 299-344.

Tihanyi, L., Ellstrand, A. E., Daily, C. M., \& Dalton, D. R. 2000. Composition of the top management team and firm international diversification. Journal of Management, 26(6): 1157-1177.

Tihanyi, L., Griffith, D. A., \& Russell, C. J. 2005. The effect of cultural distance on entry mode choice, international diversification, and MNE performance: A meta-analysis. Journal of International Business Studies, 36(3): 270-283.

Tihanyi, L., Hoskisson, R. E., Johnson, R. A., \& Wan, W. P. 2009. Technological competence and international diversification. Management International Review, 49(4): 409-431.

Tihanyi, L., Johnson, R. A., Hoskisson, R. E., \& Hitt, M. A. 2003. Institutional ownership differences and international diversification: The effects of boards of directors and technological opportunity. Academy of Management Journal, 46(2): 195-211.

Tsang, E. W. K. 2020. Family firms and internationalization: An organizational learning perspective. Asia Pacific Journal of Management, 37(1): 205-225.

Tsang, E. W. K., \& Yip, P. S. L. 2007. Economic distance and the survival of foreign direct investments. Academy of Management Journal, 50(5): 1156-1168.

Tsao, S. M., \& Lien, W. H. 2013. Family management and internationalization: The impact on firm performance and innovation. Management International Review, 53(2): 189-213.

Tschoegl, A.E. 2002. FDI and internationalization: evidence from US subsidiaries of foreign banks. Journal of International Business Studies, 33(4): 805-815.

Tseng, C. H., Tansuhaj, P., Hallagan, W., \& McCullough, J. 2007. Effects of firm resources on growth in 
multinationality. Journal of International Business Studies, 38(6): 961-974.

Vahlne, J. E. \& Johanson, J. 2017. From internationalization to evolution: The Uppsala model at 40 years. Journal of International Business Studies, 48(9): 1087-1102.

Vahlne, J. E., \& Ivarsson, I. 2014. The globalization of Swedish MNEs: Empirical evidence and theoretical explanations. Journal of International Business Studies, 45(3): 227-247.

Van Den Bulcke, D., Zhang, H., \& Li, X. 1999. Interaction between the business environment and the corporate strategic positioning of firms in the pharmaceutical industry: A study of the entry and expansion path of MNEs into China. Management International Review, 39(4): 353-377.

Verbeke, A., \& Yuan, W. 2005. Subsidiary autonomous activities in multinational enterprises: A transaction cost perspective. Management International Review, 45(2): 31-52.

Verbeke, A. \& Yuan, W. 2007. Entrepreneurship in multinational enterprises: A Penrosean perspective. Management International Review, 47(2): 241-258.

Vidal, E., \& Mitchell, W. 2018. Virtuous or vicious cycles? The role of divestitures as a complementary Penrose effect within resource-based theory. Strategic Management Journal, 39(1): 131-154.

Wan, W. P., Chen, H. S., \& Yiu, D. W. 2015. Organizational image, identity, and international divestment: A theoretical examination. Global Strategy Journal, 5(3): 205-222.

Wang, S. L., Luo, Y., Lu, X., Sun, J., \& Maksimov, V. 2014. Autonomy delegation to foreign subsidiaries: An enabling mechanism for emerging-market multinationals. Journal of International Business Studies, 45(2): $111-130$.

Xia, J., Ma, X., Tong, T. W., \& Li, W. 2018. Network information and cross-border M\&A activities. Global Strategy Journal, 8(2): 301-323.

Xu, D., \& Shenkar, O. 2002. Institutional distance and the multinational enterprise. Academy of Management Review, 27(4): 608-618.

Young, S., Huang, C. H., \& McDermott, M. 1996. Internationalization and competitive catch-up processes: Case study evidence on Chinese multinational enterprises. Management International Review, 36(4): 295314.

Yu, J, \& Ito, K. 1988. Oligopolistic reaction and foreign direct investment: the case of the U.S. tire and textile industries. Journal of International Business Studies, 19(3): 449-460.

Yuan, L., Qian, X., \& Pangarkar, N. 2016. Market timing and internationalization decisions: A contingency perspective. Journal of Management Studies, 53(4): 497-519.

Zaheer, S. 1995. Overcoming the liability of foreignness. Academy of Management Journal, 38(2): 341-363.

Zaheer, S., \& Mosakowski, E. 1997. The dynamics of the liability of foreignness: A global study of survival in financial services. Strategic Management Journal, 18(6): 439-463.

Zahra, S.A., Ireland, R. D., \& Hitt, M. A. 2000. International expansion by new venture firms: International diversity, mode of market entry, technological learning, and performance. Academy of Management Journal, 43(5): 925-950.

Zellmer-Bruhn, M., \& Gibson, C. 2006. Multinational organization context: Implications for team learning and performance. Academy of Management Journal, 49(3): 501-518.

Zeng, Y., Shenkar, O., Lee, S.H., \& Song, S. 2013a. Cultural differences, MNE learning abilities, and the effect of experience on subsidiary mortality in a dissimilar culture: Evidence from Korean MNEs. Journal of International Business Studies, 44(1): 42-65.

Zeng, Y.P., Shenkar, O., Song, S., \& Lee, S.H. 2013b. FDI experience location and subsidiary mortality. Management International Review, 53(3): 477-509.

Zhong, W., Lin, Y., Gao, D., \& Yang, H. 2019. Does politician turnover affect foreign subsidiary performance? Evidence in China. Journal of International Business Studies, 50(7): 1184-1212.

Zhou, N., \& Guillén, M. F. 2015. From home country to home base: A dynamic approach to the liability of foreignness. Strategic Management Journal, 36(6): 907-917.

Zhu, D. H., \& Chen, G. 2015. CEO narcissism and the impact of prior board experience on corporate strategy. Administrative Science Quarterly, 60(1): 31-65.

Zupic, I., \& Drnovsek, M. 2014. Firm growth: Research front and intellectual structure. In the Academy of Management Proceedings (Vol. 2014, No. 1, p.12367). 
Figure 1a. Proportion of Sample Articles by Topics

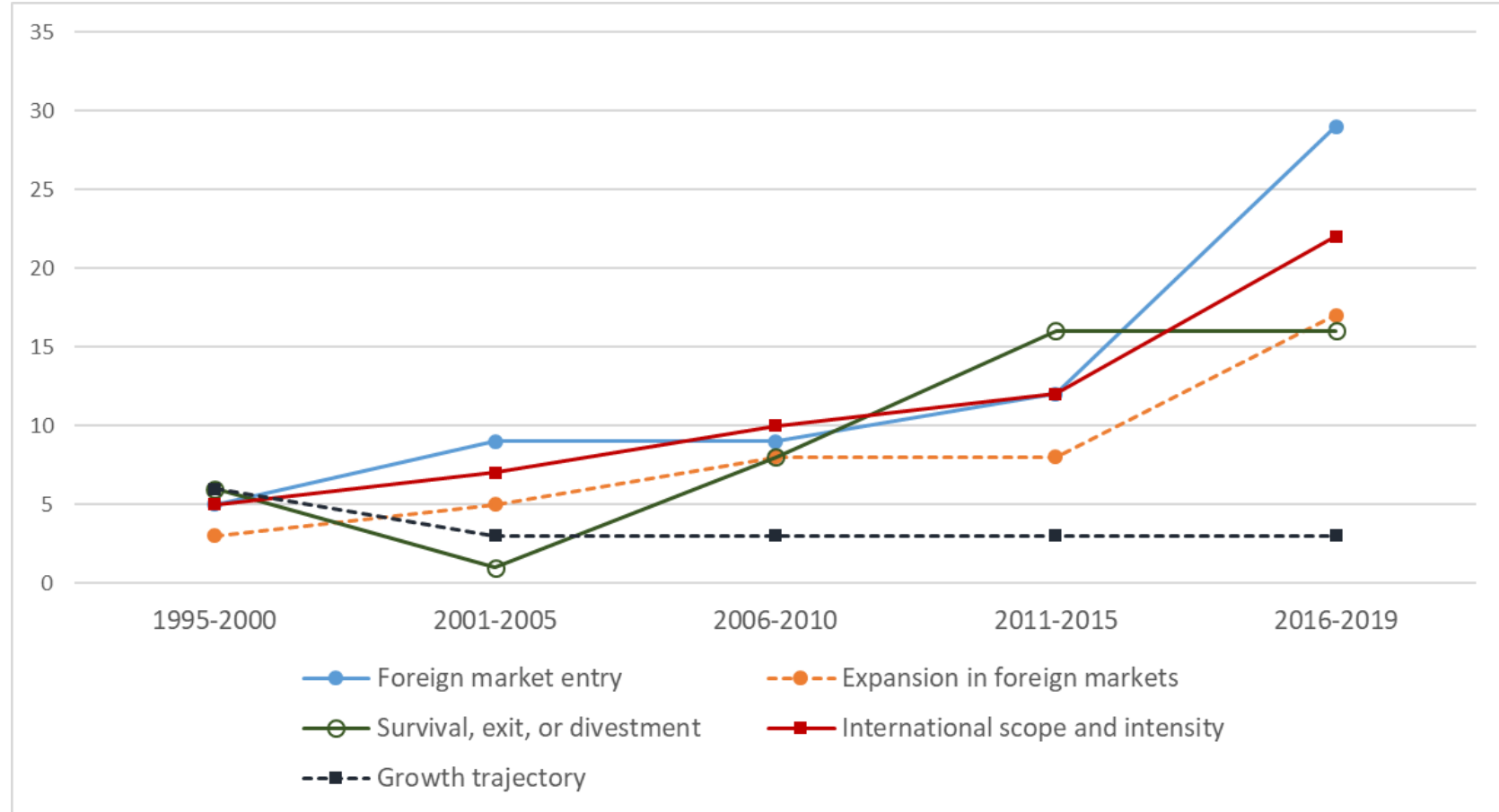

Note: The sum of all of the percentages is greater than $100 \%$ because some articles were classified under two or more topics. The percentage of articles in 2016-2019 includes six articles that were accepted in 2018, 2019, or early 2020 but not in print as of March 2020.

Figure 1b. Numbers of Articles in the Review That Cite Penrose (1959) by Topics

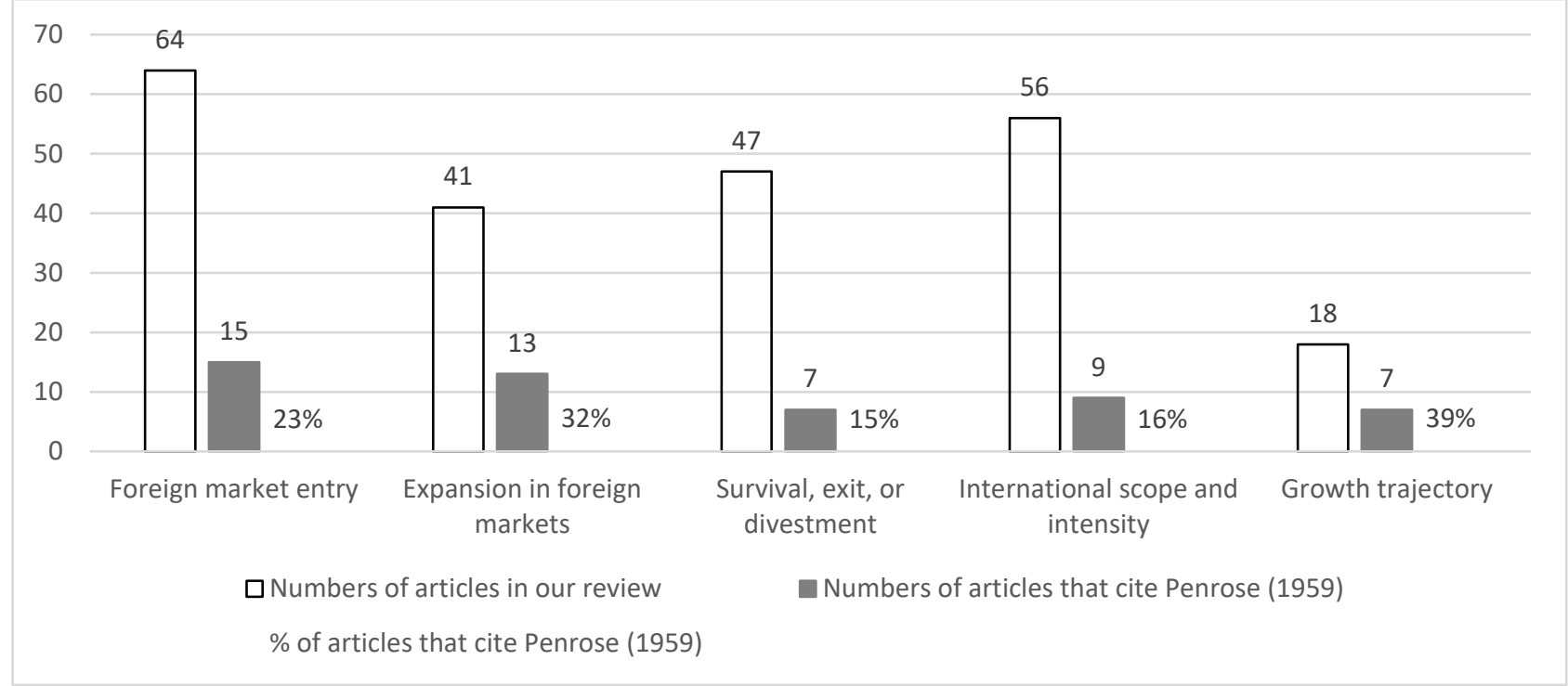

Note: Some articles were classified under two or more topics. Percentages are calculated as the numbers of articles that cite Penrose divided by the total numbers of articles in each of the specific topics on growth. 
Figure 2. Conceptual Diagram for the Underpinning Determinants of the Growth of MNEs

* indicates concepts that are drawn from or corroborate with the Penrosean lens

\section{Moderators for facilitators (examples)}

- Barriers to the transfer of firm-specific resources and experiential knowledge, such as

knowledge tacitness, location boundedness, and environmental dissimilarities*

- Potential of firm-specific resources in adapting to changing environments

- Conditions that affect the importance/usefulness of learning (e.g. composition of experience, availability of foreign market knowledge from other sources)

\begin{tabular}{|c|}
\hline Facilitators \\
\hline $\begin{array}{l}\text { Internal } \\
\text { - Firm-specific resources* } \\
\text { - Managerial resources* } \\
\text { - Experiential learning* }\end{array}$ \\
\hline $\begin{array}{l}\text { External } \\
\text { - Country-level } \\
\text { - Improved host-country conditions } \\
\text { - Support from home governments } \\
\text { - Attempt to escape unfavorable home } \\
\text { country conditions } \\
\text { - Industry-level } \\
\text { - competitive and cooperative conditions }\end{array}$ \\
\hline
\end{tabular}

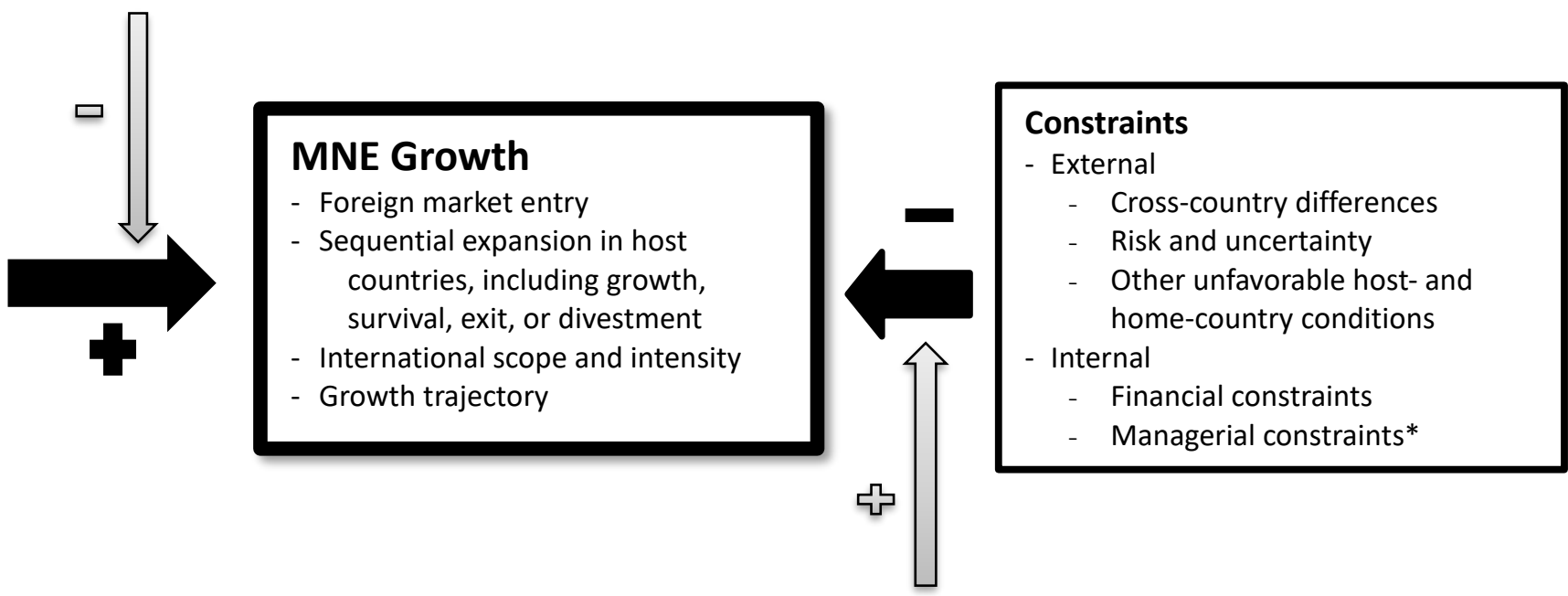

\section{Moderators for external constraints}

- Mechanisms that facilitate access to foreign market knowledge, such as experiential learning and managerial networking

- Firm-specific resources and strategies that offset hostile country conditions and risk, such as superior resources, operational flexibility and non-market strategies

\section{Moderators for internal constraints}

- Financial management that relieves financial constraints

- Firm characteristics (resources, structures or strategies) that economize managerial resources* Firm or external environmental characteristics that facilitate managerial learning* 
Table 1. Facilitators Examined in MNE Growth Research 1995-2019

\begin{tabular}{|c|c|c|}
\hline $\begin{array}{l}\text { Types of } \\
\text { facilitators }\end{array}$ & Variety of facilitators & Conditions theorized or found to influence the impact of facilitators \\
\hline $\begin{array}{l}\text { Firm- } \\
\text { specific } \\
\text { resources }\end{array}$ & $\begin{aligned} \text { - } & \text { Technological and marketing knowledge (Buckley \& Casson, 2007; Chang, 1995; } \\
& \text { Delios \& Beamish, 1999; Gaur et al., 2014; Kirca et al., 2011; Martin \& Salomon, } \\
& \text { 2003; Tan \& Vertinsky, 1996; Tseng et al., 2007) } \\
\text { - } & \text { Intangible assets (Kafouros \& Aliyev, 2016; Kotha, Rindova, \& Rothaermel, 2001) } \\
\text { - } & \text { Innovation (Buckley \& Casson, 2007) } \\
\text { - } & \text { Management infrastructure (Pedersen \& Shaver, 2011) } \\
\text { - } & \text { Capacity to leverage home-country institutions (Landau et al., 2016) } \\
\text { - } & \text { Subsidiary-level mandate portfolios (Lee et al., 2019) }\end{aligned}$ & $\begin{array}{l}\text { Knowledge tacitness and location boundedness weaken the impact (Martin \& } \\
\text { Salomon, 2003; Mauri et al., 2017; Rugman \& Verbeke, 2004). } \\
\text { Adaptability to changing environments affects long-term growth potential (Pitelis \& } \\
\text { Teece, 2010; Teece, 2007, 2014; Vahlne \& Ivarsson, 2014). }\end{array}$ \\
\hline $\begin{array}{l}\text { Managerial } \\
\text { resources }\end{array}$ & $\begin{array}{l}\text { - Managers' international and industry experience and education (Athanassiou \& } \\
\text { Nigh, 2002; Carpenter \& Fredrickson, 2001; Chen et al., 2017; Nielsen, 2010; } \\
\text { Sambharya, 1996; Tihanyi et al. 2000) } \\
\text { - Network connections (Bai et al., 2019; Hagen \& Zucchella, 2014; Johanson \& } \\
\text { Vahlne, 2006, 2009; Luo, 2001; Stallkamp et al., 2018; Stoian et al., 2018) } \\
\text { - Composition of management team (Sambharya, 1996; Barkema \& Shvyrkov, 2007; } \\
\text { Carpenter \& Fredrickson, 2001; Majocchi \& Strange, 2012; Tihanyi et al., 2000) } \\
\text { - Use of expatriate managers (Kawai \& Chung, 2019; Riaz et al., 2014; Tan \& } \\
\text { Mahoney, 2007) } \\
\text { - } \text { Managerial incentives to engage in international expansion (Agnihotri \& } \\
\text { Bhattacharya, 2019; Dow et al., 2018) }\end{array}$ & $\begin{array}{l}\text { Imprinting and constraining effects of experience and connections weaken the impact } \\
\text { (Bingham \& Davis, 2012; Fernández-Méndez et al., 2018; Musteen et al., 2010). } \\
\text { Corporate governance practices or institutional settings affect managerial motivation } \\
\text { (Chittor et al., 2019; Dagnino et al., 2019; Estrin et al., 2016; Lin, 2014; Mariotti \& } \\
\text { Marzano, 2019; Rudy et al., 2016; Singh \& Delios, 2017; Tihanyi et al., 2000; } \\
\text { Tihanyi et al., 2003; Tihanyi et al., 2009). } \\
\text { Synergistic effect exists between managerial experience and connections (Hitt et al., } \\
\text { 2006a). }\end{array}$ \\
\hline $\begin{array}{l}\text { Experiential } \\
\text { learning }\end{array}$ & $\begin{array}{l}\text { Direct experience } \\
-\quad \text { Own experience in foreign operations, including general international } \\
\text { experience and host-country experience (Delios \& Beamish, 2001; Gaur et al., } \\
\text { 2014; Gaur \& Lu, 2007; Hutzschenreuter et al., 2016; Li, 1995; Lu et al. 2014; Luo, } \\
\text { 1999; Nachum \& Song, 2011; Perkins, 2014; Surdu et al., 2018, 2019) } \\
\text { - } \quad \text { Own experience at home (Martin \& Salomon, 2003; Luo \& Bu, 2018; Nadolska } \\
\quad \text { \& Barkema, 2007; Santangelo \& Stucchi, 2018) } \\
\text { Indirect experience } \\
\text { - } \quad \text { From outside of MNE, including foreign alliance partners, interlocking partners, } \\
\text { inward international activities at home, using shared industry recipe, learning from } \\
\text { other firms in the same market (Cesinger et al., 2016; Henisz \& Delios, 2001; Hong } \\
\text { \& Lee, 2015; Hernandez, 2014; Li et al., 2012; Li et al., 2017; Mariotti et al., 2019; } \\
\text { Monaghan \& Tippmann, 2018; Shaver et al., 1997; Shaver \& Flyer, 2000; Xia et al., } \\
\text { 2018) }\end{array}$ & $\begin{array}{l}\text { Transferability (Barkema et al., 1996) and geographical makeup (depth and breadth) } \\
\text { of a firm's international experience (Casillas \& Moreno-Menendez, 2014; Perkins, } \\
\text { 2014; Schu et al., 2016; Zahra et al., 2000; Zhou \& Guillén, 2015) affect the impact of } \\
\text { experience. } \\
\text { Direct and indirect experience are substitutes but can be synergistic (Cui et al., 2015; } \\
\text { Henisz \& Delios, 2001; Hutzschenreuter et al., 2016; Gupta \& Misangyi, 2018; Kim et } \\
\text { al., 2012). } \\
\text { Managerial characteristics influence the tendency of managers relying on direct vs. } \\
\text { indirect learning (Zhu \& Chen, 2015). } \\
\text { External conditions such as the development of Internet influence the speed of } \\
\text { experiential learning (Petersen et al., 2002; Rhee, 2005). }\end{array}$ \\
\hline
\end{tabular}




\begin{tabular}{|c|c|c|}
\hline & $\begin{array}{l}\text { - From MNE/group inside (intra-MNE network) (Banerji \& Sambharya, 1996; } \\
\text { Eriksson et al., 1997; Gaur et al., 2014; Gaur \& Lu, 2007; Guillén, 2003; Kim et al., } \\
\text { 2012) }\end{array}$ & \\
\hline $\begin{array}{l}\text { External } \\
\text { drivers }\end{array}$ & $\begin{array}{l}\text { Country-level } \\
\text { - Improved host-country conditions (Belderbos \& Zou, 2007; Dau, 2012; Dunning \& } \\
\text { Kundu, 1995; Guler \& Guillén, 2010a; Liao \& Yu, 2012; Mauri et al., 2017; Paul \& } \\
\text { Wooster, 2008; Surdu et al., 2019; Tschoegl, 2002; Van Den Bulcke et al., 1999) } \\
\text { - Support from home governments (Finchelstein, 2017; Gaur et al., 2018) } \\
\text { - Attempt to escape unfavorable home-country conditions (Bertrand et al., 2019; } \\
\text { Fathallah et al., 2018; Gaur et al., 2018; Kalasin et al., 2014; Kumar et al., 2020; Li \& } \\
\text { Yue, 2008; Luo \& Tung, 2007; Madhok \& Keyhani, 2012; Shi et al. 2017; Young et al., } \\
\text { 1996) } \\
\text { Industry-level } \\
\text { - Competitive and cooperative conditions (Chang \& Rosenzweig, 1998; Chan et al., } \\
\text { 2006; Gimeno et al., 2005; Guillén, 2002; Guler \& Guillén, 2010b; } \\
\text { Hutzschenreuter \& Gröne, 2009; Ito \& Rose, 2002; Kotha et al., 2001; Li et al., } \\
\text { 2018; Luo, 1998; Martin et al., 1998) }\end{array}$ & $\begin{array}{l}\text { Inward FDI activities at home reduce the need to escape from unfavorable home- } \\
\text { country conditions (Li et al., 2012; Li et al., 2017). } \\
\text { International experience affects the impact of country-level and industry-level } \\
\text { conditions on growth (Gaur et al., 2018; Gupta \& Misangyi, 2018; Qian \& Delios, } \\
\text { 2008; Shi et al., 2017). } \\
\text { Competition in foreign markets reduces the tendency of MNEs to follow } \\
\text { competitors' moves into foreign markets (Chan et al., 2006; Martin et al., 1998). }\end{array}$ \\
\hline
\end{tabular}


Table 2. Constraints Examined in MNE Growth Research 1995-2019

\begin{tabular}{|c|c|c|}
\hline $\begin{array}{l}\text { Types of } \\
\text { constraints }\end{array}$ & Variety of constraints & Conditions theorized or found to influence the impact of constraints \\
\hline $\begin{array}{l}\text { Cross-country } \\
\text { differences }\end{array}$ & $\begin{array}{l}\text { - Differences in cultures, institutional conditions, economic development, and } \\
\text { geographic locations (Barkema et al., 1996; Berry et al., 2010; Beugelsdijk et al., } \\
\text { 2018; Cuervo-Cazurra et al., 2007; Demirbag et al., 2011; Hutzschenreuter et al., } \\
\text { 2011; Kang et al., 2017; Mata \& Freitas, 2012; Qian et al., 2013; Schu et al., 2016; } \\
\text { Tsang \& Yip, 2007; Tihanyi et al., 2005; Xu \& Shenkar, 2002; Zaheer \& } \\
\text { Mosakowski, 1997; Zeng et al., 2013a, 2013b; Zhou \& Guillén, 2015) }\end{array}$ & $\begin{array}{l}\text { Ownership advantages (Kang et al., 2017; Xu \& Shenkar, 2002), firm size and age } \\
\text { (Li et al., 2019), and host-country and international experience (Berry et al., 2010; } \\
\text { Zeng et al., 2013a, 2013b) affect the impact of the differences. } \\
\text { Cross-country differences provide opportunities for arbitrage (Arregle et al., 2016; } \\
\text { Nachum \& Song, 2011; Tsang \& Yip, 2007). }\end{array}$ \\
\hline $\begin{array}{l}\text { Risk and } \\
\text { Uncertainty in } \\
\text { host countries }\end{array}$ & $\begin{array}{l}\text { - General host-country uncertainty (Delios \& Henisz, 2003a; Gaba et al., 2002; Rhee } \\
\text { \& Cheng, 2002) } \\
\text { - Exogenous uncertainty in the form of political hazard, institutional weakness, } \\
\text { exchange rate and labor cost fluctuation, economic crisis, and discontinuous shocks, } \\
\text { such as war, terrorist attacks, natural disasters, as well as technological shutdowns } \\
\text { (Belderbos \& Zou, 2007, 2009; Chung et al., 2010, 2013; Dai et al., 2013, 2017; } \\
\text { Dhanaraj \& Beamish, 2009; Fernández-Méndez et al., 2019; Fisch \& Zschoche, 2012; } \\
\text { Getachew \& Beamish, 2017; Henisz \& Delios, 2001; Oetzel \& Oh, 2014; Oh \& Oetzel, } \\
\text { 2011; Pek et al., 2018; Sartor \& Beamish, 2020; Song, 2014, 2015; Zhong et al., 2019) }\end{array}$ & $\begin{array}{l}\text { The following firm characteristics and strategies weaken the impact of uncertainty } \\
\text { - } \text { Superior resources (Gaba et al., 2002; Pek et al., 2018; Rhee \& Cheng, 2002; Sartor } \\
\text { \& Beamish, 2020) } \\
\text { - } \text { Experience (Buckley et al., 2000; Cuervo-Cazurra \& Genc, 2008; Dai et al., } \\
\text { 2017; Delios \& Henisz, 2003b; Dowell \& Killaly, 2009; Luiz et al., 2017; Oetzel } \\
\quad \text { \& Oh, 2014) } \\
\text { - Operating flexibility (Belderbos \& Zou, 2007; Chung et al., 2010, 2013; Gaur et } \\
\text { al., 2019; Luiz et al., 2017; Song, 2014, 2015; Song \& Lee, 2017) } \\
\text { - Non-market strategies (Heidenreich et al., 2015; Ma \& Delios, 2010; Pek et al., } \\
\text { 2018) } \\
\text { - Managerial networking (Albino-Pimentel et al., 2018; Chen et al., 2018; Dai et al., } \\
\text { 2013) }\end{array}$ \\
\hline $\begin{array}{l}\text { Other host \& } \\
\text { home country } \\
\text { conditions }\end{array}$ & $\begin{array}{l}\text { - Certain host-country cultural dimensions (Rothaermel et al., 2006) } \\
\text { - Adverse home conditions (Narula, 2015; Soule et al., 2014) }\end{array}$ & \\
\hline $\begin{array}{l}\text { Financial } \\
\text { constraints }\end{array}$ & $\begin{array}{l}\text { - Insufficient financial resources (Dagnino et al., 2019; Powell, 2014) } \\
\text { - Unsatisfactory financial performance (Chang, 1996; Lim, 2019; Ref \& Shapira, } \\
\text { 2017; Tan \& Sousa, 2018, 2019) }\end{array}$ & $\begin{array}{l}\text { Financial management (such as strategic utilization of over valuation) relieves } \\
\text { financial constraints (Yuan et al., 2016). } \\
\text { Host-country potential (Berry, 2013) and a strong organizational image (Wan et al., } \\
\text { 2015) delay divestment decisions. }\end{array}$ \\
\hline $\begin{array}{l}\text { Managerial } \\
\text { constraints }\end{array}$ & $\begin{array}{l}\text { - Managerial constraints from fast growth (i.e., Penrose effect) (Gao \& Pan, 2010; } \\
\text { Hashai, 2011; Hutzschenreuter et al., 2011; Johanson \& Kalinic, 2016) } \\
\text { - Managerial constraints in family firms (Alessandri et al., 2018; Duran et al., 2017; } \\
\text { Kano \& Verbeke, 2018; Ray et al., 2018) }\end{array}$ & $\begin{array}{l}\text { Conditions that reduce the needs for managerial inputs and speed up managerial } \\
\text { learnings relieve managerial constraints (Hashai, 2011; Mayer et al., 2015; Mohr et } \\
\text { al., 2018; Tan, 2009; Tan \& Mahoney, 2005, 2007). } \\
\text { Family firms are less constrained if they adopt a global niche business model } \\
\text { (Hennart et al., 2019), are run by later generations (Fang et al., 2018) or have certain } \\
\text { corporate governance characteristics (Bhaumik et al., 2010; Kano \& Verbeke, 2018). }\end{array}$ \\
\hline
\end{tabular}




\section{Table 3. Comparison between MNE Growth Research that Draws on Penrose's Growth Theory and Research that Does Not}

\begin{tabular}{|c|c|c|}
\hline & Research that draws on Penrose's growth theory & Research that does not draw on Penrose's growth theory \\
\hline $\begin{array}{l}\text { Underpinning } \\
\text { conceptualization of a } \\
\text { firm }\end{array}$ & $\begin{array}{l}\text { Firm as a collection of productive resources and an } \\
\text { administrative organization in which managers oversee the uses } \\
\text { of firm-specific resources. }\end{array}$ & $\begin{array}{l}\text { Firm as a hierarchy, which relies on managerial authority to allocate } \\
\text { resources, and as a differentiated network, which consists of a group of } \\
\text { geographically dispersed and goal-disparate organizations }\end{array}$ \\
\hline $\begin{array}{l}\text { Facilitators of MNE } \\
\text { growth }\end{array}$ & $\begin{array}{l}\text { Focuses on internal factors that include: } \\
\text { - } \quad \text { Underutilized fungible resources } \\
\text { - } \quad \text { Managers with firm-specific experience } \\
\text { - } \quad \text { Direct learning about the firm and its resources } \\
\text { - } \quad \text { Enterprising management as a necessary condition } \\
\text { Predicts synergic effects between managerial learning and } \\
\text { firm-specific resources } \\
\text { Sees product diversification as a key mechanism of a firm } \\
\text { expanding its resource and capability (technological) base for } \\
\text { further growth }\end{array}$ & $\begin{array}{l}\text { Focuses on both internal and external factors, including: } \\
\text { - } \quad \text { Firm-specific (intangible) resources with special attention to } \\
\text { technological and marketing knowledge } \\
\text { - } \quad \text { Managerial (international) experiences, connections, and } \\
\text { incentives } \\
\text { - } \quad \text { Direct and indirect learning of host-country knowledge } \\
\text { - Favorable host-country conditions } \\
\text { The growth effects of individual facilitators are in general examined } \\
\text { separately. Interactive effects among individual facilitators are discussed on } \\
\text { an ad hoc basis. } \\
\text { Sees international expansion as a key mechanism of MNEs adapting } \\
\text { and acquiring strategic resources for further growth }\end{array}$ \\
\hline $\begin{array}{l}\text { Constraints on MNE } \\
\text { growth }\end{array}$ & $\begin{array}{l}\text { Focuses on internal factors, specifically } \\
\text { - Managerial constraints (from limited availability of } \\
\text { managers with firm-specific experience) } \\
\text { Sees the failure to address external constraints as the lack of } \\
\text { entrepreneurial imagination and vision }\end{array}$ & $\begin{array}{l}\text { Focuses more on external factors, including: } \\
-\quad \text { Cross-country differences } \\
-\quad \text { Risk and uncertainty } \\
\text { Often discusses the firm attributes and strategies that mitigate the } \\
\text { negative impact of the external factors }\end{array}$ \\
\hline $\begin{array}{l}\text { Trajectory of MNE } \\
\text { growth }\end{array}$ & $\begin{array}{l}\text { Predicts alternative periods of fast and stagnant growth. } \\
\text { Views firm growth as the cumulative growth of collective } \\
\text { knowledge }\end{array}$ & $\begin{array}{l}\text { Corroborates the prediction of the Penrose effect } \\
\text { Views international expansion as a capability building process }\end{array}$ \\
\hline
\end{tabular}


Table 4. Some Research Inquiries from Review of Research on MNE Growth

\begin{tabular}{|c|c|}
\hline Topics & Examples of research inquiries \\
\hline $\begin{array}{l}\text { The growth of an MNE in its } \\
\text { entirety }\end{array}$ & $\begin{array}{l}\text { - How can entry into a new market or subsequent growth in a particular foreign market be influenced by the entry, expansion, and } \\
\text { exit decisions of the MNE in other foreign markets? } \\
\text { - How can entry into a new market or subsequent growth in a particular foreign market be shaped by the HQ's resource allocation } \\
\text { decisions and the bundle of competencies MNEs developed in diversified product markets? } \\
\text { - What is the interplay between product diversification and international growth? Under what conditions do these alternative growth } \\
\text { paths support each other rather than compete? } \\
\text { - How do firm-specific resources at the subsidiary level influence the growth of an MNE as a whole? }\end{array}$ \\
\hline $\begin{array}{l}\text { The nature of an MNE as an } \\
\text { administrative organization }\end{array}$ & $\begin{array}{l}\text { - What constitutes the capabilities of the HQ in maintaining effective control and coordination within the multinational network? } \\
\text { - } \quad \text { What is the role of HQ-specific managerial knowledge in MNE growth? } \\
\text { - } \quad \text { How does managerial opportunism (from both HQs and subsidiary managers) influence the growth of MNEs? }\end{array}$ \\
\hline Facilitators of MNE growth & $\begin{array}{l}\text { - } \quad \text { Do the drivers of new market entry also enhance MNE's subsequent growth in a particular market? } \\
\text { - } \quad \text { What determines the long-term growth of MNEs and what constitutes their dynamic capabilities? } \\
\text { What constitutes the entrepreneurial capabilities of MNEs that facilitate continued new foreign market entries? How do the } \\
\text { - } \quad \text { How do various portfolios of managerial experiences (including HQ-specific, host market-specific, and general international experience) } \\
\text { influence the growth of MNEs? } \\
\text { - } \quad \text { How do subsidiary managers influence the post-entry growth and competitiveness of the subsidiary as well as the MNE as a whole? } \\
\text { - } \quad \text { How does the diversity of individual-level and firm-level experience affect the growth of MNEs? } \\
\text { - How can firms avoid the imprinting effect of prior experiential learning? } \\
\text { What are the relationships between direct host-country experience, indirect experience, and firm-specific experience and their } \\
\text { impacts on MNE growth? }\end{array}$ \\
\hline Constraints on MNE growth & $\begin{array}{l}\text { - To what extent can MNEs mitigate seemingly external constraints with organizational designs and strategies? } \\
\text { - Can MNEs use autonomous organizational structures to reduce the need for administrative coordination and thus escape managerial } \\
\text { constraints? } \\
\text { - Should and how do MNEs achieve the balance between preserving their strategic coherence and responding to growth opportunities from } \\
\text { foreign expansion? }\end{array}$ \\
\hline Moderators of MNE growth & - $\quad$ How do managerial characteristics interact with firm-level and environmental characteristics to influence the growth of MNEs? \\
\hline Trajectory of MNE growth & $\begin{array}{l}\text { - Given that the growth of (multinational) firms reflects the cumulative growth of new knowledge, what is the interplay among } \\
\text { innovation, product diversification, and international expansion? } \\
\text { - How do the impacts of individual- and firm-level determinants vary across different stages of growth of MNEs? }\end{array}$ \\
\hline
\end{tabular}


Appendix: A Complete List of Articles Featured in the Sample

\begin{tabular}{|c|c|c|c|}
\hline Author \& Year & Journal & Themes & $\begin{array}{c}\text { Growth } \\
\text { type }\end{array}$ \\
\hline $\begin{array}{l}\text { Agnihotri \& Bhattacharya } \\
(2019)\end{array}$ & MIR & $\mathrm{F}$ & $\mathrm{d}$ \\
\hline $\begin{array}{l}\text { Albino-Pimentel et al. } \\
(2018)\end{array}$ & SMJ & $\mathrm{C}$ & $\mathrm{a}$ \\
\hline Alessandri et al. (2018) & GSJ & $\mathrm{C}$ & $\mathrm{d}$ \\
\hline Arregle et al. (2016) & JIBS & $\mathrm{C}$ & $\mathrm{d}$ \\
\hline $\begin{array}{l}\text { Athanassiou \& Nigh } \\
(2002)\end{array}$ & MIR & $\mathrm{F}$ & $\mathrm{d}$ \\
\hline Bai et al. (2019) & MIR & $\mathrm{F}$ & $\mathrm{d}$ \\
\hline $\begin{array}{l}\text { Banerji \& Sambharya } \\
\text { (1996) }\end{array}$ & JIBS & $\mathrm{F}$ & $\mathrm{a}$ \\
\hline $\begin{array}{l}\text { Barkema \& Shvyrkov } \\
(2007)\end{array}$ & SMJ & $\mathrm{F}$ & a \\
\hline Barkema et al. (1996)† & SMJ & $\mathrm{F}, \mathrm{C}$ & $\mathrm{c}$ \\
\hline Belderbos \& Zou (2007)† & JIBS & $\mathrm{F}, \mathrm{C}$ & $\mathrm{b}, \mathrm{c}$ \\
\hline Belderbos \& Zou (2009) & JIBS & $\mathrm{C}$ & $\mathrm{c}$ \\
\hline Berry (2013) & OS & $\mathrm{C}$ & $\mathrm{c}$ \\
\hline Berry et al. (2010) & JIBS & $\mathrm{C}$ & $\mathrm{a}$ \\
\hline Bertrand et al. (2019) & GSJ & $\mathrm{F}$ & $\mathrm{a}$ \\
\hline Beugelsdijk et al. (2018)† & JOM & $\mathrm{C}$ & $\mathrm{a}$ \\
\hline Bhaumik et al. (2010) & JIBS & $\mathrm{C}$ & $\mathrm{d}$ \\
\hline Bingham \& Davis (2012) & AMJ & $\mathrm{F}$ & $\mathrm{a}, \mathrm{b}$ \\
\hline $\begin{array}{l}\text { Bowen \& Sleuwaegen } \\
(2017) \dagger^{*}\end{array}$ & GSJ & $\mathrm{T}$ & $\mathrm{d}$ \\
\hline $\begin{array}{l}\text { Buckley \& Casson } \\
(2007) \text { t* }^{*}\end{array}$ & MIR & $\mathrm{F}$ & $\mathrm{d}$ \\
\hline Buckley et al. (2020) & JWB & $\mathrm{C}$ & $\mathrm{a}$ \\
\hline $\begin{array}{l}\text { Carpenter \& Fredrickson } \\
(2001)\end{array}$ & AMJ & $\mathrm{F}$ & $\mathrm{d}$ \\
\hline $\begin{array}{l}\text { Casillas \& Moreno- } \\
\text { Menéndez (2014) }\end{array}$ & JIBS & $\mathrm{F}$ & $\mathrm{b}$ \\
\hline Cesinger et al. (2016) & JWB & $\mathrm{F}$ & $\mathrm{d}$ \\
\hline Chan et al. (2006)† & JIBS & $\mathrm{F}$ & $\mathrm{a}, \mathrm{b}$ \\
\hline Chang (1995)† & AMJ & $\mathrm{F}, \mathrm{T}$ & $\mathrm{e}$ \\
\hline Chang (1996) $\dagger$ & SMJ & $\mathrm{C}$ & $\mathrm{a}, \mathrm{c}$ \\
\hline $\begin{array}{l}\text { Chang \& Rosenweig } \\
(1998) \dagger\end{array}$ & JMS & $\mathrm{F}$ & $\mathrm{b}$ \\
\hline Chen (2003) & JMS & $\mathrm{T}$ & $\mathrm{e}$ \\
\hline Chen et al. (2017) & MIR & $\mathrm{F}$ & $\mathrm{d}$ \\
\hline Chen et al. (2018) & GSJ & $\mathrm{C}$ & $\mathrm{a}$ \\
\hline Chittoor et al. (2019) & GSJ & $\mathrm{F}$ & $\mathrm{d}$ \\
\hline Chung et al. (2010) & JIBS & $\mathrm{C}$ & $\mathrm{b}$ \\
\hline Chung et al. (2013) & MIR & $\mathrm{C}$ & $\mathrm{c}$ \\
\hline $\begin{array}{l}\text { Cuervo-Cazurra \& Genc } \\
(2008)\end{array}$ & JIBS & $\mathrm{C}$ & $\mathrm{d}$ \\
\hline $\begin{array}{l}\text { Cuervo-Cazurra et al. } \\
(2007) \dagger\end{array}$ & JIBS & $\mathrm{C}$ & $\mathrm{c}$ \\
\hline Cui et al. (2015) & MIR & $\mathrm{F}$ & $\mathrm{a}$ \\
\hline Dagnino et al. (2019) & GSJ & $\mathrm{F}, \mathrm{C}$ & $\mathrm{d}$ \\
\hline Dai et al. (2013) & JIBS & $\mathrm{C}$ & $\mathrm{c}$ \\
\hline Dai et al. (2017) & SMJ & $\mathrm{C}$ & $\mathrm{c}$ \\
\hline Dau (2012) & GSJ & $\mathrm{F}$ & $\mathrm{d}$ \\
\hline $\begin{array}{l}\text { Delios \& Beamish } \\
(1999) \dagger\end{array}$ & SMJ & $\mathrm{F}$ & $\mathrm{d}$ \\
\hline Delios \& Beamish (2001) & AMJ & $\mathrm{F}$ & $\mathrm{c}$ \\
\hline Delios \& Henisz (2003a) & JIBS & $\mathrm{C}$ & $\mathrm{b}$ \\
\hline Delios \& Henisz (2003b) & SMJ & $\mathrm{C}$ & $\mathrm{a}, \mathrm{b}$ \\
\hline Delios et al. (2008) & JIBS & $\mathrm{T}$ & $\mathrm{c}$ \\
\hline Demirbaga et al. (2011) & JWB & $\mathrm{C}$ & $\mathrm{c}$ \\
\hline $\begin{array}{l}\text { Dhanaraj \& Beamish } \\
(2009)\end{array}$ & MIR & $\mathrm{C}$ & $\mathrm{c}$ \\
\hline Dow et al. $(2018) \dagger$ & MIR & $\mathrm{F}$ & $\mathrm{b}$ \\
\hline Dowell \& Killaly (2009) & OS & $\mathrm{C}$ & $\mathrm{a}$ \\
\hline Dunning \& Kundu (1995) & MIR & $\mathrm{F}$ & $\mathrm{a}$ \\
\hline
\end{tabular}

\begin{tabular}{|c|c|c|c|}
\hline Duran et al. (2017) & JWB & $\mathrm{C}$ & $\mathrm{d}$ \\
\hline Eriksson et al. (1997)† & JIBS & $\mathrm{F}$ & $\mathrm{e}$ \\
\hline Estrin et al. (2016) & JWB & $\mathrm{F}$ & $\mathrm{d}$ \\
\hline Fang et al. (2018) & GSJ & $\mathrm{C}$ & $\mathrm{d}$ \\
\hline Fathallah et al. (2018) & JWB & $\mathrm{F}$ & $\mathrm{a}, \mathrm{b}$ \\
\hline $\begin{array}{l}\text { Fernandez-Mendez et al. } \\
(2018)\end{array}$ & JWB & $\mathrm{F}$ & $\mathrm{a}, \mathrm{b}$ \\
\hline $\begin{array}{l}\text { Fernández-Méndez et al. } \\
(2019)\end{array}$ & GSJ & $\mathrm{C}$ & $\mathrm{c}$ \\
\hline Finchelstein (2017) & JWB & $\mathrm{F}$ & $\mathrm{b}, \mathrm{d}$ \\
\hline Fisch (2008) & JIBS & $\mathrm{T}$ & $\mathrm{b}$ \\
\hline Fisch \& Zschoche (2012) & SMJ & $\mathrm{C}$ & $\mathrm{a}$ \\
\hline Gaba et al. (2002) & JIBS & $\mathrm{C}$ & $\mathrm{a}$ \\
\hline Gao \& Pan (2010) & JIBS & $\mathrm{C}$ & $\mathrm{b}$ \\
\hline Gaur \& Lu (2007) & JOM & $\mathrm{F}$ & $\mathrm{c}$ \\
\hline Gaur et al. (2014) & JWB & $\mathrm{F}$ & $\mathrm{a}$ \\
\hline Gaur et al. (2018) & JIBS & $\mathrm{C}$ & $\mathrm{d}$ \\
\hline Gaur et al. (2019) & JIBS & $\mathrm{C}$ & $\mathrm{c}$ \\
\hline $\begin{array}{l}\text { Getachew \& Beamish } \\
(2017)\end{array}$ & GSJ & $\mathrm{F}$ & $\mathrm{c}$ \\
\hline Gimeno et al. (2005) & AMJ & $\mathrm{T}$ & $\mathrm{a}$ \\
\hline $\begin{array}{l}\text { Goerzen \& Makino } \\
(2007) \dagger\end{array}$ & JIBS & $\mathrm{T}$ & e \\
\hline Guillen (2002) & AMJ & $\mathrm{F}$ & $\mathrm{a}, \mathrm{b}$ \\
\hline Guillen (2003) & JIBS & $\mathrm{F}$ & $\mathrm{b}$ \\
\hline Guler \& Guillen (2010a) $\dagger$ & JIBS & $\mathrm{F}$ & $\mathrm{a}$ \\
\hline Guler \& Guillen (2010b) & AMJ & $\mathrm{F}$ & $\mathrm{a}$ \\
\hline Gupta \& Misangyi (2018) & SMJ & $\mathrm{F}$ & $\mathrm{d}$ \\
\hline $\begin{array}{l}\text { Hagen \& Zucchella } \\
(2014)\end{array}$ & MIR & $\mathrm{F}$ & $\mathrm{e}$ \\
\hline Hashai $(2011) \dagger^{*}$ & JIBS & $\mathrm{C}$ & $\mathrm{b}, \mathrm{d}$ \\
\hline Heidenreich et al. (2015) & JWB & $\mathrm{C}$ & $\mathrm{c}$ \\
\hline Hendry (1996) & JMS & $\mathrm{T}$ & $\mathrm{e}$ \\
\hline Henisz \& Delios (2001) & ASQ & $\mathrm{F}, \mathrm{C}$ & $\mathrm{a}$ \\
\hline Hennart et al. (2019) & JIBS & $\mathrm{C}$ & $\mathrm{d}$ \\
\hline Hernandez (2014) & ASQ & $\mathrm{F}$ & $\mathrm{c}$ \\
\hline Hitt et al. (2006a) & AMJ & $\mathrm{F}$ & $\mathrm{d}$ \\
\hline Hong \& Lee (2015) & JWB & $\mathrm{F}$ & $\mathrm{a}$ \\
\hline $\begin{array}{l}\text { Hutzschenreuter \& Grone } \\
(2009)\end{array}$ & JIBS & $\mathrm{F}$ & $b, d$ \\
\hline $\begin{array}{l}\text { Hutzschenreuter \& } \\
\text { Harhoff }(2020)\end{array}$ & JIBS & $\mathrm{T}$ & $\mathrm{b}$ \\
\hline $\begin{array}{l}\text { Hutzschenreuter et al. } \\
(2011)^{\dagger *}\end{array}$ & JMS & $\mathrm{C}$ & $\mathrm{b}$ \\
\hline $\begin{array}{l}\text { Hutzschenreuter et al. } \\
(2016) \dagger^{* *}\end{array}$ & MIR & $\mathrm{F}$ & $\mathrm{b}$ \\
\hline Ito \& Rose (2002) & JIBS & $\mathrm{F}$ & $\mathrm{a}$ \\
\hline Iurkov \& Benito (2018) & JIBS & $\mathrm{F}$ & $\mathrm{c}$ \\
\hline $\begin{array}{l}\text { Johanson \& Kalinic } \\
(2016)\end{array}$ & MIR & $\mathrm{C}$ & $\mathrm{b}$ \\
\hline $\begin{array}{l}\text { Johanson \& Vahlne } \\
(2006) \dagger\end{array}$ & MIR & $\mathrm{F}$ & $\mathrm{e}$ \\
\hline $\begin{array}{l}\text { Johanson \& Vahlne } \\
(2009) \dagger\end{array}$ & JIBS & $\mathrm{F}$ & e \\
\hline $\begin{array}{l}\text { Kafouros \& Aliyev } \\
(2016) \dagger\end{array}$ & JMS & $\mathrm{F}$ & $\mathrm{b}$ \\
\hline Kalasin et al. (2014) $\dagger$ & GSJ & $\mathrm{F}$ & $\mathrm{a}$ \\
\hline Kang et al. (2017) & MIR & $\mathrm{C}$ & $\mathrm{c}$ \\
\hline Kano \& Verbeke (2018) & GSJ & $\mathrm{C}$ & $\mathrm{e}$ \\
\hline Kawai \& Chung (2019) & JWB & $\mathrm{F}$ & $\mathrm{d}$ \\
\hline Kim et al. $(2012) \dagger^{*}$ & JIBS & $\mathrm{F}$ & $\mathrm{c}$ \\
\hline Kirca et al. (2011) & AMJ & $\mathrm{F}$ & $\mathrm{d}$ \\
\hline Kotha et al. (2001)† & JIBS & $\mathrm{F}$ & $\mathrm{d}$ \\
\hline Kumar $(2009) \dagger^{*}$ & SMJ & $\mathrm{T}$ & $\mathrm{d}$ \\
\hline Kumar et al. (2012) & MIR & $\mathrm{T}$ & $\mathrm{d}$ \\
\hline Kumar et al. (2020) & JIBS & $\mathrm{F}$ & $\mathrm{a}$ \\
\hline
\end{tabular}




\begin{tabular}{|c|c|c|c|}
\hline Landau et al. (2016) & GSJ & $\mathrm{F}$ & $\mathrm{a}$ \\
\hline Lee et al. (2019) & JWB & $\mathrm{F}$ & $\mathrm{c}$ \\
\hline $\mathrm{Li}(1995)$ & SMJ & $\mathrm{F}, \mathrm{T}$ & $\mathrm{c}, \mathrm{e}$ \\
\hline Li \& Yue (2008) & MIR & $\mathrm{F}$ & $\mathrm{d}$ \\
\hline Li et al. (2012) & GSJ & $\mathrm{F}$ & $\mathrm{a}$ \\
\hline Li et al. $(2017) \dagger$ & SMJ & $\mathrm{F}$ & $\mathrm{a}$ \\
\hline Li et al. (2018) & JWB & $\mathrm{F}$ & $\mathrm{a}$ \\
\hline Li et al. (2019) & SMJ & $\mathrm{C}$ & $\mathrm{a}$ \\
\hline Liao \& Yu (2012) & JWB & $\mathrm{F}$ & $\mathrm{b}$ \\
\hline $\operatorname{Lim}(2019)$ & JMS & $\mathrm{C}$ & $\mathrm{a}$ \\
\hline Lin (2014) & JWB & $\mathrm{F}$ & $\mathrm{b}, \mathrm{d}$ \\
\hline Lu et al. (2014) & JIBS & $\mathrm{F}$ & $\mathrm{a}$ \\
\hline Luiz et al. (2017) & GSJ & $\mathrm{C}$ & $\mathrm{e}$ \\
\hline Luo (1998) & JIBS & $\mathrm{F}$ & $\mathrm{d}$ \\
\hline Luo (1999) & JMS & $\mathrm{F}$ & $\mathrm{b}$ \\
\hline Luo (2001) & JIBS & $\mathrm{F}$ & $\mathrm{d}$ \\
\hline Luo \& Bu (2018) & GSJ & $\mathrm{F}$ & $\mathrm{a}, \mathrm{b}$ \\
\hline Luo \& Tung (2007) & JIBS & $\mathrm{F}$ & $\mathrm{a}$ \\
\hline Ma \& Delios (2010) & JIBS & $\mathrm{C}$ & $\mathrm{d}$ \\
\hline $\begin{array}{l}\text { Madhok \& Keyhani } \\
(2012) \dagger\end{array}$ & GSJ & $\mathrm{F}$ & $\mathrm{a}$ \\
\hline Maitland et al. (2005) & JIBS & $\mathrm{T}$ & $\mathrm{e}$ \\
\hline $\begin{array}{l}\text { Majocchi \& Strange } \\
(2012)\end{array}$ & MIR & $\mathrm{F}$ & $\mathrm{d}$ \\
\hline $\begin{array}{l}\text { Mariotti \& Marzano } \\
(2019)\end{array}$ & JIBS & $\mathrm{F}$ & $d$ \\
\hline Mariotti et al. (2019) & SMJ & $\mathrm{F}$ & $\mathrm{a}, \mathrm{c}$ \\
\hline $\begin{array}{l}\text { Martin \& Salomon } \\
(2003) \dagger\end{array}$ & OS & $\mathrm{F}$ & $\mathrm{a}$ \\
\hline Martin et al. (1998) $\dagger$ & ASQ & $\mathrm{F}$ & $\mathrm{a}$ \\
\hline Mata \& Freitas (2012) & JIBS & $\mathrm{C}$ & $\mathrm{c}$ \\
\hline Mauri et al. (2017) & GSJ & $\mathrm{F}$ & $\mathrm{d}$ \\
\hline Mayer et al. (2015) †* & SMJ & $\mathrm{C}, \mathrm{T}$ & $\mathrm{d}$ \\
\hline Mohr et al. (2018)†* & JIBS & $\mathrm{C}$ & $\mathrm{c}$ \\
\hline $\begin{array}{l}\text { Monaghan \& Tippmann } \\
(2018)\end{array}$ & JIBS & $\mathrm{F}$ & $\mathrm{a}$ \\
\hline Musteen et al. (2010) & JWB & $\mathrm{F}$ & $\mathrm{a}$ \\
\hline Nachum \& Song (2011)† & JIBS & $\mathrm{F}, \mathrm{C}, \mathrm{T}$ & $\mathrm{a}, \mathrm{c}$ \\
\hline $\begin{array}{l}\text { Nadolska \& Barkema } \\
(2007)\end{array}$ & JIBS & $\mathrm{F}$ & $\mathrm{b}, \mathrm{c}$ \\
\hline Narula (2015) & MIR & $\mathrm{C}$ & $\mathrm{b}$ \\
\hline Nielsen $(2010) \dagger$ & MIR & $\mathrm{F}$ & $\mathrm{a}$ \\
\hline Oetzel \& Oh (2014) & OS & $\mathrm{C}$ & $\mathrm{c}, \mathrm{d}$ \\
\hline Oh \& Oetzel (2011) & SMJ & $\mathrm{C}$ & $\mathrm{c}, \mathrm{d}$ \\
\hline Paul \& Wooster (2008) & JIBS & $\mathrm{F}$ & $\mathrm{d}$ \\
\hline $\begin{array}{l}\text { Pedersen \& Shaver } \\
(2011) \dagger\end{array}$ & GSJ & $\mathrm{F}, \mathrm{T}$ & $\mathrm{e}$ \\
\hline Pek et al. (2018) & SMJ & $\mathrm{C}$ & $\mathrm{a}, \mathrm{d}$ \\
\hline Perkins (2014) & ASQ & $\mathrm{F}$ & $\mathrm{c}$ \\
\hline Petersen et al. (2002) & MIR & $\mathrm{F}$ & $\mathrm{a}$ \\
\hline Powell (2014) & MIR & $\mathrm{C}$ & $\mathrm{a}$ \\
\hline Qian \& Delios (2008) & JIBS & $\mathrm{F}$ & $\mathrm{a}$ \\
\hline Qian et al. (2013) & JIBS & $\mathrm{C}$ & $\mathrm{d}$ \\
\hline Ray et al. (2018) & GSJ & $\mathrm{C}$ & $\mathrm{d}$ \\
\hline
\end{tabular}

\begin{tabular}{|c|c|c|c|}
\hline Ref \& Shapira (2017) $\dagger$ & SMJ & $\mathrm{C}$ & $\mathrm{a}$ \\
\hline Rhee (2005) & MIR & $\mathrm{F}$ & $\mathrm{e}$ \\
\hline Rhee \& Cheng (2002) & MIR & $\mathrm{C}$ & $\mathrm{b}, \mathrm{d}$ \\
\hline Riaz et al. (2014)†* & JWB & $\mathrm{F}$ & $\mathrm{b}, \mathrm{d}$ \\
\hline Rothaermel et al. (2006) & JOM & $\mathrm{C}$ & $\mathrm{a}$ \\
\hline Rudy et al. (2016) & GSJ & $\mathrm{F}$ & $\mathrm{a}$ \\
\hline Sambharya (1996) & SMJ & $\mathrm{F}$ & $\mathrm{d}$ \\
\hline $\begin{array}{l}\text { Santagelo \& Stucchi } \\
(2018)\end{array}$ & JIBS & $\mathrm{F}$ & $\mathrm{b}$ \\
\hline Sarkar et al. (1999) & JIBS & $\mathrm{T}$ & $\mathrm{b}, \mathrm{d}$ \\
\hline Sartor \& Beamish (2020) & JIBS & $\mathrm{C}$ & $\mathrm{c}$ \\
\hline Schu et al. (2016) $\dagger$ & MIR & $\mathrm{F}, \mathrm{C}$ & $\mathrm{a}, \mathrm{b}$ \\
\hline Shaver \& Flyer (2000) & SMJ & $\mathrm{F}$ & $\mathrm{c}$ \\
\hline Shaver et al. (1997) & SMJ & $\mathrm{F}$ & $\mathrm{c}$ \\
\hline Shi et al. (2017) & JIBS & $\mathrm{F}$ & $\mathrm{a}$ \\
\hline Singh \& Delios (2017)† & JWB & $\mathrm{F}$ & $\mathrm{a}, \mathrm{b}$ \\
\hline Song (2014) & MIR & $\mathrm{C}$ & $\mathrm{c}$ \\
\hline Song (2015) & JWB & $\mathrm{C}$ & $\mathrm{c}$ \\
\hline Song \& Lee (2017) & MIR & $\mathrm{C}$ & $\mathrm{c}$ \\
\hline Soule et al. (2014) & SMJ & $\mathrm{C}$ & $\mathrm{c}$ \\
\hline Stallkamp et al. (2018) & JIBS & $\mathrm{F}$ & $\mathrm{b}$ \\
\hline Stoian et al. (2018) & JWB & $\mathrm{F}$ & $\mathrm{a}$ \\
\hline Surdu et al. (2018) & JWB & $\mathrm{F}$ & $\mathrm{a}$ \\
\hline Surdu et al. (2019) & JIBS & $\mathrm{F}$ & $a, b$ \\
\hline $\operatorname{Tan}(2009) \dagger^{*}$ & JIBS & $\mathrm{C}$ & $\mathrm{b}$ \\
\hline Tan \& Mahoney (2007) †* & MIR & $\mathrm{F}, \mathrm{C}$ & $\mathrm{b}$ \\
\hline Tan \& Sousa (2018) & GSJ & $\mathrm{C}$ & $\mathrm{c}$ \\
\hline Tan \& Sousa (2019) & MIR & $\mathrm{C}$ & $\mathrm{c}$ \\
\hline Tan \& Vertinsky (1996) & JIBS & $\mathrm{F}$ & $\mathrm{a}$ \\
\hline Tihanyi et al. (2000) & JOM & $\mathrm{F}$ & $\mathrm{d}$ \\
\hline Tihanyi et al. (2003) & AMJ & $\mathrm{F}$ & $\mathrm{d}$ \\
\hline Tihanyi et al. (2005) & JIBS & $\mathrm{C}$ & $\mathrm{d}$ \\
\hline Tihanyi et al. (2009) & MIR & $\mathrm{F}$ & $\mathrm{d}$ \\
\hline Tsang \& Yip (2007) & AMJ & $\mathrm{C}$ & $\mathrm{c}$ \\
\hline Tschoegl (2002) & JIBS & $\mathrm{F}$ & $\mathrm{b}$ \\
\hline Tseng et al. (2007) $\dagger$ & JIBS & $\mathrm{F}$ & $\mathrm{d}$ \\
\hline $\begin{array}{l}\text { Vahlne \& Ivarsson } \\
(2014) \dagger\end{array}$ & JIBS & $\mathrm{F}$ & $\mathrm{e}$ \\
\hline $\begin{array}{l}\text { Van Den Bulcke et al. } \\
\text { (1999) }\end{array}$ & MIR & $\mathrm{F}$ & $\mathrm{e}$ \\
\hline Wan et al. (2015) & GSJ & $\mathrm{C}$ & $\mathrm{c}$ \\
\hline Xia et al. (2018) & GSJ & $\mathrm{F}$ & $\mathrm{a}, \mathrm{b}$ \\
\hline Xu \& Shenkar (2002) $\dagger$ & AMR & $\mathrm{C}$ & $\mathrm{a}$ \\
\hline Young et al. (1996) & MIR & $\mathrm{F}$ & $\mathrm{e}$ \\
\hline Yuan et al. (2016) & JMS & $\mathrm{C}$ & $\mathrm{a}, \mathrm{b}$ \\
\hline $\begin{array}{l}\text { Zaheer \& Mosakowski } \\
\text { (1997) }\end{array}$ & SMJ & $\mathrm{C}$ & c \\
\hline Zahra et al. (2000) & AMJ & $\mathrm{F}$ & $\mathrm{d}$ \\
\hline Zeng et al. (2013a) & MIR & $\mathrm{C}$ & $\mathrm{c}$ \\
\hline Zeng et al. (2013b) & JIBS & $\mathrm{C}$ & $\mathrm{c}$ \\
\hline Zhong et al. (2019) & JIBS & $\mathrm{C}$ & $\mathrm{c}$ \\
\hline Zhou \& Guillén (2015) & SMJ & $\mathrm{F}, \mathrm{C}$ & $\mathrm{a}$ \\
\hline Zhu \& Chen (2015) & ASQ & $\mathrm{F}$ & $\mathrm{d}$ \\
\hline
\end{tabular}

Notes:

1. $\dagger$ articles that cite Penrose (1959), * articles drawn on Penrose's theory

2. AMJ: Academy of Management Journal, AMR: Academy of Management Review, ASQ: Administrative Science Quarterly, GSJ: Global Strategy Journal, JIBS: Journal of International Business Studies, JMS: Journal of Management Studies, JOM: Journal of Management, JWB: Journal of World Business, MIR: Management International Review, OS: Organization Science, SMJ: Strategic Management Journal.

3. F: Facilitators, C: Constraints, T: Growth trajectory

4. a: Foreign market entry, b: Expansion in foreign markets, c: Survival, exit, or divestment, d: International scope and intensity (i.e., multinationality), e: Growth trajectory 